ISBN 978-623-6833-47-6 (PDF)

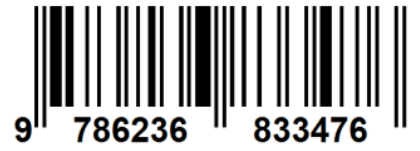

KONSEP SEKOLAH RAMAH ANAK ISLAMI

Dr. Eni Fariyatul Fahyuni, S.Psi, M.Pd.t.

Dr. Nurdyansyah, M.P.

\section{BUKU AJAR}

Universitas Muhammadiyah Sidoarjo

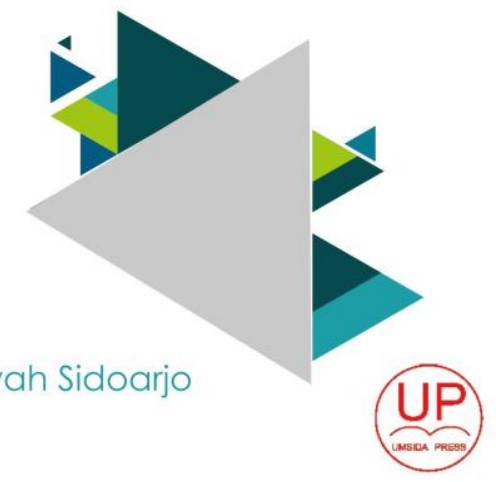

\section{KONSEP SEKOLAH RAMAH} ANAK ISLAMI

Dr. Eni Fariyatul Fahyuni, S.Psi, M.Pd.I. Dr. Nurdyansyah, M.Pd.
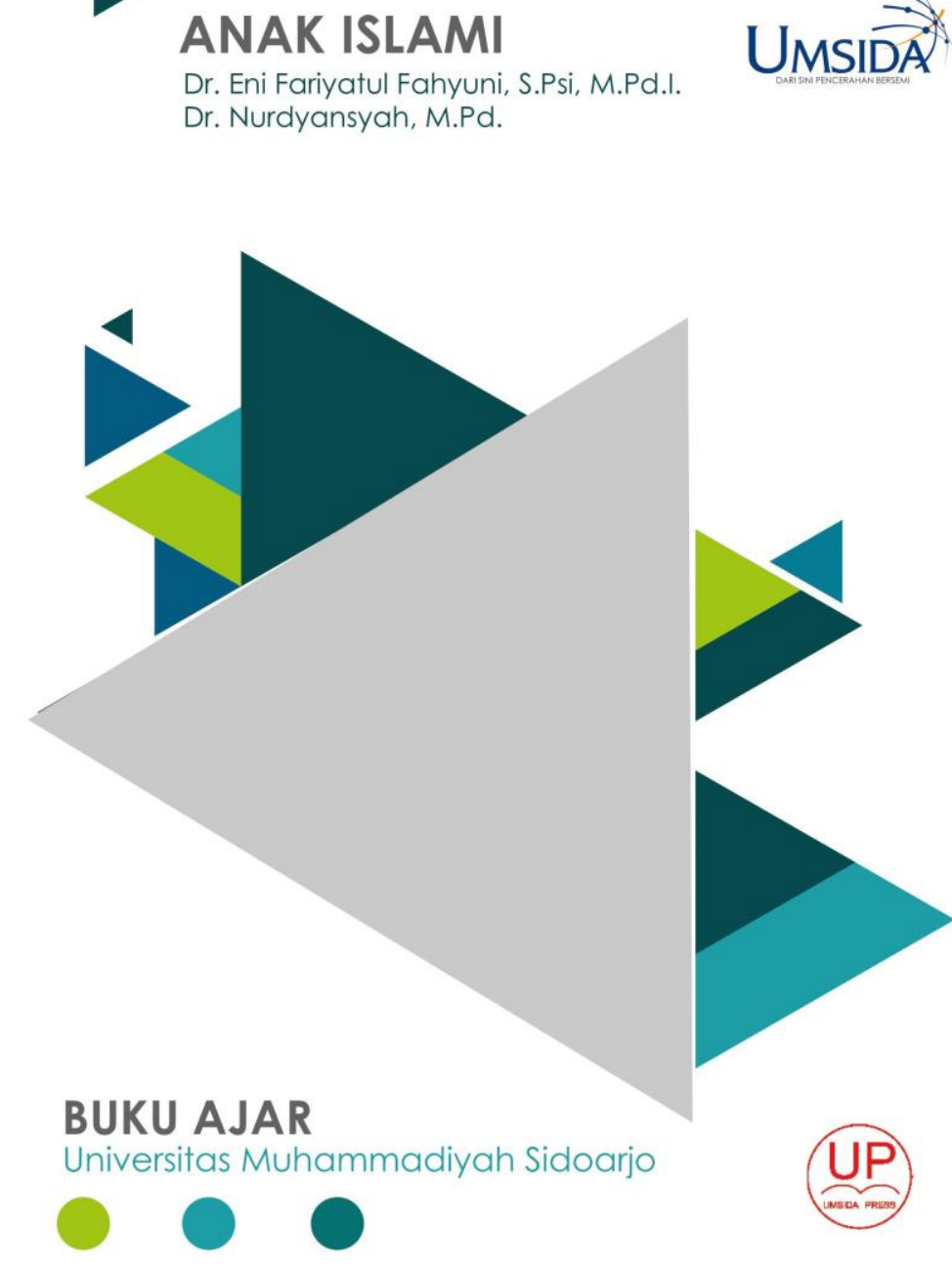


\title{
BUKU AJAR \\ KONSEP SEKOLAH RAMAH ANAK ISLAMI
}

\author{
Penulis \\ Dr. Eni Fariyatul Fahyuni, S.Psi, M.Pd.I \\ Dr. Nurdyansyah, M.Pd
}

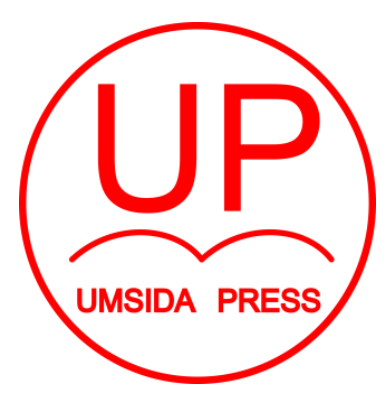

\author{
Diterbitkan oleh \\ UMSIDA PRESS \\ J1. Mojopahit 666 B Sidoarjo \\ ISBN:
}

Copyright@2020.

Authors

All rights reserved 


\section{BUKU AJAR}

KONSEP SEKOLAH RAMAH ANAK ISLAMI

Penulis :

Dr. Eni Fariyatul Fahyuni, S.Psi, M.Pd.I.

Dr. Nurdyansyah, M.Pd.

\section{ISBN :}

978-623-6833-47-6

\section{Editor :}

Dr. Budi Haryanto, M.Pd.

Design Sampul dan Tata Letak :

Mochamad Nashrullah, S.Pd,

Amy Yoga Prajati, S.Kom.

\section{Penerbit :}

UMSIDA Press

Anggota IKAPI No. 218/Anggota Luar Biasa/JTI/2019

Anggota APPTI No.002 0181092017

\section{Redaksi :}

Universitas Muhammadiyah Sidoarjo

Jl. Mojopahit No 666B

Sidoarjo, Jawa TImur

Cetakan pertama, November 2020

(C) Hak cipta dilindungi undang-undang

Dilarang memperbanyak karya tulis ini dengan suatu apapun tanpa ijin tertulis dari penerbit. 


\section{KATA PENGANTAR}

Puji syukur penyusun panjatkan kehadirat Allah Swt atas rahmat, hidayah serta inayahNya buku ajar mahasiswa yang berjudul "Konsep Sekolah Ramah Anak Islami" dapat terselesaikan dengan baik.

Penulis mengucapkan terimakasih yang sebesarbesarnya kepada:

1. Dr. Istikomah, M.Ag selaku Dekan Fakultas Agama Islam yang memberikan arahan dan motivasi kepada penulis dalam menyelesaikan buku ajar

2. Dr. Budi Haryanto, M.Pd selaku Kaprodi Magister Manajemen Pendidikan Islam yang telah memberikan dukungan guna terselesaikannya buku ajar ini

3. Rekan-rekan dosen pengajar pada Mata Kuliah Pengembangan Kurikulum Pendidikan Islam yang berbagi pengalaman dalam mata kuliah tersebut

Saran dan kritik sangat penulis harapkan untuk mewujudkan buku ajar "Konsep Sekolah Ramah Anak Islami" yang lebih baik dan sesuai dengan amanah pemerintah. Amin

Tim Penulis 


\section{DAFTAR ISI}

KATA PENGANTAR

DAFTAR ISI

DAFTAR TABEL

DAFTAR GAMBAR

Bab I. Konsep Pendidikan Ramah Anak......................... 1

A. Pengertian Pendidikan Ramah Anak ..................... 1

B. Sekolah dan Pendidikan Bagi Anak ........................ 4

C. Pola Pendidikan Ramah Anak ............................. 10

D. Pendidikan Ramah Anak Dalam Islam.................. 13

E. Prinsip Penyelenggaraan SRA .............................. 15 SOAL-SOAL

Bab II. Membangun Sosialisasi Pada Anak ..................... 21

A. Bersosialisasi dengan Lingkungan Sekolah ........... 23

B. Membangun Sosialisasi Pada Anak ...................... 28

C. Sekolah, Sarana Aktualisasi dan Potensi Anak...... 30

D. Memantau Kecerdasan Anak ............................... 35 SOAL-SOAL

Bab III Sekolah dan Peluang Masa Depan ...................... 46

A. Sekolah Masa Depan........................................ 46

B. Perlukah Observasi Sekolah? .............................. 50

C. Memilih Sekolah Ramah Anak ............................. 58

D. Mengumpulkan Informasi SRA ........................... 60 SOAL-SOAL

Bab IV Guru Zaman Now ........................................... 70

A. Menjadi Guru Masa Kini.................................... 71

B. Menerapkan Inovasi Belajar Kreatif..................... 72 
C. Menghilangkan Punisment .................................. 75

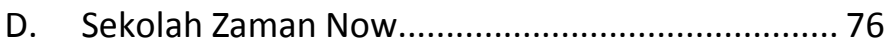

E. Konsep Rumah Tumbuh...................................... 93

SOAL-SOAL 


\section{DAFTAR TABEL}

Tabel 1. Komponen Sekolah Ramah Anak .......................... 32

Tabel 2. Pemetaan kondisi dan Harapan Sekolah............... 106

Tabel 3. Pemetaan Kesenjangan ...................................... 107

Tabel 4. Format Rincian Jadwal Pelaksanaan .................... 108

Tabel 5. Format Perhitungan Anggaran Biaya .................... 109

Tabel 6. Format Pemetaan Alternatif Pemecahan Masalah111 


\section{DAFTAR GAMBAR}

Gambar 1. Dimensi Sekolah Ramah Anak............................. 3

Gambar 2. Potret Pendidikan di Daerah Terpencil ................ 5

Gambar 3. Konsep SRA ................................................ 14

Gambar 4. Membangun Sosialisasi Anak ............................ 29

Gambar 5. Menggali Potensi Siswa.................................... 31

Gambar 6. Kolaborasi Pilar Pendidikan.............................. 32

Gambar 7. Multiple intelegence ..................................... 36

Gambar 8. Sekolah Masa Depan ....................................... 47

Gambar 9. Menggalakkan Program Literasi di Sekolah ........ 72

Gambar 10. Telaah Buku Bagi Siswa ................................... 73

Gambar 11. Mencegah Bulyying ..................................... 75

Gambar 12. Pola Pembelajaran Zaman Now ...................... 77

Gambar 13. Hubungan Antara Premis Tujuan dan Rencana 96 
BATANG TUBUH DAN SUB- CAPAIAN

PEMBELAJARAN MATA KULIAH

\begin{tabular}{|c|c|}
\hline BAB & Sub CPMK \\
\hline \multirow{5}{*}{$\begin{array}{l}\text { Bab 1, Konsep } \\
\text { Pendidikan Ramah } \\
\text { Anak }\end{array}$} & $\begin{array}{l}\text { 1. Pengertian Pendidikan Ramah } \\
\text { AnaK }\end{array}$ \\
\hline & $\begin{array}{l}\text { 2. Sekolah dan Pendidikan Bagi } \\
\text { AnaK }\end{array}$ \\
\hline & 3. Pola Pendidikan Ramah Anak \\
\hline & $\begin{array}{l}\text { 4. Pendidikan Ramah Anak Dalam } \\
\text { Islam }\end{array}$ \\
\hline & 5. Prinsip Penyelenggaraan SRA \\
\hline \multirow{4}{*}{$\begin{array}{l}\text { Bab 2, Membangun } \\
\text { Sosialisasi Pada } \\
\text { Anak }\end{array}$} & $\begin{array}{l}\text { 1. Bersosialisasi dengan } \\
\text { Lingkungan Sekolah }\end{array}$ \\
\hline & $\begin{array}{l}\text { 2. Membangun Sosialisasi Pada } \\
\text { Anak }\end{array}$ \\
\hline & $\begin{array}{l}\text { 3. Sekolah, Sarana Aktualisasi dan } \\
\text { Potensi Anak }\end{array}$ \\
\hline & 4. Memantau Kecerdasan Anak \\
\hline \multirow{4}{*}{$\begin{array}{l}\text { Bab 3, Sekolah dan } \\
\text { Peluang Masa } \\
\text { Depan }\end{array}$} & 1. Sekolah Masa Depan \\
\hline & 2. Perlukah Observasi Sekolah \\
\hline & 3. Memilih Sekolah Ramah Anak \\
\hline & 4. Mengumpulkan informasi SRA \\
\hline \multirow{5}{*}{$\begin{array}{l}\text { Bab 4, Guru Zaman } \\
\text { Now }\end{array}$} & 1. Menjadi Guru Masaa Kini \\
\hline & $\begin{array}{l}\text { 2. Menerapkan Inovasi Belajar } \\
\text { Kreatif }\end{array}$ \\
\hline & 3. Menghilangkan Punisment \\
\hline & 4. Sekolah Zaman Now \\
\hline & 5. Konsep Rumah Tumbuh \\
\hline
\end{tabular}




\section{Bab I. Konsep Pendidikan Ramah Anak}

\section{A. Pengertian Pendidikan Ramah Anak}

Pendidikan ramah anak mendesain lingkungan belajar yang nyaman, aman dan menyenangkan bagi siswa dan guru di sekolah. Pendidikan ramah anak merupakan Pendidikan yang memberikan kemerdekaan siswa dalam belajar (Hermino, 2017). Kemerdekaan belajar yang dimaksud adalah kebebasan siswa dalam mengeluarkan ide, pendapat maupun pemikirannya, kemerdekaan siswa dalam mengembangkan potensi yang dimilikinya tanpa rasa takut dan pembatasanpembatasan lainnya. Pola pendidikan berbasis ramah anak memperlakukan anak sebagai subyek yang punya hak berkarya dan berekspresi sesuai potensinya. Sekolah yang memberikan keleluasaan siswa dalam mengasah dan mengembangkan bakat, minat maupun potensi lainnya yang mereka miliki. Pendidikan ramah anak memberikan dan memperhatikan hak anak dalam belajar, mengembangkan potensi dan selanjutnya menerapkan potensi gtersebut dengan bimbingan guru maupun orang dewasa lainnya (Agbarachi Opara \& Silas Oguzor, 2011).

Dengan demikian untuk mewujudkan sekolah ramah anak tentunya harus sesuai dan mengacu hasil keputusan menuju standar yang berkualitas. Mewujudkan sekolah yang berkualitas adalah sebuah proses dan tentunya membutuhkan dukungan serta kerjasamanya dari berbagai pihak, diantaranya: 1) para pemangku kepentingan (pemimpin) untuk mewujudkan sekolah ramah anak, 2) memperhatikan karakteristik peserta didik dan konteks 
dimana pembelajaran tersebut dilaksanakan, 3) guru memiliki kompetensi dan kemampuan dalam menerapkan sekolah ramah anak, dan 4) tersedianya fasilitas pendukung guna menerapkan pendidikan ramah anak (Orkodashvili, 2013).

Inilah pentingnya menciptakan lingkungan Pendidikan ramah anak agar mereka dapat tumbuh sehat, aktif, menyenangkan, mengeksplorasi, dan mampu bersosialisasi dengan lingkungan sekitar (Leino, 2011). Lingkungan belajar yang ramah anak mampu merangsang keaktifan belajar siswa. Hasil penelitian menunjukkan peran guru sangat penting dalam menerapkan pengajaran berbasis sekolah ramah anak yang tentunya perlu dukungan dari pimpinan dalam hal ini adalah pemangku kepentingan sekolah dan kerjasamanya dengan orangtua dan masyarakat (Zendah, 2018).

Sekolah ramah anak menjamin pengadaan lingkungan belajar yang aman, tentram dan terbuka terhadap perkembangan psikologis peserta didiknya. Untuk itu dinamika kedekatan interpersonal antara guru dan peserta didik berperan penting dalam menghantarkan kesuksesan belajar peserta didiknya (Pennings et al., 2018). Berikut kunci pembentuk konsep yang biasa disebut 5 Dimensi Sekolah Ramah Anak. Penciptaan lingkungan belajar ramah anak dengan memberikan proses pembelajaran yang sesuai dengan hak dan kebutuhan siswa merupakan kunci utama dalam menerapkan pendidikan ramah siswa (Maoto, 2014). 


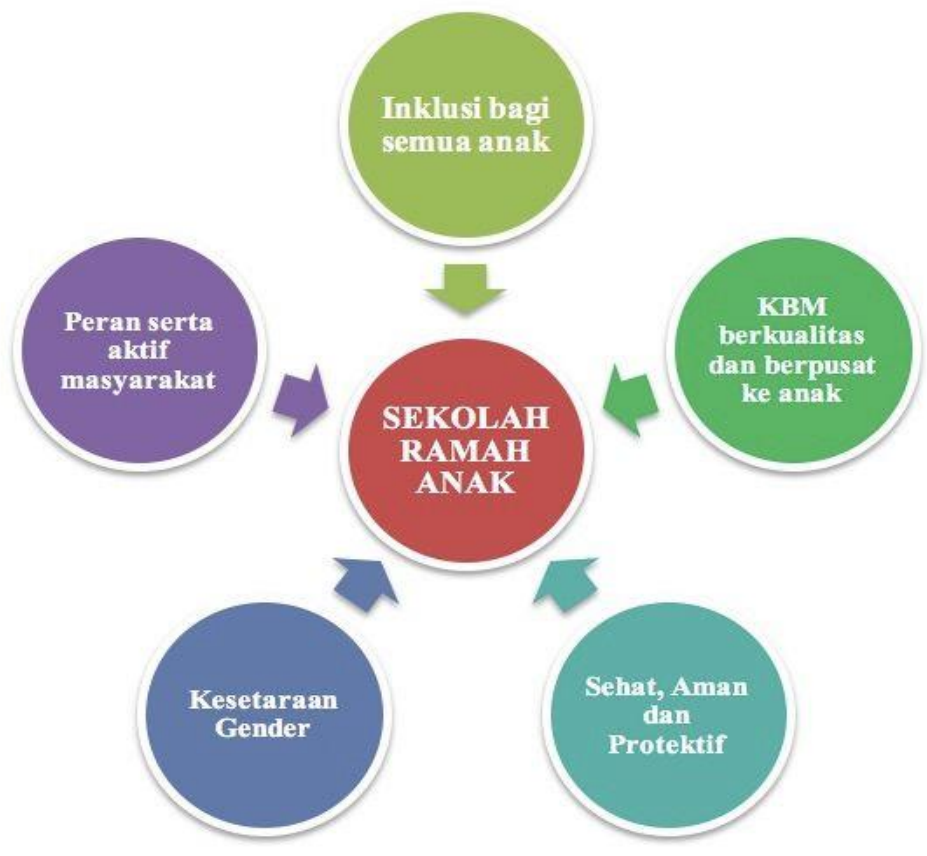

Gambar 1. Dimensi Sekolah Ramah Anak

Untuk itu dalam penerapan sekolah ramah anak perlu adanya dukungan dan kebijakan sekolah yang jelas, terarah dan berkelanjutan guna mengoptimalkan berbagai potensi belajar para siswanya. Salah satu strategi pengajaran yang diterapkan adalah dengan membangun kolaboratif siswa sehingga dapat memberikan pengalaman belajar yang bermakna baginya (Wadjdy, 2017), dengan berkolaboratif menerapkan sekolah ramah anak yang sesuai dengan nilai- 
nilai yang mereka sepakati Bersama (Çobanoğlu, AyvazTuncel, \& Ordu, 2018)

B. Sekolah dan Pendidikan Bagi Anak

Pada sebagian orang, mendidik anak tidak selalu harus diprogram atau disengaja secara kaku di awal, namun lebih memfokuskan agar anak-anak dapat berkembang sesuai dengan usia dan masanya memasuki sekolah. Akan tetapi. Bagi sebagian yang lain, mendidik anak memang seharusnya secara sengaja dan diprogram. Rasulullah SAW. pernah mengibaratkan bahwa mendidik anak di waktu kecil laksana mengukir di atas batu. Artinya, cukup sulit, perlu energi besar, dan kesabaran. Namun,jika berhasil, buahnya tak akan pernah hilang (Saat, 2010). Mendidik anak dengan seadanya apalagi asal jalan merupakan bentuk ketidaksungguhan. Oleh karena itu. hindarkanlah mendidik anak dengan pola seadanya, cenderung asal masuk dan lulus sekolah, padahal boleh jadi inilah awal dan bentuk ketidaksungguhan orang tua.

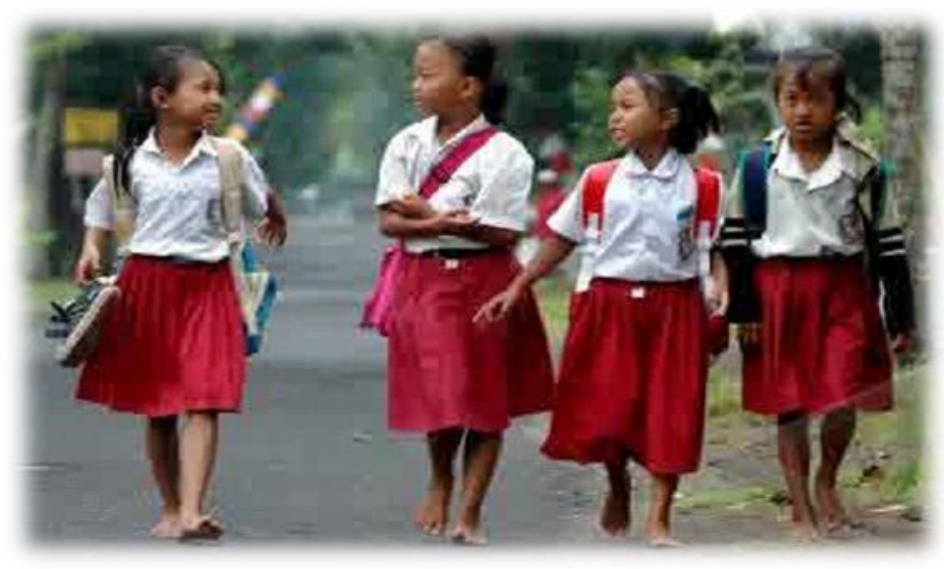


Gambar 2. Potret Pendidikan di Daerah Terpencil

\section{Mengapa Harus Sekolah?}

Pendapat klasik tentang sekolah hanya sebagai tempat untuk mencari ilmu pengetahuan yang bertujuan mendapat selembar ijazah, tampaknya sudah bukan zamannya lagi. Istilahnya, "Hari gini, gak sekolah, gak gaul lagi," dianggap sebagai tren yang terus berkembang. Terlebih, jika melihat sekolah merupakan tempat kedua untuk mendidik anak setelah keluarga. Kecenderungan untuk menilai sekolah hanya berorientasi pada uang tanpa menyeimbangkan kualitas pengajaran dan mutu pendidikan tidak pantas dipandang sebelah mata oleh hanyak orang lagi. Hal ini dikarenakan saat ini sekolah merupakan tempat kita yang benar-benar dipersiapkan agar anak siap terjun di masyarakat (Nuraeni, Andrisyah, \& Nurunnisa, 2019). Sekolah juga dapat dijadikan media bersosialisasi dengan warga sekolah yang lain. Sekolah juga merupakan salah satu sarana membina putra-putri bangsa agar menjadi anak-anak yang berguna bagi bangsa dan negara. Oleh karena itu, banyak sekolah yang berdiri, baik di desa maupun di kota dengan keunikannya masing-masing. Al Quran menjelaskan betapa pentingnya Pendidikan. Islam telah mendorong pentingnya literasi dan pendidikan bagi manusia dalam Q.S al Mujadilah, 58: 11 (RI, 2012).

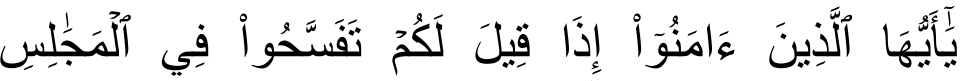

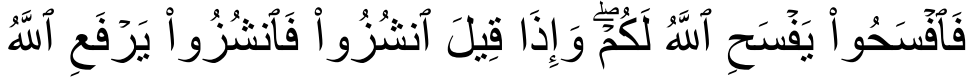




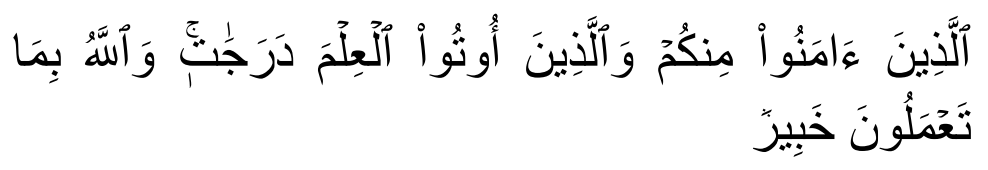

".............Allah akan meninggikan orang-orang yang beriman di antaramu dan orang-orang yang diberi ilmu pengetahuan beberapa derajat"

Ayat di atas mempertegas bahwa dengan ilmu pengetahuan seseorang akan mendapatkan tempat kemuliaan. Oleh karenanya pendidikan memegang peranan yang sangat penting dalam pembentukan manusia, guna membentuk kepribadian manusia yang berakhlak mulia sebagai manifestasi sebagai manusia individu dan social yang mengabdikan diri kepada Tuhannya. Pendidikan dalam pandangan Islam dimaksudkan untuk peningkatan potensi spiritual dan membentuk peserta didik agar menjadi manusia yang beriman dan bertakwa kepada Tuhan Yang Maha Esa dan berakhlak mulia. Akhlak mulia mencakup etika, budi pekerti, dan moral sebagai perwujudan dari tujuan Pendidikan.

2. Peran dan Kerja Sama Orang tua dengan Sekolah

Sejak masa kanak-kanak, orang tualah orang yang sangat mengetahui fase demi fase pembinaan keilmuwan dan pemikiran.Bahkan, hanya orang tua yang bisa rncndeteksi kelebihan dan kekurangan anaknya sejak dan dalam kandungan terutarna emosional anak. Peran orang tua sejak mengandung ini bisa membeni dampak positif dan negatif bagi kelangsungan kehidupan dan masa depan anak. Pada masa ini daya tangkap dan daya serap otak mereka 
berada pada kemampuan maksimal; pemahaman dan hal yang terkecil hingga yang besar mulai merasuki dada mereka. Abu Hurairah r.a. meriwayatkan secara marfu' bahwa Rasulullah saw. bersabda, "Barangsiapa yang mempelajari Al-Qur 'an ketika masih muda, Al-Qur 'an itu akan menyatu dengan daging dan darahnva. Siapa yang mempelajarinya ketika dewasa. sedangkan ilmu itu akan lepas darinya dan tidak melekat pada dirinya maka ia mendapaikan pahala dua kali." (HR Baihaqi, Dailani, dan Hakim)

Seiring mengenal bagaimana hakikat dan tugas sebagai orang tua, tentu kita pun tidak ingin terjebak oleh pola pikir mendidik anak seadanya, kan? Rasulullah SAW. sangat menaruh harapan besar kepada anak-anak. Bagi beliau, kehadiran anak - anak adalah penerus perjuangan agama Allah. Oleh karena itu, perlu banyak contoh nyata yang langsung bisa dialami anak dalam mengenalkan Allah dan Rasul-Nya (Sholeh, 2018). Berikut ini beberapa alasan sebab anak-anak kita harus sekolah.

a) Sekolah membantu para orang tua, khususnya orang tua, sehingga dapat mengarahkan anak untuk melangkah menuju ilmu, belajar, serta mencintai ilmu dan ularna. Demikian juga, mencintai dan takut kepada Allah SWT, Sang Pencipta. Cinta dan takut kepada Allah akan memunculkan sikap konsisten dalam mencari ilmu tanpa bosan dan dihinggapi rasa putus asa.

b) Melaiui sekolah sedari dini memudahkan orang tua untuk menanamkan prinsip menuntut ilmu adalah perintah dari Allah SWT. 
c) Sekolah membantu orang tua menyeimbangkan karakter pendidikan di rumah dengan pendidikan formal yang juga bertujuan dan mengacu pada pembentukan karakter, tabiat, tingkah laku, atau akhlak yang mulia. Pembentukan karakter dan akhlak yang mulia tersebut merupakan tujuan luar biasa dan sistern pendidikan yang benar.

d) Sekolah memudahkan para orang tua, khususnya orang tua. untuk menerapkan konsep pendidikan yang lengkap dan seimbang antara pendidikan jasmani, pendidikan mental, dan pendidikan rohani yang terprograrn dan terencana.

e) Sekolah sebagai tempat pendidikan anak secara formal yang berarti pendidikan di ruang kelas. Ruang kelas dimaksud bukan hanya sekadar di sekolah, melainkan juga bisa masjid atau bahkan rumah. Bisa bersama-sama dengan orang lain atau khusus anak-anak kita sendiri. Misalnya, melihatkan anak bersama ke masjid. Ajak sesekali mereka di acara pengajian ayah atau orang tuanya. Meskipun mungkin mereka belum mengerti, tanpa kita sadari mereka akan mendarahdagingkan sikap dan perjuangan ayah dan orang tuanya untuk mencintai Allah SWT dan Rasulullah saw.

f) Sekolah yang dilakukan secara rutin di rumah atau home schooling memudahkan orang tua untuk menjaga perannya sebagai pengasuh dan sekaligus pendidik. Di rumah yang juga sekolah, lebih dimungkinkan menyimpan banyak buku referensi membaca dan 
menambah ilmu, selain belajar secara otodidak bersama orang tua.

g) Sekolah memberi inspirasi bagi orang tua untuk memilih pendidikan yang sesuai dengan ajaran agama dan metode belajar yang benar pula.

h) Sekolah membantu orang tua mempelajari sesuatu secara mendalam hingga dipahami apa yang dipelajari dengan benar yang tidak semua bisa didapatkan di rumah.

i) Sekolah membantu orang tua meyakini ilmu yang sedang dipelajari di sekolah sehingga bisa dijadikan dasar untuk berbuat atau mempraktikkannya di rumah.

j) Sekolah memudahkan anak-anak untuk menerapkan sesuatu yang dipelajari bersifat praktis, bukan sekadar teoretis sehingga dapat menyelesaikan suatu masalah.

k) Sekolah mengajarkan kemandirian pada diri anak meskipun cara anak mandiri yang dituntut di sekolah tentu berbeda dengan tuntutan di rumah. Yang akan menjadi persoalan adalah apabila sang anak di rumah masih sangat bergantung kepada orang terdekatnya, baik ayah orang tuanya, pengasuhnya, maupun orang-orang yang menjadi anutannya. Bersama pendidik di sekolah, anak akan mulai berlatih menghilangkan kesan sulit menjalankan program-program individu di sekolah, seperti pergi ke kamar kecil, menalikan sepatu, atau mengerjakan tugas-tugas di sekolah. Setidaknya anak dalam melakukan aktivitas dapat menyesuaikan diri dengan tuntutan lingkungan sebayanya. 
I) Kerja sama sekolah dan pendidikan di rumah memberikan anak dua guru yang bisa menjadi cermin sehingga akan membekas di dalam jiwa dan pikiran mereka.

m) Orang tua berperan paling besar untuk melihat siapa guru yang terbaik yang mengajarkan anak-anaknya berbudi pekerti baik. Jika diingat bahwa bcrsungguhsungguh di dalam memilihkan guru dan pendidik bagi anak, sama halnya dengan kesungguhan di dalam memilihkan orang tua dan orang tua susuan baginya, bahkan lebih dan itu. Seorang anak akan mengambil akhlak, gerak-gerik, adab, dan kebiasaan dan gurunya melebihi yang diambil dan orang tuanya sendiri.

n) Sekolah menjadi simulasi keberhasilan anak dalam bergaul. kemampuan jiwa kepemimpinan, dan keberanian yang diajarkan oleh pendidikan dasar di rumah.

o) Sekolah mengasah anak untuk fokus pada tujuan masa depanya dan mengarahkannya pada langkah-langkah strategis yang lebih mudah bagi anak untuk memahami setiap masalah yang ia hadapi di sekolah dan di rumah.

C. Pola Pendidikan Ramah Anak

Konsep sekolah ramah anak telah lama dicanangkan guna menekankan pada hak anak untuk mendapatkan pendidikan yang berkualitas dan juga dapat membantu anakanak untuk belajar sesuai dengan apa yang mereka butuhkan (Çobanoğlu et al., 2018). Mengembangkan sekolah ramah 
anak membutuhkan kerjasama dari para guru, kepala sekolah, orangtua, dan masyarakat guna meningkatkan kualitas pendidikan di sekolah (Hermino, 2017) yang terintegrasi dengan nilai-nilai Islam untuk memotivasi siswa mengubah cara berpikir dan sikap mereka (Purwati, Zubaidah, Corebima, \& Mahanal, 2018).

Pola pendidikan ramah anak adalah pola pendidikan yang tidak bertentangan dengan Q.S. Al Furqon ayat 74, yang menjelaskan unsur penting dalam pendidikan (RI, 2012).

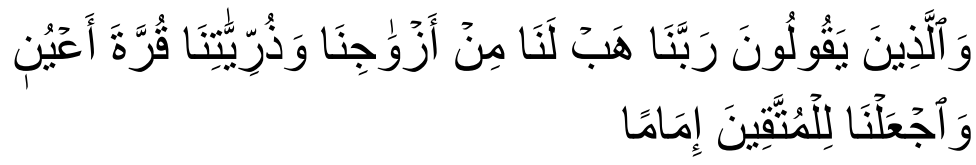

"Dan orang-orang yang berkata dalam berdoa kepada Rabb mereka, "Wahai Rabb kami, anugerahkanlah kepada kami dari istri-istri dan anak-anak kami orang yang bisa menjadi penyejuk hati kami karena ketakwaan dan keistikamahannya di atas kebenaran, dan jadikanlah kami sebagai imam bagi orang-orang yang bertakwa dalam kebenaran, serta sebagai teladan bagi orang lain"

Q.S. Al Furqon ayat 74 di atas menjelaskan bahwa Pendidikan yang diberikan tidak memudarkan kedudukan anak sebagai Qurrota A'yun (penyejuk mata). Meskipun bermain merupakan hak anak, namun tidak lantas menafikan tujuan dan unsur penting dalam pendidikan itu sendiri. Hal ini diperkuat pada Q.S. Al Baqarah ayat 132-133 (RI, 2012). 


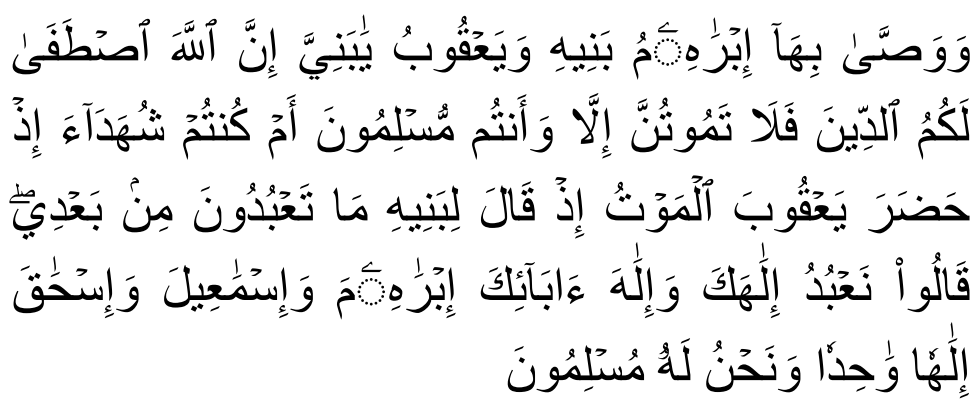

"Dan Ibrahim telah mewasiatkan ucapan itu kepada anak-anaknya, demikian pula Ya'qub. (Ibrahim berkata): "Hai anak-anakku! Sesungguhnya Allah telah memilih agama ini bagimu, maka janganlah kamu mati kecuali dalam memeluk agama Islam. Adakah kamu hadir ketika Ya'qub kedatangan (tanda-tanda) maut, ketika ia berkata kepada anak-anaknya: "Apa yang kamu sembah sepeninggalku?" Mereka menjawab: "Kami akan menyembah Tuhanmu dan Tuhan nenek moyangmu, Ibrahim, Ismail dan Ishaq, (yaitu) Tuhan Yang Maha Esa dan kami hanya tunduk patuh kepadaNya".

Allah SWT menggambarkan kekhawatiran Nabi-Nabi sebelumnya mengenai kondisi keagamaan anak-anaknya kelak, hingga ketika maut tepat berada di kerongkongan Nabi Yakub pun, la masih menyempatkan diri untuk memastikan siapa yang kelak disembah oleh anaknya. Barangkali inilah inti dari tujuan pendidikan dalam Islam, yakni memastikan fitrah anak tetap terjaga tanpa harus menghilangkan hak bermain. 


\section{Pendidikan Ramah Anak Dalam Islam}

Sekolah secara etimologi (bahasa) diambil dari bahasa latin, yaitu skhole, scola, scolae, atau skhola yang memiliki arti waktu luang atau waktu senggang. Pengertian tersebut bukan tanpa alasan, karena pada awalnya kegiatan sekolah hanya untuk melengkapi kegiatan utama anak-anak yakni bermain. Inilah yang dimaksud oleh Allah SWT dalam Q.S. Asy Syam ayat 8 yang menyebutkan bahwa setiap anak manusia diberikan ilham taqwa (RI, 2012).

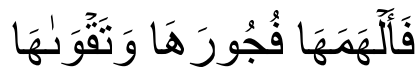

"Maka Allah mengilhamkan kepada jiwa itu (jalan) kefasikan dan ketakwaannya"

Namun yang jadi pertanyaan, bisakah tujuan tersebut tercapai, jika anak datang ke sekolah dengan memikul dogma social, bahwa tugas anak hanyalah melulu belajar, agar kelak mendapatkan selembar ijazah. Akibat hal tersebut kini sekolah tidak lagi ramah dengan anak, kalaupun anak datang kesekolah tidak lain hanya karena merasa terseret oleh jerat obsesi duniawi orang tua. Alih-alih untuk meraih masa depan yang cerah dan sukses, anak ditempa layaknya besi, mereka dituntut mengikuti bentuk pembelajaran yang diinginkan, hingga akhirnya pendidikan terkesan jauh dari nilai kemanusiaan. 


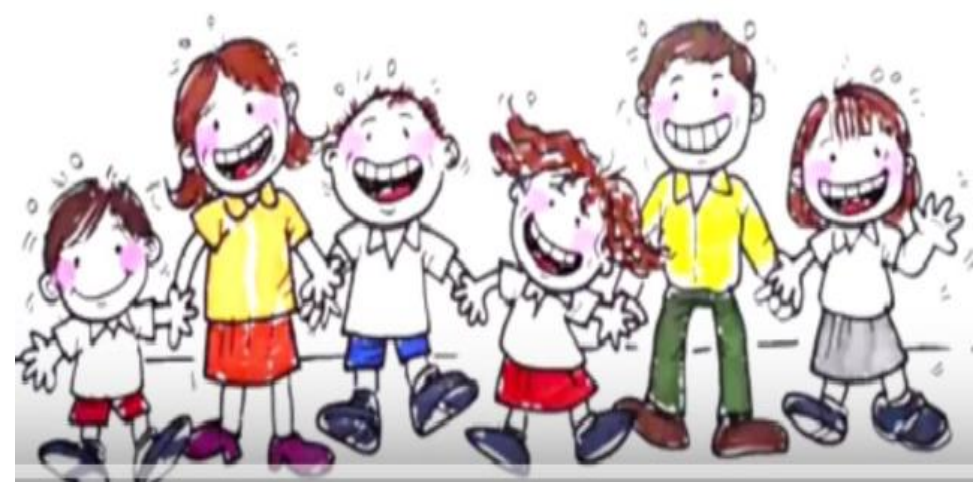

Gambar 3. Konsep SRA

Konsep sekolah ramah anak (SRA) ialah sekolah yang menghadirkan sudut senyum bagi setiap anak, mereka yang datang ke sekolah atas dasar hati yang senang. Baik kaya mau pun miskin, cepat atau lambat kemampuan ia menghafal, namun gerbang dan pintu sekolah tetap terbuka lebar menyambut amanat-amanat Allah SWT tersebut.

Sekolah ramah anak, bukan berarti sekolah yang menumbuh kembangkan budaya permisif (bebas), bukan pula sekolah yang membenarkan sepenuhnya konsep pendidikan kontemporer yang melarang penggunaan kata "jangan" dengan dalih menghambat kreatifitas anak (Lin, 2012). Islam tidak mengenal kebebasan absolut, dan Islam pun sangat erat dengan syariat bernada larangan. Karena, jika anak tidak diperkenalkan dengan kata "jangan", maka ia akan tumbuh menjadi pribadi yang bias untuk memastikan mana yang halal dan mana yang haram. Sekolah ramah anak 
berada diantara kedunya, anak-anak diberi kebebasan untuk mencari kemudahan dalam usaha memahami pelajaran, namun tetap mempertimbangkan dimensi etis dan kedisiplinan (Hermino, 2017).

\section{E. Prinsip Penyelenggaraan SRA}

Sekolah Ramah Anak diselenggarakan untuk memberikan jaminan kepada peserta didik berupa situasi aman, bersih, sehat, peduli, dan berbudaya, dengan menciptakan lingkungan dan suasana kehidupan sekolah yang menyenangkan, pemenuhan hak dan perlindungan peserta didik dari kekerasan, tindakan diskriminatif dalam belajar, serta melibatkan peserta didik sebagai (student oriented) dalam perencanaan, kegiatan pembelajaran bahkan aktifitas evaluasi pembelajaran. Sehingga paradigma SRA tidak hanya sebatas membangun sekolah baru, tetapi mendesain situasi dan lingkungan sekolah menjadi nyaman, tenang bahkan aman bagi peserta didik karena sekolah pada dasarnya merupakan "second house" bagi peserta didik setelah rumahnya sendiri

Penyelenggaraan sekolah ramah anak harus didasarkan pada prinsip dasar, yaitu :

1. Merdeka belajar yakni memberikan kemerdekaan belajar kepada peserta didik untuk menikmati hak pendidikannya tanpa diskriminasi apapun.

2. Menjadikan peserta didik sebagai pemeran utama pendidikan (student centre) sehingga semua kebijakan pendidikan harus dimuarakan atas kepentingan peserta didik. 
3. Menciptakan suasana sekolah yang menjunjung tinggi hasrat dan martabat peserta didik sebagai manusia yang harus berkembang sesuai bakat dan kompetensinya masing - masing.

4. Memberikan kesempatan bagi peserta didik untuk terlibat aktif dalam kegiatan perencaan, penyelenggaran maupun pengembangan suasana dan lingkungan pendidikan.

5. Manajemen pengelolaan harus dilaksanakan secara transparan, akuntable, terbuka untuk umum / masyarakat serta berdasarkan hukum yang sudah ditetapkan.Hal penting yang harus diperhatikan dalam penyelenggaraan sekolah ramah anak adalah sebagai berikut:

a. Kebijakan Resmi, bahwa jaminan akan layanan pendidikan dan perlindungan anak didik harus terulis dalam kebijakan resmi lembaga satuan pendidikan.

b. Menyelenggarakan kegiatan pembelajaran berbasis ramah anak.

c. Menyediakan sarana dan prasarana pembelajaran berbasis ramah anak.

d. Pendidik dan tenaga kependidikan yang professional.

e. Mengutamakan partisipasi aktif peserta didik.

f. Melibatkan para alumni, wali siswa, masyarakat, dan lembaga-lembaga sosial kemasyarakatan, dunia usaha serta pemangku kepentingan lainnya 


\section{KESIMPULAN}

Sekolah Ramah Anak dalam prose pembelajarannya memberikan jaminan kepada peserta didik berupa situasi aman, bersih, sehat, peduli, dan berbudaya, dengan menciptakan lingkungan dan suasana kehidupan sekolah yang menyenangkan, pemenuhan hak dan perlindungan peserta didik dari kekerasan, tindakan diskriminatif dalam belajar, serta melibatkan peserta didik sebagai dalam perencanaan, kegiatan pembelajaran bahkan aktifitas evaluasi pembelajaran.

Mengembangkan sekolah ramah anak membutuhkan kerjasama dari para guru, kepala sekolah, orangtua, dan masyarakat guna meningkatkan kualitas kompetensi yang dimiliki oleh para peserta didiknya di masa mendatang. 


\section{SOAL-SOAL}

1. Jelaskan definisi sekolah ramah anak yang anda ketahui?

2. Mengapa penting menyelenggarakan pendidikan berbasis sekolah ramah anak?

3. Bagaimana pola pembelajaran ramah anak?

4. Bagaimana konsep sekolah ramah anak dalam perspektif Islam?

5. Sebutkan 4 (empat) prinsip dasar pada penyelenggaraan sekolah ramah anak? 


\section{DAFTAR PUSTAKA}

Orkodashvili, M. (2013). Quality Education through ChildFriendly Schools: Resource Allocation for the Protection of Children's Rights. SSRN Electronic Journal, 5(1), 101109. https://doi.org/10.18662/rrem/2013.0501.07

Pennings, H. J. M., Brekelmans, M., Sadler, P., Claessens, L. C. A., van der Want, A. C., \& van Tartwijk, J. (2018). Interpersonal adaptation in teacher-student interaction. Learning and Instruction, 55, 41-57. https://doi.org/10.1016/j.learninstruc.2017.09.005

Purwati, N., Zubaidah, S., Corebima, A. D., \& Mahanal, S. (2018). Increasing Islamic Junior High School students learning outcomes through integration of science learning and Islamic values. International Journal of Instruction, 11(4), 841-854. https://doi.org/10.12973/iji.2018.11453a

RI, K. A. (2012). Al Qur'an Terjemah (T. S. Qur'an, ed.). Bandung: Syaamil Qur'an.

Saat, S. (2010). Pendidikan Anak Dalam Al Qur'an. Lentera Pendidikan, 13(1), 64-77.

Wadjdy, F. (2017). Education in Border Regions. TARBIYA: Journal of Education in Muslim Society, 4(2), 224-231. https://doi.org/10.15408/tjems.v4i2.6982

Zendah, K. (2018). Exploring School-Based Stakeholder Support for Teachers in the Promotion of Child-Friendly School Environments Abstract : International Journal of Innovative Research \& Development, 7(6), 162-171.

Pennings, H. J. M., Brekelmans, M., Sadler, P., Claessens, L. C. A., van der Want, A. C., \& van Tartwijk, J. (2018). Interpersonal adaptation in teacher-student interaction. 
Learning and Instruction, 55, 41-57. https://doi.org/10.1016/j.learninstruc.2017.09.005

Purwati, N., Zubaidah, S., Corebima, A. D., \& Mahanal, S. (2018). Increasing Islamic Junior High School students learning outcomes through integration of science learning and Islamic values. International Journal of Instruction, 11(4), 841-854. https://doi.org/10.12973/iji.2018.11453a

RI, K. A. (2012). Al Qur'an Terjemah (T. S. Qur'an, ed.). Bandung: Syaamil Qur'an. 


\section{Bab II. Membangun Sosialisasi Pada Anak}

Bersosialisasi merupakan fitrah dasar manusia. Disebut fitrah karena pada dasarnya bersosialisai merupakan sifat dasar yang dibangun untuk saling mengenal terutama dari anak-anak yang masih belia. Ciri-ciri yang ditimbulkan secara refleks ketika saling mengenal inilah menunjukkan kita sangat tidak mungkin tidak saling kenal antara satu dan yang lain. Sifat dasar inilah memang awalnya. Lihatlah anak-anak kita saat dibawa ke sebuah pertemuan dan ada anak-anak lain di sana. Meskipun baru pertama kali bertemu, mereka akan saling berinteraksi secara perlahan. Tentu saja bahasa sosialisasi mereka khas anak-anak. Bisa dengan berbagi makanan, berlarian, atau sekadar duduk dan bermain bersama. Percakapan biasanya akan bergulir setelah beberapa lama. Hal ini bergantung pada karakter anak. Terlepas dan itu semua sosialisasi juga berdampak pada perkembangan anak-anak kita. Pengaruh yang paling terlihat adalah bahasa dan sikap. Saat anak-anak bergaul dengan teman-teman yang biasa berkata baik, bahasa mereka biasanya terbentuk menjadi baik. Namun, bersiaplah saat anak-anak bergaul dengan teman yang biasa berkata kotor dan kasar, mereka pun berpotensi untuk terbiasa berkatakata yang sama.

Sungguh hal yang logis jika salah satu kunci sukses hidup bermasyarakat adalah kemampuan untuk bersosialisasi. Artinya, jika kita ingin anak kita terampil 
bersosialisasi, pembelajaran sebaiknya dilakukan sejak usia di. Sederhana, bukan? Dalam istilah lain, dengan bersosialisasi, banyak hal yang bisa anak-anak pelajari, seperti sikap saling berbagi, toleransi, dan empati. Seperti harapan para orang tua dan orang tua, anak-anak yang mampu bersosialisasi diharapkan akan tumbuh menjadi anak-anak yang merasa aman dan tenteram jika berada di tengah-tengah lingkungannya. Mengingat hal ini sangat diperlukan untuk mengoptimalkan tumbuh kembang anak. Meskipun demikian, mengingat usia anak yang masih dini, saat fokus anak sebagian besar masih berada pada diri sendiri, sangat diperlukan peran orang tua dalam mendorong dan mengajak anak untuk bersosialisasi dengan lingkungan sekitarnya. Al Qur'an mengajarkan pentingnya manusia untuk saling mengenal yakni sebuah pelajaran hidup yang mendasar bahwa manusia merupakan makhluk pribadi dan social yang saling terkait satu dengan lainnya. Q.S. Surah Al Alaq ayat 2 (RI, 2012).

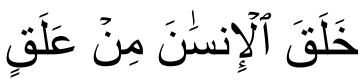

"Dia telah menciptakan manusia dari segumpal darah"

Ayat di atas menjelaskan abhwa manusia diciptakan Allah dari al-Alaq. yang berarti sesuatu yang tergantung. Memang, salah satu periode dalam kejadian manusia saat berada dalam rahim orang tua adalah ketergantungan hasil pertemuan sperma dan ovum yang membelah dan bergerak menuju dinding rahim lalu bergantung atau berdempet dengannya. Yang berdempet itu dinamai zigote oleh pakarpakar embriologi. 
Kata 'Alaq dapat juga berarti ketergantungan manusia kepada pihak lain. la tidak dapat hidup sendiri. Kehendak dan usaha manusia hanyalah sebagian dari sebab-sebab guna memperoleh apa yang di dambakan, sedang sebagian lainnya yang tidak terhitung banyaknya berada di luar kemampuan manusia. Apa yang didambakan itu tidak dapat tercapai kecuali jika sebab-sebab yang lain itu terpenuhi semuanya dan bergabung dengan sebab-sebab yang berada dalam jangkauan upaya manusia. Ini merupakan keniscayaan dan keterpaksaan yang tidak dapat dielakkan setiap makhluk.

\section{A. Bersosialisasi dengan Lingkungan Sekolah}

Sosialisasi pertama biasanya dengan membaca bagaimana sekolah yang akan anak kita masuki. Pada dasarnya jika ditinjau dari orang atau lembaga yang mendirikannya, kita bisa memilih sekolah negeri (yang didirikan oleh pemerintah) atau sekolah swasta (yang didirikan oleh pihak swasta). Kedua sekolah ini jelas mempunyai kualitas dan biaya yang berbeda. Sekolah swasta unggulan lebih mahal dibandingkan dengan sekolah negeri. Namun, ada pula sekolah swasta nonunggulan untuk kalangan menengah ke bawah. Hal itu terjadi karena sekolah swasta menggaji para karyawannya tanpa dibantu oleh siapa pun termasuk pemerintah, sedangkan sekolah negeri, sebaliknya. Nah, di sanalah kita bisa mulai membimbing anak kita untuk membaca lingkungan untuk pertama kalinya dalam bersosialisasi.

Selain rumah, tentu saja melalui orang tua khususnya orang tua perlu dikenalkan kepada anak lebih jauh tentang 
keadaan lingkungan di luar rumah dan sekitar sekolah. Walaupun tugas ini adalah tugas ayah dan orang tua. faktor orang tua kerap kali menjadi bagian yang tak terpisahkan dan perkenalan anak pada Lingkungan sekolahnya. bisa kita bayangkan, sebagian besar anak sekolah mulai pre-school hingga kelas satu SMP masih ditemani oleh sang orang tua meskipun ada yang hanya mengantar dan menjemput di sekolah. Semua ini perlu diketahui agar anak untuk memiliki wawasan mengenai lingkungan sekitar yang dapat membantunya dalam beradaptasi.

Bagaimana peran orangtua dalam mengenalkan lingkungan sekolah pada anak. Berikut ini beberapa hal penting yang harus kita ketahui bersama.

1. Berjalan-jalan di sekitar rurnah dan sekolah.

Sambil berjalan kita dapat memperkenalkan anak kepada orang-orang yang kita kenal, yang kebetulan kita jumpai. Selain itu, kita juga dapat menunjukkan benda-benda, seperti pohon, bunga, mobil, atau motor yang ada di Sepanjang jalan agar anak lebih mengenal Situasi sekelilingnya.Tidak terkecuali untuk anak yang sekolah di play group atau TK, orang tua seharusnya melihat dengan saksama bagaimana kondisi sekolah Nyaman atau tidak bagi kita untuk mengajak anak sambil bercengkerama menikrnati lingkungan sekitar sekolah (Aritonang, Hastuti, \& Puspitawati, 2020). Pengenalan lingkungan sambil bercengkerama ini merupakan bagian däri pengenalan lingkungan yang berpengaruh pada diri anak ketika di dalam kelas. Biasanya anak akan terbawa ceria jika di perjalanan ada yang membuatnya tertarik. Pada 
anak yang mulai masuk sekolah dasar, tepatnya anak kelas satu hingga kelas tiga masih dilakukan antarjemput. Proses pengenalan lingkungan ini mulai dilakukan dengan cara bercakap-cakap meminta pendapat mereka tentang suatu hal, atau menjawab pertanyaan mereka mengenai hal-hal yang mereka temui, terutama menjelaskan tentang sekolah. Misalnya, apa saja yang bisa dijumpai di sekolah. Kalau perlu, ajaklah anak mengunjungi sekolahnya sebelum anak mulai masuk sekolah. Dengan memperkenalkan anak pada lingkungannya diharapkan anak tidak akan merasa canggung berada di tengah-tengah lingkungannya.

2. Mengenalkan aturan-aturan sosial.

Kita perlu membekali anak dengan pengetahuan mengenai aturan-aturan sosial. Sebut saja, kalau anak kita merebut mainan teman, kita bisa mengajarkan 'minta maaf'. Apabila ingin memakai barang teman, kita bisa ajarkan dengan meminta izin, dan sebagainya. Setidaknya kita bisa menggunakan alat bantu cerita kalau kisah dari negeri dongeng, baik dari buku maupun langsung rnenceritakannya (Lin, 2012). Kisah-kisah bertema persahabatan atau film-film yang memberikan pelajaran mengenai aturan-atunan sosial. Aturan-aturan sosial sederhana lainnya adalah dengan cara mengobservasi dan meniru ayah orang tuanya. Misalnya, bagaimana orang tua dan ayahnya memanggil masingmasing nama anaknya, bagaimana ayah dan orang tua menyapa saat bertemu dengan tetangga, bagaimana cara bersikap sopan dan ramah pada saat menerima tarnu, 
dan bagaimana orang tua tidak begitu saja masuk ke rumah tetangga tanpa mengetuk pintu atau mengucapkan salam. Hal-hal ringan yang tanpa kita sadari bisa memberikan nilai berharga dalam benak anak-anak kita. Oleh karena itu, jika ada orang tua yang suka bergaul, supel, dan peka terhadap aturan sosial, akan menjadi model yang baik bagi anak untuk belajar bersosialisasi sehingga besar kemungkinan kelak anak akan berhasil dalam membina hubungan dengan orang lain. Jika ada ayah yang peka terhadap sikap tolongmenolong dan menghargai, kelak anak pun akan menghormati para leluhur-leluhurnya.

3. Praktik bergaul.

Memberi anak kesempatan bergaul dan mempraktikkan keterampilan sosialnya bukanlah hal yang sulit untuk kita lakukan. Bahkan, kita bisa melihat secara langsung melihat hubungan sebab-akibat antara tingkah laku dan konsekuensinya. Misalnya, bagaimana anak berkenalan dengan terlebih dahulu menyebutkan nama dan tempat kita berasal. Begitu pula, jika kita mengajak anak berkunjung ke rumah saudara atau kenalan orang tua, hal ini juga dapat membantu anak untuk mulai berinteraksi dengan orang lain. Dengan demikian, diharapkan anak lebih dapat memahami perilakuperilaku mana yang bisa dan mana yang tidak bisa diterima orang lain. Hal ini biasanya dapat menjadi momen tepat agar anak mulai belajar mempraktikkan keterampilannya dalam menjalin hubungan dengan orang lain. Bagaimana dengan anak kita yang cenderung 
pemalu dan memang sulit untuk diajak bergaul? Pada tahap awal tentu observasilah bagaimana pribadi anak kita sebenarnya. Apakah hanya di sekolah atau juga di rumah. Jika di sekolah, sudah sepantasnya kita libatkan guru di sekolah. Jika di rumah, cobalah obervasi adakah perubahannya ketika kita undang anak lain yang lebih muda sehingga memberikan kesempatan kepada anak kita untuk menjadi pemimpin. Anak usia 3-4 tahun. kemampuan sosial anak berkembang pesat. Keberadaan teman-teman bermain yang seumur memungkinkan mereka saling membantu, seperti bersama-sama menyelesaikan puzzle atau bermain fantasi terbukti mampu menumbuhkan tingkat kepedulian anak. Dalam usia ini pula muncul pertemanan unik seperti saling pandang. melempar senyum, dan meniru perilaku. ini pun bagian dan sosialisasi anak.

4. Mengenalkan bermacam-macam lingkungan.

Pengalaman anak bergaul dengan berbagai macam lingkungan dapat memperkaya wawasan anak dalam bersosialisasi. Misalnya, sesekali ajak anak berbelanja ke pasar, kemudian minta anak untuk belajar bertanya dengan sopan pada penjual atau melakukan transaksi jual beli. Hal ini selain bisa memberi pengalaman bagi anak, juga bisa melatih kepercayaan din anak dalam bersosialisasi dengan iingkungan sekitar. Selain itu, anak juga bisa dibawa mengunjungi panti asuhan agar anak dapat saling berbagi, berempati, serta memiliki kepekaan sosial. Berilah kebebasan kepada anak untuk bergaul dengan bermacam-macam lingkungan. Narnun, sebagai 
orang tua kita perlu memberi bekal pemahaman kepada anak mengenai lingkungan yang baik dan kurang baik baginya. Hal ini dapat dilakukan misalnya dengan cara mengajak anak untuk berdialog dan menceritakan siapa teman-temannya, bagaimana sifat-sifat dan tingkah lakunya.

B. Membangun Sosialisasi Pada Anak

Membangun dan memilihkan lingkungan sosial yang sehat adalah tugas berat bagi orang tua masa kini. Karakter dan bahasa negatif tersebar terlalu merata. Televisi, keluarga besar, tetangga, kompleks perumahan, dan sekolah tidak menjamin bebas dan bahasa negatif (Fariyatul \& Bandono, 2017). Terkadang di sekolah tidak semua bisa dijadikan contoh karena pengaruh teman-teman sebaya lebih mendominasi dibandingkan lingkungan di rumah. Sebaliknya, ada pula di lingkungan rumah yang justru menjadi mimpi buruk para orang tua untuk ekstra ketat mengawasi pengaruh buruk anak-anaknya. 


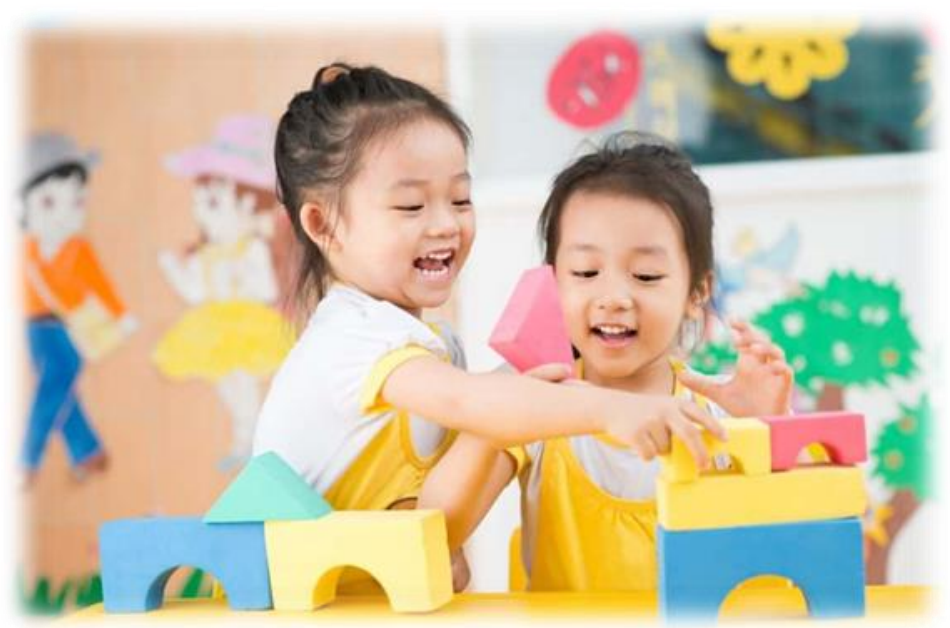

Gambar 4. Membangun Sosialisasi Anak

Bagaimana dengan media massa? Film anak-anak pun saat ini berisikan perkelahian, perang. dan permusuhan. Kata-kata kasar dan sumpah serapah dari tokoh-tokoh jahatnya. Padahal, masa emas atau golden age ditambah dengan masa prabalig bagi orang muslim adalah masa penting pendidikan. Jika kita tidak mengimbangi respons terhadap faktor ini dengan terus belajar, tentu kita tidak bisa menciptakan sambungan-sambungan neuron di otak yang positif, bahkan pengaruhnya sangat vital bagi perkembangan anak (Maisari \& Purnama, 2019). Setidaknya kita tidak ingin anak dibiarkan tumbuh tanpa memilihkan lingkungan yang positif dan menjauhkan mereka dan lingkungan yang negatif. Kita sudah berusaha mengenalkan kepada mereka keseimbangan antara kreatif dan nilai-nilai etika, tetapi tetap 
saja para orang tua dituntut untuk double jobs (tugas ganda), yaitu memberi anak-anak makanan bergizi atau berdoa serta berharap agar anak-anak berakhlak baik, sopan, dan memberi teladan. Jadi, bagaimana seharusnya anak bersosialisasi? Ya, akrabilah sekolah anak kita. Sejak masuk sekolah, anak-anak kita menghabiskan sebagian besar harinya di bawah asuhan guru-guru dan pegawai sekolah.

C. Sekolah, Sarana Aktualisasi dan Menggali Potensi Anak

Setiap anak memiliki kelebihan dan talenta yang sebagian sudah bisa tampak sejak usia dini. Ada sebagian keluarga yang secara cermat melihat potensi yang dimiliki anaknya dengan memasukkan ke sekolah tambahan atau les. Ada pula yang melihat anak selalu bergairah ingin beraktualisasi dalam ragam kegiatan, tetapi di rumah tidak mempunyai akses untuk menggalinya hingga menjadi potensi berbakat. Namun, tidak jarang pula masih ada kemampuan dan bakat lain yang baru muncul di usia-usia tertentu dan karena faktor dorongan keluarga anak menjadi sukses di sekolah. Semua potensi ini adalah sangat alami meskipun bisa ditularkan. Artinya, melalui sekolah, kemampuan terpendam anak kita dapat terdeteksi meskipun tidak seutuhnya. Potensi yang dimiliki anak jelas sudah bisa kita lihat sejak ia belum mengenal sekolah. Lagi-lagi orang tualah yang lebih cepat tahu bagaimana sang anak bisa melakukan banyak hal, seperti menggambar, membuat kriya, kreasi, serta membuat puisi dan bersenandung merdu. Ketika di rumah sudah mendapat cikal bakal yang menonjol pada sang anak, setidaknya aktualisasikan potensi sang anak pada even- 
even sekolah, baik yang rutin maupun kompetisi antarsekolah.

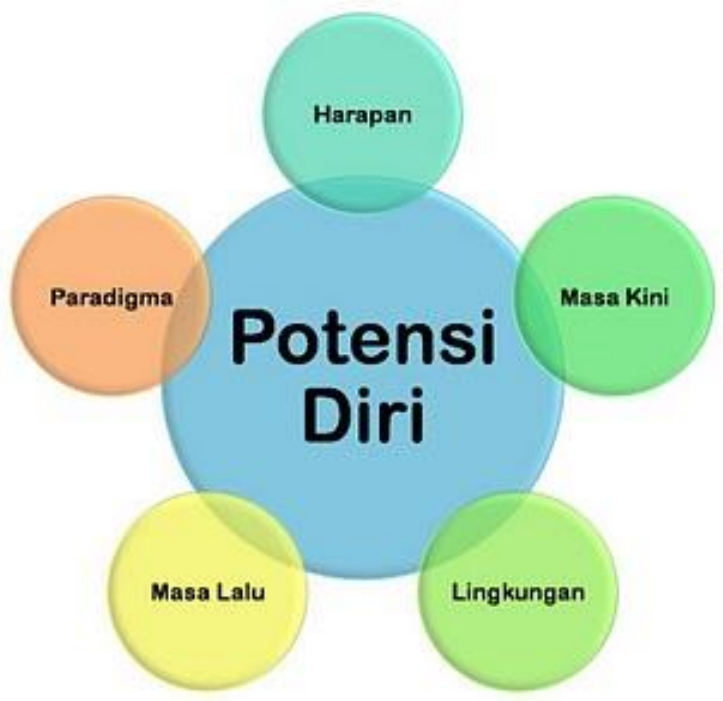

Gambar 5. Menggali Potensi Siswa

\begin{abstract}
Di beberapa sekolah, justru membuka selebar-lebarnya ekstrakurikuler yang menampung banyak potensi anak, mulai dari yang bersifat akademis, seperti mahir menggunakan sempoa, laboratorium sains, sanggar seni dan sastra, hingga cabang-cabang olahraga. Ragam sarana aktualisasi ini dapat dijadikan alternatif anak untuk memacu keterampilan mereka dalam mengembangkan bakat dan minat.
\end{abstract}




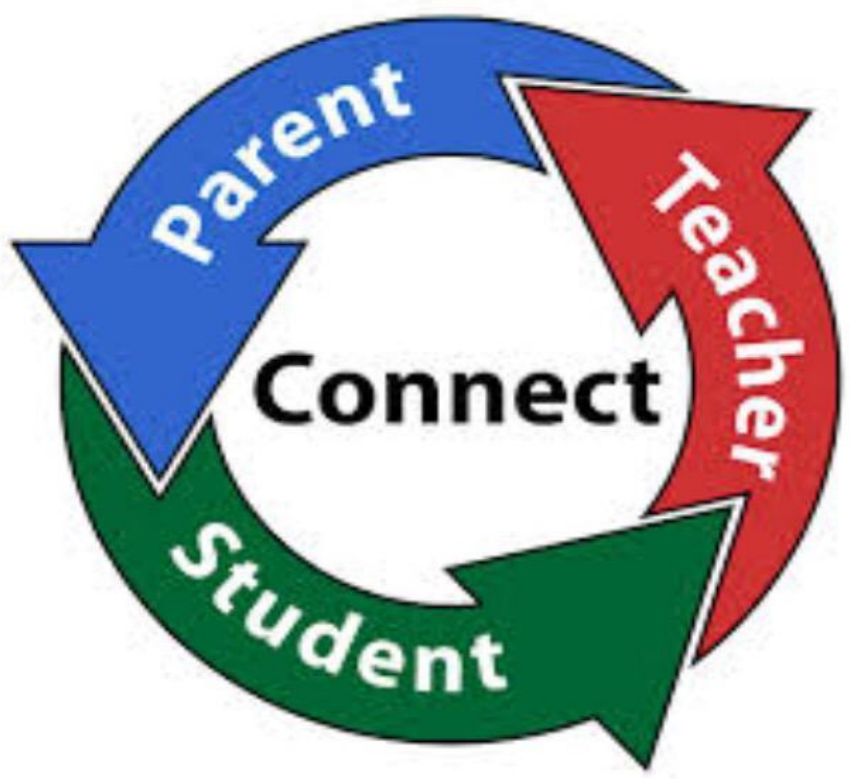

Gambar 6. Kolaborasi Pilar Pendidikan

Peran keluarga, sekolah dan masyarakat menjadi sangat penting dalam mengimplementasikan layanan pendidikan berbasis ramah anak, karena pada dasarnya pendidikan yang utama dan ideal harus melibatkan ketiga unsur tersebut sebagai penjamin sekaligus pengendali sesuai dengan fungsinya masing - masing. Kehadiran institusi pemerintah

Tabel 1. Komponen Sekolah Ramah Anak

\begin{tabular}{lll}
\hline No & Ruang Lingkup & \multicolumn{2}{c}{ Uraian } \\
\hline 1 & Keluarga & $\begin{array}{l}\text { 1. } \\
\text { Pusat pendidikan pertama dan } \\
\text { utama }\end{array}$ \\
\hline
\end{tabular}




\begin{tabular}{ll}
\hline & $\begin{array}{l}\text { 2. } \\
\text { Fungsi proteksi sekaligus } \\
\text { memberi ruang berekpresi dan } \\
\text { berkreasi dan berprestasi }\end{array}$ \\
\hline $2 \quad$ Sekolah & 1. $\begin{array}{l}\text { Melayani seluruh kebutuhan } \\
\text { peserta didik. } \\
\text { 2. }\end{array}$ \\
& $\begin{array}{l}\text { Memberikan kepedulian yang } \\
\text { tinggi dan menyeluruh pada } \\
\text { peserta didik sebelum dan } \\
\text { sesudah pembelajaran }\end{array}$ \\
3. $\begin{array}{l}\text { Menghormati hak-hak anak dan } \\
\text { kesetaraan gender. }\end{array}$ \\
4. Sebagai sahabat peserta didik \\
dalam semua situasi
\end{tabular}

Pada usia remaja atau periode perkembangan lebih Lanjut, remaja mulai mengungkapkan rasa ingin tahu yang tinggi. Hal-hal apa dan dengan siapa remaja bergaul aktivitas kesorang tuakannya sehari-hari bisa menjadi awal untuk menelusuri dan mengembangkan berbagai minat yang mungkin pada usia muda belum tampak atau belum menjadi fokus perhatiannya. Rasa ingin tahu remaja kerap kali diikuti dengan kebutuhan untuk mencoba atau melakukannya. Oleh karena itu, adanya bimbingan orang tua yang terarah, masa remaja bisa menjadi masa yang menguntungkan untuk anak mengembangkan bakat dan kemampuan tertentu. Berikut ini beberapa hal yang perlu diperhatikan oleh orang tua, guru, 
dan lingkungan dekat anak dalam upaya menggali potensi dan minat anak.

1. Pengamatan sang orang tua sejak usia dini biasanya lebih daripada sang ayah. Perhatikanlah dengan penuh kasih sayang berbagai kelebihan, keterampilan, dan kernampuan yang tampak menonjol pada din anak. Sharing-lah bersarna suami jika memang ada yang tampak membahayakan atau aneh bagi anak, misalnya terpengaruh narkoba atau mengikuti balap liar.

2. Bantulah anak meyakini dan fokus pada kelebihan dirinya. Dialog terlebih dahulu lebih penting daripada langsung mewujudkan keinginannya. Jika perlu, diskusikan dengan guru di sekolah.

3. Stimulasikan anak untuk meluaskan kemampuannya dan satu bakat ke bakat yang lain.

4. Tumbuhkan antusias terhadap diri sendiri dengan mengembangkan konsep diri yang positif.

5. Tingkatkan motivasi anak untuk mengembangkan dan melatih kemampuannya dengan berlatih bersama orang orang pintar sebelumnya.

6. Perkaya anak dengan berbagai wawasan, pengetahuan, dan pengalaman di berbagai bidang.

7. Sediakan dan fasilitasi sarana bagi pengembangan bakat jika sekolah belum mampu menampung potensi yang lebih unik. Misalnya, untuk kompetisi balapan mobil di sirkuit.

8. Usahakan berbagai cara untuk meningkatkan minat anak untuk belajar dan menekuni bidang keunggulannya serta bidang-bidang lain yang berkaitan. 
9. Orang tua yang perhatian bukan dan banyaknya fasilitas yang diberikan, melainkan penghargaan dan pujian untuk setiap usaha yang dilakukan anak sekecil apa pun itu.

10. Dukunglah anak untuk mengatasi berbagai kesulitan dan hambatan dalam mengembangkan bakatnya. Jadilah teman curhat yang setia dan rela untuk menjadi soulmate-nya.

11. Pupuklah dalam diri anak untuk selalu menjalin huhungan baik serta akrab antara orang tua, guru, dan rekan-rekan seusianya.

D. Memantau Kecerdasan Anak

Seperti yang dikemukakan oleh Stephen R. Covey dalam The 7 Habits of Highly Effective People, "Orang yang benarbenar efektif memiliki kerendahan dan ketulusan hati untuk mengakui keterbatasan perseptual-nya sendiri dan mengapresiasi sumber sumber daya yang kaya yang ada melalui interaksi dengan hati dan pikiran orang lain (Fahyuni, 2018). Orang menghargai perbedaan karena perbedaan itu rnemperkaya pengetahuannya dan menambah pemahamannya terhadap kenyataan ini. Ketika kita dibiarkan begitu saja pada pengalaman kita sendiri, kita tetap menderita kekurangan. Oleh karena itu, kebanyakan kita mempunyai jenis dan bentuk campuran kecerdasan dan tidak seharusnya melabeli begitu saja seorang anak. Kita bisa menguatkan rasa percaya dirinya agar tetap maju mengikuti peradaban. Kecerdasan majemuk atau dikenal dengan multiple intelegence merupakan ragam kecerdasan yang 
dimiliki oleh setiap manusia yang bersifat unik manusia satu dengan yang lainnya. Berikut ini merupakan ragam multiple intelegence.

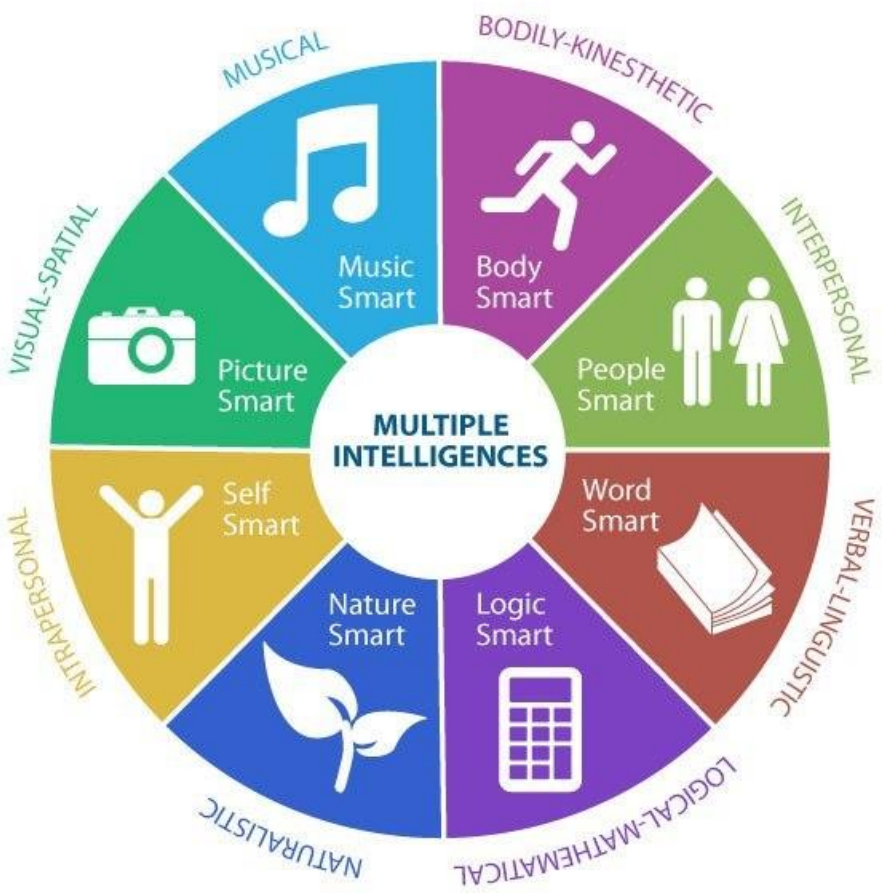

Gambar 7. Multiple intelegence

\section{Linguistik}

a. Anak gemar permainan kata.

b. Membuat permainan kata, plesetan kata, pantun jenaka, Anak suka sajak, cerita, dongeng, dan rima. 
c. Anak membaca segala jenis bacaan: buku, majalah, koran, bahkan label produk.

d. Anak mudah dan percaya diri dalam berekspresi, baik lisan maupun tulisan, rnaksudnya, anak adalah pendebat yang persuasif (meyakinkan) dan pengisah atau penulis yang baik.

e. Anak sering membumbui percakapan anak dengan pepatah, peribahasa pada hal-hal yang telah dibaca atau didengar.

f. Di sekolah, anak lebih suka pada subjek-subjek, seperti bahasa Inggris, sejarah (bahasa dan literatur atau sastra), dan IPS. Anak sadar perlunya mengembangkan perbendaharaan kata anak Anda.

\section{Logis-Matematis}

a. Anak suka bergelut dengan bilangan dan mampu mengerjakan hitungan dalam hati.

b. Anak berminat pada temuan ilmiah dan gemar bereksperimen dengan benda-benda dan hal-hal untuk memahami kerja mereka.

c. Anak mudah mengatur uang jajannya.

d. Anak membuat catatan kecil dalam aktivitasnya sehari-hari.

e. Anak suka menyusun suatu rencana perjalanan lorang tuaran atau perjalanan sekolah yang terinci. Anak sering mempersiapkan, membilang, dan mengimplementasikan sebuah daftar atau agenda "apa yang hendak dilakukan". 
f. Anak senang tantangan yang memeras otak atau perhitungan lainnya dan permainan yang menuntut pemikiran statistik dan logika, misalnya catur dan bridge.

g. Anak cenderung mudah mengidentifikasi kekeliruan logika pada hal-hal yang dikatakan atau dilakukan orang lain.

h. Matematika dan sains adalah subjek kegemaran anak di sekolah.

\section{Visual}

a. Anak sangat terampil memilah sesuatu menjadi beberapa bagian dan kemudian memasangkan kembali.

b. Anak dapat merakit benda dengan mudah dan dapat menyusun diagram dengan mudah pula.

c. Di sekolah, anak menggemari pelajaran seni dan lebih suka geometri daripada aljabar.

d. Anak kerap membuat apa yang menjadi titik perhatian anak dengan menyusun diagram atan menggambar dan dapat dengan mudah menafsirkan karya-karya.

e. Anak memiliki apresiasi terhadap seni visual dan suka lukisan dan ukiran.

f. Anak menyukai corat-coret ketika membuat catatan.

\section{Kinestetik-Tubuh}

a. Anak turut ambil bagian dalam suatu jenis olahraga atau secara teratur menjalankan beberapa jenis 
pengalaman fisik. Anak suka berjalan, berenang, dan sensasi menggunakan tubuh.

b. Anak sangat terampil dalam mengerjakan tugastugasnya sendiri.

c. Anak suka memahami masalah sambil melakukan atau terlibat dalam kegiatan tisik, seperti melompat atau berlari.

d. Anak kurang menyukai berpakaian rapi di berbagai arena.

e. Anak menyukai petualangan yang bersifat tantangan.

f. Anak menyenangi permainan fisik, meraba, atau merekayasa. Pelajaran yang paling menyenangkan di sekolah adalah olahraga.

\section{Musikalitas}

a. Anak dapat memainkan alat musik.

b. Anak dapat menyanyikan lagu pada berbagai kunci nada.

c. Biasanya anak dapat mengingat sebuah lagu setelah mendengar dua atau tiga kali saja.

d. Anak suka dan sering mendengarkan musik di rumah atau di jalan (dengan walkman, misalnya), dan kadang-kadang pergi ke konser. Anak suka dan menbutuhkan latar belakang musik ketika belajar.

e. Anak suka mengetuk-ngetukkan jan saat mendengar musik dan mempunyai selera irama yang baik.

f. Anak dapat mengidentifikasi suara alat-alat musik yang berbeda. 
g. Musik tema atau jinggel komersial sering tiba-tiba menyeruak ke benak anak.

\section{Interpersonal}

a. Anak suka bekerja dengan orang lain sebagai bagian dari suatu kelompok atau panitia.

b. Anak bangga menjadi pembimbing atau penasihat bagi orang lain.

c. Orang cenderung datang kepada anak untuk meminta saran. Anak dapat menampilkan diri sebagai orang yang simpatik.

d. Anak lebih menyukai olahraga tim, seperti bola basket, softbol, dan sepakbola daripada olahraga individual, seperti renang dan tari.

e. Anak menyukai permainan yang melibatkan orang lain, misalnya bridge, monopoli, dan ular tangga.

f. Anak adalah "kupu-kupu" sosial. Anak lebih suka kumpul-kumpul ketimbang sendirian di rumah menonton televisi.

g. Anak dapat berkomunikasi secara nyaman dengan orang lain dan dapat membantu menyelesaikan perselisihan.

\section{Intrapersonal}

a. Anak sering menyisihkan "waktu tenang" untuk merenungkan hal-hal yang sangat menyentuh pribadi dan perasaan yang sudah dia alami. 
b. Anak menetapkan tujuan sendiri dan sudah mengetahui kemana akan menuju.

c. Anak pemikir bebas, ia mengetahui dan membangun pikiran sendiri.

d. Anak mempunyai kegemaran pribadi yang tidak dapat dilakukan bersama dengan orang lain.

e. Anak menyukai melakukan kegiatan sendirian, misalnya menggambar dan melukis. Ide tentang lorang tuaran panjang lebih rnenyukai ke puncak bukit daripada mal dan kawasan banyak orang.

\section{Naturalis}

a. Anak mempunyai pemahaman dan minat terhadap hal-hal unik yang ia lihat.

b. Anak memiliki informasi yang memudahkannya untuk mengetahui lebih hanyak informasi astronomi, asal mula jagat raya, dan evolusi kehidupan.

c. Anak berminat pada masalah sosial, psikologi, dan motivasi manusia.

d. Anak berpandangan bahwa pelestarian sumber daya dan mencapai pertumbuhan yang berkelanjutan adalah dua ide cemerlangnya.

Sebagai guru dan orangtua dapat memeriksa setiap pernyataan yang berlaku pada diri anak dan perhatikan! Manakah dari 8 kriteria kecerdasan tersebut yang lebih menonjol? Bandingkan total-total dan kedelapan kecerdasan tersebut, kita pun akan melihat dengan mudah kekuatan dan 
kelemahan anak. Makin tinggi pilihan anak, makin cocok anak dengan kecerdasan tersebut.

Dengan menjawab pertanyaan-pertanyaan yang sudah dijawab anak, kita mampu mcmperkirakan bentuk kecerdasan anak yang paling kuat dan paling lemah. Kuis ini pun memungkinkan para orang tua dan orang tua memusatkan perhatian pada upaya untuk meyakinkan bahwa dirinya telah menggunakan sebagian besar kemampuan yang dia miliki dan kita bisa tahu apakah kita dapat membantu anak mengembangkan sebagian kemampuan lainnya. 


\section{KESIMPULAN}

Membangun dan memilihkan lingkungan belajar sosial yang sehat adalah tugas berat bagi orang tua masa kini. Karakter dan bahasa negatif tersebar terlalu merata. Televisi, keluarga besar, tetangga, kompleks perumahan, dan sekolah tidak menjamin bebas dan bahasa negatif. Terkadang di sekolah tidak semua bisa dijadikan contoh karena pengaruh teman-teman sebaya lebih mendominasi dibandingkan lingkungan di rumah. Sebaliknya, ada pula di lingkungan rumah yang justru menjadi mimpi buruk para orang tua untuk ekstra ketat mengawasi pengaruh buruk anakanaknya. 


\section{SOAL-SOAL}

1. Apa yang dimaksud dengan bersosialisasi pada anak di sekolah?

2. Mengapa bersosialisasi dibutuhkan oleh setiap peserta didik?

3. Jelaskan seperti apa praktiknya peserta didik beersosialisasi dengan lingkungannya?

4. Bagaimana cara menggali potensi peserta didik di sekolah?

5. Apa pentingnya guru mengenal dan memahami kecerdasan majemuk setiap peserta didiknya? 


\section{DAFTAR PUSTAKA}

Agbarachi Opara, J., \& Silas Oguzor, N. (2011). Inquiry Instructional Method and the School Science Currículum. Current Research Journal of Social Sciences, 3(3), 188-198.

Aritonang, S. D., Hastuti, D., \& Puspitawati, H. (2020). Pengasuhan Ibu, Keterlibatan Ayah Dalam Pengasuhan, dan Perkembangan Kognitif Anak Usia 2-3 Tahun di Wilayah Prevalensi Stunting. Jurnal IImu Keluarga \& Konsumen, 13(1), 38-48.

Çobanoğlu, F., Ayvaz-Tuncel, Z., \& Ordu, A. (2018). Childfriendly schools: An assessment of secondary schools. Universal Journal of Educational Research, 6(3), 466477. https://doi.org/10.13189/ujer.2018.060313

Fariyatul, E., \& Bandono, A. (2017). The use of value clarification technique-based- picture story media as an alternative media to value education in primary school. Harmonia: Journal of Arts Research and Education, 17(1),

68.

https://doi.org/10.15294/harmonia.v17i1.7469

Pennings, H. J. M., Brekelmans, M., Sadler, P., Claessens, L. C. A., van der Want, A. C., \& van Tartwijk, J. (2018). Interpersonal adaptation in teacher-student interaction. Learning and Instruction, 55, 41-57. https://doi.org/10.1016/j.learninstruc.2017.09.005

RI, K. A. (2012). Al Qur'an Terjemah (T. S. Qur'an, ed.). Bandung: Syaamil Qur'an.

Saat, S. (2010). Pendidikan Anak Dalam Al Qur'an. Lentera Pendidikan, 13(1), 64-77.

Setyastuti, Y., Suminar, J. R., Hadisiwi, P., \& Zubair, F. (2019). Millennial moms: Social media as the preferred source of information about parenting in Indonesia. Library 
Philosophy and Practice, 2019.

\section{Bab III Sekolah dan Peluang Masa Depan}

\section{A. Sekolah Masa Depan}

Tampaknya, sekolah tetap menjadi prioritas harapan meraih masa depan. Semua keinginan orang tua dan dukungan sang ayah mengharapkan anaknya menjadi anak yang berrnanfaat dan sukses di masa depannya. Bagairnana dengan para orang tua yang tidak sanggup rnenyekolahkan anak-anaknya karena keterbatasan nafhah dari suami? Harapan mereka pun tentu pupus karena mereka lebih mengutamakan kelangsungan hidup daripada sekolah.

Kerap kali kita terjebak oleh pola pikir bahwa sekolah hanya mengutamakan nilai akademis dan prioritas kecerdasan tertulis, padahal sekolah membimbing dan mendidik kita agar bisa meraih masa depan yang lebih baik. Tentu yang menjadi harapan adalah masa depan agar anakanak kita menjadi mandiri, sukses, dan bermanfaat bagi orang-orang yang ada di sekitarnya. Apakah menjadi anak yang sukses selalu dengan bersekolah formal? Ataukah menjadi pianis terkenal harus dengan bersekolah di luar negeri? Pada dasarnya sekolah formal atau sekolah nonformal sekalipun adalah sama dengan pendidikan dasar di rumah. Orang tua dan ayah adalah tokoh utama dalam pendidikan ini. Prinsip-prinsip dasar dan teknikal yang dimiliki oleh orang tua inilah yang menjadi langkah awal anak untuk menatap masa depannya. Tentu saja dengan bimbingan pihak luar, siapa saja, yaitu sekolah-sekolah yang berada di 
luar lingkungan rumah, sekolah umum atau agama, dan sekolah formal atau nonformal.

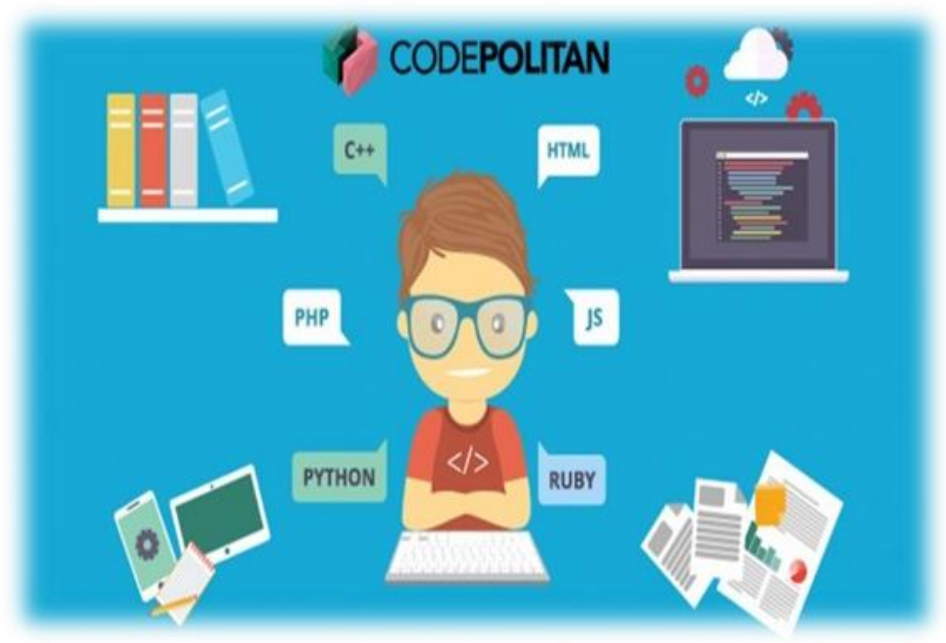

Gambar 8. Sekolah Masa Depan

Sekolah di rumah tentu tidak sama dengan sekolah di luar rumah. Ada yang mengatakan bahwa sekolah di rumah atau dididik langsung oleh orang tua bukanlah sekolah. Keterbatasan informasi dan pengetahuan dunia luar justru menjadi hambatan, padahal anak pada masanya harus banyak tahu mengenai banyak hal(Mouri, Kousuke; Uosaki, Noriko; Ogata, 2018). Dan, hal ini bisa didapatkan dan banyak tempat. Kenyataan lainnya adalah pola pikir orang tua dan orang tua yang masih melihat nilai akademis adalah jawaban dan masa depan anak yang lebih baik. Padahal, nilai akademis belum menentukan anak itu sukses di masyarakat. Oleh karena itu, bukanlah jaminan jika tidak sekolah formal 
atau di ruang kelas, anak tidak rnendapatkan masa depannya, tetapi mereka bisa mendapatkannya dengan pelajaran yang didapatkan dari pengalaman orang tua dan tambahan ilmu dan lingkungan sekitarnya. Lantas, seperti apakah sekolah yang memang memberi peluang meraih masa depan?

1. Sekolah yang memberi kesempatan anak didiknya untuk menghargai setiap bakat dan potensi yang ada dalam dirinya, apa pun potensi itu. Banyak sekolah yang hanya mengutamakan nilai akademis dan tidak melihat factor "kelebihan" lain yang bisa menunjangnya untuk maju menjadi lebih baik. Akan tetapi, jawabannya tetap saja bahwa sekolah formal adalah sekolah yang menomorsatukan pendidikan akademis. Toh, ada sekolah kejuruan atau pilihan menurut bakat di sekolah khusus. Padahal, yang dimaksud para orang tua bukan demikian, kan? Kita menginginkan potensi lain yang ada alam diri anak kita dilihat sebagai potensi yang bisa menunjang anak mau menjadi siswa yang cerdas seutuhnya.

2. Sekolah yang menyeimbangkan nilai-nilai belajar mengajar secara akademis dengan nilai-nilai sikap, perilaku, kemandirian, keterampilan, dan keahlian lain yang mendukung. Artinya, sekolah tidak mencetak alumni yang cerdas $\mathrm{IQ}$, melainkan juga alumni yang $\mathrm{EQ}$ dan SQ-nya di atas rata-rata.

3. Sekolah yang keberhasilan alumninya dapat diterima di sekolah lanjutan yang kualitasnya baik serta memiliki life 
skill yang cukup mampu untuk eksis di tengah masyarakat.

4. Sekolah yang memiliki prestasi dan profil output-nya yang bisa memberi teladan dalam proses dan hasil akhir belajar mengajar di setiap tahun ajarannya. Adapun yang disebut prestasi tidak hanya secara akademik, melainkan juga non akademik, baik siswa, guru, maupun institusinya.

5. Sekolah yang memberi peluang dan kesempatan untuk belajar lebih aman dan nyaman tanpa tekanan biaya sekolah dan indikasi anak akan putus sekolah.

6. Pada sekolah kejuruan, sekolah memberi nilai lebih pada kualitas aplikasi di lapangan. Dengan kata lain, siswa bisa langsung terjun ke masyarakat dan mengembangkan jiwa enterpreneur sejati.

7. Pada sekolah minat atau bakat, siswa tidak sekadar mahir dan menguasai keahliannya secara mumpuni, melainkan juga bisa mengembangkan kreativitasnya bersama komunitas yang ada di luar sekolah. Di dalam komunitas luar sekolah ini, siswa mampu berprestasi pada even-even bergengsi dan meningkatkan kepercayaan dirinya.

8. Sekolah yang memberi banyak gambaran tentang kemampuan untuk mengenal banyak profesi dan keterampilan sebagai jalan meraih kesuksesan, seperti profesi menjadi pendidik, teknisi, trainer, atlet, atau praktisi multytalent. 
B. Perlukah Observasi Sekolah?

Sebagai orang tua tentunya kita semua berharap sekolah yang dipilih mampu menjadi tempat mengembangkan kemampuan anak secara optimal. Apa saja yang bisa orang tua observasi di lapangan sebagai bahan berdiskusi menyekolahkan anak?

1. Lokasi sekolah dan lingkungan.

Lokasi yang dimaksud dapat dipandang dari jarak sekolah ke rumah, lingkungan sekitar, dan sarana transportasinya. Bisa dibayangkan jika seorang anak harus bangun pagi-pagi sekali dikarenakan letak sekolahnya yang jauh. Akibatnya, ia akan pulang dalam keadaan lelah karena jarak yang ditempuhnya memakan waktu yang lama. Belum lagi jika terjadi kemacetan lalu lintas, bisa dimungkinkan sering terlambat pulang dan masuk sekolahnya.

2. Sarana fisik.

Selain nama sekolah, kondisi fisik dan sarana fisik sekolah adalah hal yang cukup penting orang tua cermati. Mulai dari bangunan fisik, ruang kelas, taman, perpustakaan, laboratorium, sarana olahraga dan kesenian, arena bermain, kantin, perlengkapan kelas, sampai dengan alat peraga edukasi yang dimiliki. Seiring dengan kemajuan bidang informasi dan teknologi, tampaknya bukan hal baru sebuah sekolah memiliki fasilitas akses 
jaringan internet dan website sendiri sehingga setiap stake holders dapat berinteraksi dan berkomunikasi di dunia maya. Hal ini akan sangat membantu bagi orang tua untuk memantau perkembangan putra-putrinya secara cepat tanpa harus secara fisik datang ke sekolah. Dengan didukung sarana dan prasarana yang baik diharapkan semua peserta didik dapat belajar secara nyaman dan betah. Sekolah diibaratkan sehagai rumah kedua bagi anak-anak sehingga sekolah yang baik mampu memenuhi kebutuhan dan keinginan siswa. Hal yang perlu diperhatikan juga mengenai rasio jumlah siswa dengan luas ruangan kelas serta fasilitas pembelajaran yang lain.

3. Visi dan misi sekolah.

Banyak ahli menyatakan pentingnya aspek visi dan misi pendidikan yang disandang suatu sekolah. Sekolah yang memiliki kualitas baik tentu saja memiliki visi dan misi yang jelas, terukur, dan realistis. Akan tetapi, benarkah hal ini penting bagi orang tua? Bagaimana mengetahuinya? Sempatkah kita untuk mencari tahu visi dan misinya atau malah hal ini akan mengganggu konsentrasi kita untuk menyekolahkan dia seperti layaknya anak-anak yang tanpa dipusingkan dengan hal-hal formalitas?. Setiap sekolah, baik sekolah negeri maupun swasta memiliki visi dan misi. Ada sekolah yang memasang visi dan misi sekolah ini tepat di gardu pintu masuk, ada pula yang ditulis di dalam brosur-brosur, ada 
pula yang menempel di setiap ruang kelas sekolah, bahkan untuk sekolah-sekolah yang berkapasitas besar dan memiliki dana yang cukup besar untuk mengadakan road show, promosi, maupun event sponsorship, mereka tidak pernah ketinggalan mencantumkan visi dan misi. Bahkan, sebelum presentasi mengenal keunggulan sckolah, visi dan misi ini menjadi hal pertama yang diinformasikan pihak sekolah atau yayasan sekolah.

Dengan demikian, orang tua seharusnya tidak lagi terjebak pada istilah-istilah sekolah favorit, unggulan, plus, dan lain-lain. Padahal, yang dikembangkan hanya aspek kognitif atau academic minded. Sekolah yang baik adalah sekolah yang mampu menggali, mengembangkan, dan mengoptimalkan seluruh potensi (baca: kecerdasan majemuk) peserta didiknya.

4. Porsi pendidikan agama.

Pantas saja jika orang tua mengharapkan pelajaran adalah pelajaran yang harus mendapat perhatian orang tua. Meskipun pelajaran agama di sekolah umum sangat terbatas. Artinya, kita tidak bisa menghindari kasus-kasus yang menimpa generasi penerus kita termasuk para pelajar, mulai dan kasus tawuran, narkotika, pergaulan bebas, dan perbuatan menyimpang lainnya. Jadi, peran pendidikan agama menjadi sangat signifikan terutama dalam membentuk karakter dan perilaku siswa. Melalui pendidikan agama yang cukup, 
diharapkan anak-anak kita akan muncul kesadaran dan pemaharnan yang benar mengenai tugas, penan, dan tanggung jawabnya sebagai hamba Allah, anak, siswa, dan anggota masyarakat. Sebagai implementasinya, anak mampu menghargai orang lain dengan segala perbedaan serta mampu memilah dan memilih kegiatan-kegiatan yang bermanfaat dan tidak.

Dengan demikian, porsi pendidikan agama yang diterapkan oleh suatu sekolah hendaknya menjadi bahan pertimbangan penting para orang tua dan orang tua serta anak dalam memilih sekolah, Barangkali jika kita ingin mendapatkan pendidikan agama yang lebih di sekolah negeri, tampaknya sulit diwujudkan. Pasalnya, sesuai dengan aturan yang berlaku, sekolah-sekolah negeri hanya menerapkan dua jam pelajaran agama dalam sepekan, kecuali inisiatif pihak sekolah untuk mengadakan jam tambahan.

5. Profil pendidik.

Guru atau pendidik di sekolah merupakan ujung tombak dalam pengajaran, dari mana mereka asal dan seberapa besar minat mereka pada pendidikan untuk mencetak dan mengader generasi penerus yang didambakan. Keberhasilan dari proses dan hasil oulput pendidikan tidak dapat dilepaskan oleh andil guru. Beberapa sekolah sangat ketat dengan latar belakang pendidikan guru dengan melihat asal jurusan yang relevan serta memiliki ijazah dan 
sertifikat mengajar secara resmi. Akan tetapi, ada sekolah yang menerirna guru dari berbagai bidang disiplin ilmu, asalkan bisa mengajar dan memiliki pengalaman dalam dunia training atau pengajaran. Biasanya sekolah-sekolah swasta relatif sangat kompromi meskipun ada beberapa sekolah swasta unggulan, mahal, dan favorit, memilih gurunya harus berlatarbelakang minimal S1 meskipun hanya untuk mengajar SD, bahkan TK sekalipun. Pendidik ini tentu sangat penting bagi orang tua untuk menjadi sahabat berbagi, terutama dalam perkembangan sosialisasi anak di sekolah. Perkembangan sosialisai tidak sekadar dalam pengenalan lingkungan, melainkan transfer ilmu dan pelajaran, berbagai informasi, dan ekspiorasi bakat dan kemampuan alamiah anak.

Apalah artinya kurikulum yang ideal jika tidak didukung oleh pelaksananya, yaitu sumber daya manusia yang cakap. Jadi, tidak heran jika pemerintah terus-menerus berusaha meningkatkan kompetensi guru melalui berbagai program, mulai dari penataran-penataran, beasiswa pendidikan, dan sertifikasi guru. Para orang tua dan orang tua bisa melihat elemen atau profil pendidik ini melalui program pengenalan siswa dan guru di sekolah. Biasanya satu per satu guru akan diperkenalkan kepada orang tua siswa, terutama para wali kelas.

6. Kurikulum pembelajaran. 
Kurikulum sekolah, kerap kali dilihat melalui buku paket pelajaran yang digunakan. Padahal, kewajiban sekolah memberikan kurikulum ini sesuai dengan masa proses belajar-mengajar yang berlangsung. Akan tetapi, orang tua memang tidak harus selalu dipusingkan dengan hal ini karena setiap mata pelajaran yang diberikan di sekolah biasanya sudah disesuaikan dengan kurikulum berbasis kompetensi. Adapun kelebihannya jika kita mengetahui kurikulum sekolah ini adalah kita bisa turut membimbing anak didik kita dalam hal memahami. mengerti, dan menerangkan hal-hal yang sebelumnya sudah ada di lembar kurikulum.

Kurikulum bisa dikatakan sebagai jantungnya pendidikan karena di dalamnya berisi perencanaan pembelajaran yang menyangkut semua kegiatan yang dilakukan dan dialami peserta didik dalam perkembangan, baik formal maupun informal guna mencapai tujuan pendidikan. Meskipun penerapan kurikulum ini sudah diatur dan diseragamkan dari pusat, pihak penyelenggara pendidikan dapat melakukan modifikasi-modifikasi disesuaikan dengan kondisi sekolah, lingkungan, dan kebutuhan masyarakat.

Dalam kebijakan kurikulum terbaru, yaitu Kurikulum Tingkat Satuan Pendidikan (KTSP) sangat memberikan keleluasaan pada pihak sekolah (negeri dan swasta) untuk berkreasi dan berinovasi selama masih mengacu pada standar kompetensi 
yang ditentukan. Kegiatan-kegiatan ekstrakurikuler yang diselenggarakan sekolah juga perlu dicermati, apakah dimungkinkan dapat mengoptimalkan bakat dan potensi peserta didik.

7. Alternatif aktivitas.

Kurikulum nasional menjadi acuan semua sekolah, baik negeri maupun swasta. Meskipun demikian, kerap kali aktivitas yang ditawarkan berbeda. Sekolah swasta menawarkan aktivitas yang khas dan tujuan yang khas pula. Dalam kesiapan mengikuti kegiatan formal, sekolah sekolah tertentu melakukan pemeriksaan dan evaluasi psikologi berkaitan dengan kesiapan anak mengikuti pendidikan di sekolah dasar.

Kondisi sekolah yang nyaman, teduh, tenang, tertib, dan lingkungan yang bersih tentu saja akan mendukung suasana proses pembelajaran. Berbeda dengan suasana sekolah yang terkesan kumuh, gersang, gaduh, penempatan perabot sekolah yang semerawut, dan tidak ada kedisiplinan yang diterapkan. akibatnya proses belajar-mengajar akan banyak terganggu dan kurang optimal hasilnya. Kata kuncinya, siswa di sekolah harus merasa senang dan betah, seperti ketika berada di rumahnya sendiri (feels like second home).

8. Keterampilan skolastik.

Banyak sekolah yang mensyaratkan anak menguasai membaca, menulis, dan berhitung saat 
pertama masuk sekolah, tetapi ada juga sekolah yang hanya melihat batas minimal usia anak, ada juga sekolah lain yang lebih toleran.

9. Lihat prestasi dan keberhasilan alumninya.

Alumni bukan sekadar bagian dari sekolah, melainkan suatu aset yang berkesinambungan hingga anak kita menjadi sosok manusia yang dibanggakan dunia. Oleh karena itu, setelah mendapatkan berbagai informasi dan melakukan observasi, jangan lupa berdiskusi dengan pasangan dan anak kita. Sebelum mengambil keputusan final, tidak ada salahnya kita beristikharah, memohon kepada Allah supaya menunjukkan sekolah yang terbaik untuk anak kita. Sebagai seorang muslim, kita harus senantiasa melibatkan Allah dalam setiap keputusan yang kita ambil, termasuk dalam memilih sekolah untuk anak kita.

Dari paparan tersebut, orang tua bisa mempertimbangkan sekolah mana yang memang ideal sesuai dengan kemampuan orang tua. Terlebih-lebih dengan diterapkannya sistem penerimaan siswa baru (PSB) online yang masih mengedepankan nilai akademik (ujian nasional) di dalam proses seleksinya. Hal ini tentu saja membuat keresahan dan kepanikan tersendiri, terutama bagi mereka yang nilainya di bawah ratarata kelas. Nah, semua orang tua bisa menilai mana 
sekolah yang seharusnya dikatakan ideal. Orang tua bisa memilihnya dari sudut mana pun.

\section{Memilih Sekolah Ramah Anak}

Sulit memang memilih sekolah yang benar-benar berkualitas dan tidak menyalahi filosofis pendidikan anak usia dini. Meskipun di kota besar banyak sekali prasekolah yang menawarkan berbagai keunggulannya, kita harus hatihati dalam menentukan pilihan. Kita perlu mengumpulkan informasi sebanyak mungkin sebelum membuat keputusan. Sekolah yang berkualitas adalah sekolah yang profesional dalam memberikan stimulasi positif untuk mengoptimalkan pertumbuhan dan perkembangan anak.

Banyak sekolah yang menyatakan diri sebagai sekolah yang berkualitas dengan menjual gedung dan fasilitas pendidikan yang lengkap atau memiliki jargon sebagai sekolah berstandar internasional. Padahal. bisa jadi pembelajarannya tidak sebaik gedung atau jargon yang dieluelukan. Meskipun masih cukup lama, tidak ada salahnya kita mulai berencana memilih sekolah untuk anak kita. Sebagai orang tua tentu kita ingin pendidikan yang terbaik untuk anak-anak kita bukan? Terutama untuk anak usia dini karena mereka berada pada masa usia keemasan (0-8 tahun) yang sangat penting bagi pertumbuhan dan perkembangan mereka ke depan. Oleh karena itu, pemilihan sekolah sebagai lembaga yang memberikan layanan pendidikan anak usia dini menjadi hal yang harus diperhatikan mengingat masih 
banyak sekolah yang belum menerapkan pembelajaran yang sesuai dengan pertumbuhan dan perkembangan anak. Beberapa di antaranya masih menerapkan pembelajaran konvensional yang satu arah. Anak masih dijadikan objek pembelajaran, bukan subjek pembelajaran sehingga kreativitas anak seperti digembok. Belum lagi, peletakan bermain yang hanya sebagai selingan kegiatan belajar, bukan inti pembelajaran. Padahal, lewat bermainlah anak belajar. Belajarnya anak, ya bermain.

Pernahkah para orang tua mengenal proyek Spektrum yang dirintis oleh seorang tokoh pendidik terkenal, Howard Gardner? Proyek ini bertujuan untuk meneliti apakah anakanak usia prasekolah sudah mernperlihatkan profil-profil kecerdasan khas mereka atau belum. Anak-anak dimungkinkan untuk mengikuti kecenderungan alamiahnya pada suatu ragam bahan atas dasar pilihan mereka dan mengungkapkan melalui aktivitas-aktivitas bermain yang merupakan kombinasi-kombinasi kekuatan dan minat tertentu mereka. Dengan demikian, orang tua bisa memilih sekolah dengan berorientasi belajar dengan semua kecerdasan. Orang tua bisa mencatat dalam catatan perkembangan anak bahwa selama rentang waktu di sekolah hari itu, masing-masing anak harus menerapkan permainan keseimbangan unik gaya belajarnya. Setiap orang tua menginginkan yang terbaik bagi anaknya, tetapi sebagian besar tidak pernah dibimbing bagaimana menciptakan lingkungan esensial guna menggali seluruh kemampuan awal anak sejak dini (Aritonang et al., 2020). 
D. Mengumpulkan Informasi SRA

Orang tua berperan penting untuk mencari informasi dan mendatangi sekolah yang diharapkan. Istilahnya, first thing's first, kita harus menentukan tips sekolah seperti apa yang hendak kita dan suami pilih untuk buah hati yang baru belajar mengenal sekolah. Ingatlah, yang akan menghabiskan waktu di sana adalah anak, bukan kita. Jadi, sesuaikan dengan minat anak dan program yang ditawarkan sekolah tersebut. Memang bukan suatu pilihan yang mudah karena sekarang ini kita 'dikepung' oleh sekian banyak tipe sekolah. Program yang ditawarkan sekolah untuk anak-anak usia dini cenderung dibagi dua kelompok: berbasis pada permainan dan program akademis. Orang tua sebaiknya, sebelum memutuskan piiihan, terlebih dahulu mencari dan mengumpulkan informasi ke berbagai sumber (baik dari saudara, teman sekantor, tetangga. maupun iklan di media massa) yang bisa merekomendasikan sekolah-sekolah tertentu.

\section{Catat sekolah yang menjadi prioritas sekolah anak.}

Prioritaskan apa yang menjadi tujuan anak disekolahkan. Gengsi kita. Kepintaran anak. Kualitas motorik anak. Kecerdasan jiwa sosialisasi anak. Semua bisa menjadi satu, tetapi kita coba untuk realistis bahwa anak kita masih balita. Jadi, milikilah daftar jenis preschool yang rasanya paling tepat untuk anak Anda, mulailah mendatangi lokasi sekolah-sekolah tersebut.

Ada beberapa faktor yang patut anda pertimbangkan ketika melakukan survei ke calon sekolah anak, misalnya lokasinya dekat ke rumah atau dekat ke tempat kerja 
Anda. Jika Anda bekerja dari pagi hingga petang, pertimbangkan pula jarak sekolah tersebut ke rumah orang tua atau saudara sehingga jika terjadi hal-hal yang mengkhawatirkan, mereka bisa secara cepat menggantikan kita mendatangi sekolah anak. Tanyalah kepada orang di sekitar kita, seperti teman, tetangga. kerabat, dan bagaimana pengalaman mereka menyekolahkan anak. Pendapat mereka bisa kita pertimbangkan, tetapi jangan lupa pula bahwa setiap anak diciptakan berbeda.

\section{Observasi semua yang patut diketahui.}

Luangkan waktu kita untuk mengadakan pertemuan dengan pihak sekolah agar memperoleh informasi selengkap-lengkapnya. Ada beberapa sekolah yang menyelenggarakan open house agar para calon murid dan orang tua bisa mengenal lebih dekat tentang sekolah yang bersangkutan. Di situ kita akan melihat karya-karya kreatif para murid, prestasi sekolah, aktivitas yang terdapat di sana, serta metode pengajaran seperti apa yang mereka berikan. Jika memang perlu, datangilah sekolah tertentu pada hari kerja, perhatikan sekeliling kita. Lihat cara murid-murid berinteraksi dengan guru dan sesama mereka. Apakah mereka terlihat akrab atau terasa berjarak? Tanyakan status atau akreditasi sekolah dan perizinannya (banyak orang tua yang lupa menanyakan ini, padahal meskipun prasekolah, hal ini sangat penting karena izin dan Diknas menjadi salah satu indikator kualitas sebuah lembaga pendidikan). 


\section{Pastikan pilihan yang tepat.}

Rangkum dan analisislah hasil obsenvasi kita dalam bentuk informasi yang selengkap-lengkapnya. Jadi, pilih yang mana? Jika kita masih ragu di antara 2 atau 3 pilihan, mulailah membuat satu daftar lagi berisi pertimbangan plus minus masing-masing sekolah. Dan penilaian itu, kita akan mendapatkan yang terbaik dari yang baik.

\section{Berdiskusi dengan keluarga.}

Suami istri harus saling rnenyetujui dan sama-sama sepakat untuk membahagiakan anak. Hal terpenting yang harus diingat oleh orang tua adalah sekolah hanyalah salah satu mitra dalam upaya pendidikan dan pengajaran anak. Jangan berharap bahwa anak akan berkembang jika orang tua tidak ikut berperan dan bertanggung jawab dalam proses pendidikannya. Walau bagaimanapun pendidikan yang paling bermakna dan membekas bagi anak adalah yang didapatkan di rumah, dan orang tua dan anggota keluarganya. Oleh karena itu, lakukan dari rumah apa saja yang bisa diselesaikan, seperti hal-hal teknis, siapa yang mengantar jemput, bekal makan anak, atau berapa lama di sekolah. Begitu pula, pada saat berada di sekolah (Setyastuti, Suminar, Hadisiwi, \& Zubair, 2019). Diskusikan dan kompromikan dengan semua anggota keluarga: orang tua, suami, pengasuh, nenek, atau dengan tetangga dekat yang bisa mengawasi ketika orang tua bekerja. Hal paling mendasar yang harus dilakukan oleh orang tua dalam 
upaya mencari sekolah untuk putra-putri di masa prasekolah. antara lain sebagai benikut.

a. Perhatikan dengan cermat dan teliti, bagaimana kondisi kesehatan anak. Anak yang sering sakitsakitan, mudah alergi, dan sensitif terhadap gejala penyakit seharusnya menjadi pertimbangan orang tua. Jangan di paksakan jika memang kondisi anak tidak memungkinkan ia harus cepat-cepat sekolah. Kondisi fisik yang rawan bisa memberi dampak buruk. baik pada diri anak maupun diri kita. Mungkin orang tua akan kerepotan jika tiba-tiba anak kejang-kejang, muntah-muntah, bahkan rewel yang membuat kita menjadi malah stres dan tidak nyaman mengasuh anak.

b. Perhatikan pula suasana hati orang tua, sedang bahagia, gundah, atan tidak tenang meninggalkan rumah. bahkan merasa terusik dengan tangis anak yang lain. Hal ini bisa membuat orang tua inenjadi bulan-bulanan tekanan batin. Sebaiknya hindarkan faktor-faktor psikis orang tua jika memang anak usia hayi sudah ingin orang tua ajak menjadi anak yang cepat besar. Dalam hal ini, binalah hubungan yang komunikatif dengan suami. Suami yang hangat dan berkenan mengantar atau perhatian terhadap perkembangan anak di sekolah bisa menguatkan hati kita untuk tetap menyamankan pula hati anak.

c. Mengecek lokasi sekolah yang dekat dengan rumah. Apabila tidak mencari sekolah yang unggul, tetapi jauh dan sekolah, pertimbangkan sarana 
transportasinya. Jika menggunakan mobil, anak akan bisa lebih nyaman, tetapi jika dengan motor atau angkutan umum lain, anak perlu ekstra dijaga. Cuaca, iklim, dan kondisi jalan raya bisa mengganggu pernapasan anak. Oleh karena itu, tetap pentingkan kesehatan anak. Waspada pula dengan kecelakaan lalu untas, konsentrasi kita kepada si kecil mungkin lebih utama.

d. Penting sekali bagi orang tua untuk menyortir tujuan kita menyekolahkan anak. Hal ini akan membentuk harapan atas apa yang akan didapat anak di sekolah. Apakah kita ingin memperkenalkan kepada anak tentang nuansa kehidupan di luar rumah. Visi dan misi ini juga akan membentuk skala prioritas orang tua dalam mencari sekolah untuk anaknya, termasuk hal apa yang harus dikompromikan. Karena tentu saja tidak ada sekolah yang sempurna dalam memenuhi segala persyaratan dan harapan kita sebagai orang tua. Oleh karena itu, orang tua sebaiknya menimbang betul kemarnpuannya dalam menunjang pendidikan anak di rumah.

e. Orang tua harus melakukan kunjungan ke sekolahsekolah yang menjadi pilihan untuk anaknya supaya dapat melihat sendiri keadaan sekolah itu, menangkap suasana, serta bertanya jawab langsung dengan pihak sekolah atau orang tua dan murid di sekolah tersehut. Saat melakukan kunjungan ini, datanglah sendiri terlebih dahulu agar dapat leluasa 
mengobservasi keadaan sekolah dan bertanya jawab. Jika kemudian orang tua merasa cocok dengan apa yang dilihat dan didengarnya, rencanakan kunjungan kedua bersama anak agar orang tua bisa melihat, apakah anak merasa cukup nyaman di sekolah itu atau tidak. Meskipun demikian, perlu diingat bahwa kemampuan setiap anak untuk beradaptasi di lingkungan baru berbeda. Jika anak menangis dan kelihatan takut, bukan berarti bahwa sekolah itu buruk dan tidak cocok untuknya. Beberapa informasi penting yang perlu dicari mengenal sekolah anak usia dini atau preschool adalah hal-hal sebagai berikut.

1. Program.

Para orang tua bisa dengan leluasa bertanya tentang konsep dan sistem pengajaran di suatu sekolah; apakah kreativitas, pemikiran kritis, dan keterlibatan aktif murid dianggap penting? Apakah perbedaan kemampuan tiap anak diakomodasi dengan baik? Seimbangkah antara kegiatan akademis (intrakurikuler) dan kegiatan ekstrakurikuler? Intinya, program sekolah yang baik harus dapat memberikan pendidikan sekaligus pengajaran kepada rnuridnya.

2. Guru.

Tanyakanlah kualifikasi dan latar belakang pendidikan guru-guru yang mengajar di sekolah tersebut. Guru yang memahami psikologi dan masalah perkembangan anak tentunya akan 
lebih mampu mendidik dan mengajar muridnya dibandingkan dengan guru yang hanya sekadar menyampaikan materi pelajaran sesuai dengan kurikulum. Akan lebih baik lagi jika kita bisa menangkap suasana interaksi di antara para guru di sekolah itu. Sebuah tim yang solid dan kompak tentunya akan menghasilkan proses pengajaran dan pendidikan yang konsisten.

3. Fasilitas.

Pada dasarnya untuk dapat dikatakan memiliki fasilitas yang memadai, sebuah sekolah tidak perlu dilengkapi dengan kolam renang dan alat permainan yang canggih atau diimpor dan luar negeri. Meskipun ada preschool yang memang menyediakan kolam renang untuk sesi bermain di air, yang terpenting bahwa sekolah itu memiliki fasilitas dengan standar kebersihan, keamanan, dan kenyamanan yang baik untuk anak. 


\section{KESIMPULAN}

Banyak sekolah yang menyatakan diri sebagai sekolah unggul yang berkualitas dengan menjual gedung dan fasilitas pendidikan yang lengkap atau memiliki jargon sebagai sekolah berstandar internasional. Padahal. bisa jadi pembelajarannya tidak sebaik gedung atau jargon yang dieluelukan. Oleh karena itu, pemilihan sekolah sebagai lembaga yang memberikan layanan pendidikan anak usia dini menjadi hal yang harus diperhatikan mengingat masih banyak sekolah yang belum menerapkan pembelajaran yang sesuai dengan pertumbuhan dan perkembangan anak. Dengan demikian, orang tua bisa memilih sekolah dengan berorientasi belajar dengan semua kecerdasan. Orang tua bisa mencatat dalam catatan perkembangan anak bahwa selama rentang waktu di sekolah hari itu, masing-masing anak harus menerapkan permainan keseimbangan unik gaya belajarnya. Setiap orang tua menginginkan yang terbaik bagi anaknya, tetapi sebagian besar tidak pernah dibimbing bagaimana menciptakan lingkungan esensial guna menggali seluruh kemampuan awal anak sejak dini. 


\section{SOAL-SOAL}

1. Jelaskan yang di maksud dengan sekolah dan peluang masa depan?

2. Sebutkan bagaimana menciptakan sekolah yang berpeluang masa depan tersebut?

3. Bagaimana porsi pembelajaran dan kurikulum yang diterapkan pada sekolah masa depan?

4. Adakah kaitan visi dan misi yang dibuat sekolah dengan sukses tidaknya menghantarkan sekolah berpeluang masa depan? 


\section{DAFTAR PUSTAKA}

Agbarachi Opara, J., \& Silas Oguzor, N. (2011). Inquiry Instructional Method and the School Science Currículum. Current Research Journal of Social Sciences, 3(3), 188-198.

Aritonang, S. D., Hastuti, D., \& Puspitawati, H. (2020). Pengasuhan Ibu, Keterlibatan Ayah Dalam Pengasuhan, dan Perkembangan Kognitif Anak Usia 2-3 Tahun di Wilayah Prevalensi Stunting. Jurnal IImu Keluarga \& Konsumen, 13(1), 38-48.

Maoto, S. (2014). Creating a child friendly psychosocial learning environment in mathematics: $A$ case of problem solving in grade 6. Mediterranean Journal of Social Sciences, 5(23), 1048-1055. https://doi.org/10.5901/mjss.2014.v5n23p1048

Mouri, Kousuke; Uosaki, Noriko; Ogata, H. (2018). Learning Analytics for Supporting Seamless Language Learning using E- book with Ubiquitous Learning System. Educational Technology \& Society, 21(2), 150-163. https://doi.org/10.1007/springerreference_226192

Nuraeni, L., Andrisyah, A., \& Nurunnisa, R. (2019). Efektivitas Program Sekolah Ramah Anak dalam Meningkatkan Karakter Anak Usia Dini. Jurnal Obsesi: Jurnal Pendidikan Anak Usia Dini, 4(1), 20. https://doi.org/10.31004/obsesi.v4i1.204

Wadjdy, F. (2017). Education in Border Regions. TARBIYA: Journal of Education in Muslim Society, 4(2), 224-231. https://doi.org/10.15408/tjems.v4i2.6982 


\section{Bab IV Guru Zaman Now}

Berdasarkan pengalaman, baik ketika kita masih anakanak yang masih duduk di bangku sekolah maupun sekarang Ketika kita sudah remaja bahkan dewasa. Hal yang menjadi patokan pertama menarik perhatian peserta didik dalam belajar ialah pesona seorang guru. Jadi, mata pelajaran bukan daya tarik utama. Sampai-sampai muncul ungkapan, "Supaya gampang dalam menghadapi semua mata pelajaran, maka pertama-tama sukai dulu guru/pengajarnya". Begitulah kira-kira ungkapan yang sering kita dengar selama ini. Jika ditelisik lebih dalam, ungkapan tersebut memang sebuah kenyataan atau benar adanya. Setiap peserta didik pasti menyukaí sosok guru yang menarik. Guru tersebut selalu dekat dengan kehidupan peserta didiknya. Terlebih, di era generasi Z, guru harus bisa mengimbangi karakter peserta didik masa kini. Secara usia, guru boleh sudah melewati masa kekinian. Namun demikian, konsep kekinian yang dimaksucl bukan berarti guru mesti bersikap seperti anak-anak, melainkan mampu memberi contoh sesuai nalar anak muda. Artinya, hal-hal kekinian diramu sedemikian rupa sehingga tetap berada di batas kewajaran. Dalam istilal, lain, hal ini disebut gaul tapi sopan.

Sebagai contoh, mengapa pelajaran berhitung terkadang tidak disukai peserta didik zaman sekarang? Mengapa pelajaran tentang membuat penelitian cukup menarik perhatian peserta didik? Atau, mengapa tugas 
fotografi lebih membuat kids zaman now tertarik? Menurutku, semua itu terjadi karena kekakuan seorang guru dalam mengajar. Bukan hendak membandingkan dengan mata pelajaran lain, tetapi begitulah kenyataannya. Pelajaran berkaitan dengan angka lebih sedikit diminati daripada mata pelajaran yang membutuhkan kreativitas dalam berkarya. Hal ini menunjukkan bahwa guru memegang peranan penting dalam proses pembelajaran.

\section{A. Menjadi Guru Masa Kini}

Menjadi guru masa kini juga harus supel, lucu, dan tidak mudah emosi dalam menghadapi peserta didik di kelas. Kalaupun ada peserta didik yang nakal, usahakan jangan terpancing amarah. Justru, kita harus bisa menahan emosi dan memberikan nasihat secara lembut kepada peserta didik yang bersangkutan. Kids zaman now tidak menyukai kekakuan, terutama guru yang hanya memedulikan penyampaian materi tanpa memikirkan tingkat kepahaman peserta didiknya. Lagi-lagi berdasarkan pengalaman pribadi, aku sering mencari informasi terkait hal-hal atau istilahistilah yang tengah populer di masyarakat. Aku berusaha menyelipkannya dalam kegiatan pembelajaran. Hal ini bertujuan supaya aku bisa dekat dengan kids zaman now. Untungnya, aku menjadi pengajar bahasa Indonesia sehingga relatif mudah dalam memasukkan istilah-istilah kekinian di kegiatan pembelajaran. Selama hampir 7 tahun mengajar, aku boleh dibilang tidak mengalami kendala yang cukup berarti dalam urusan ini. Bahkan, peserta didik justru menyukai caraku mengajar yang serius, tetapi santai. 
B. Menerapkan Inovasi Belajar Kreatif

Inovasi belajar kreatif juga harus diterapkan oleh pendidik di era sekarang. Demi menemukan inovasi-inovasi kreatif dalam mengajar, aku pernah menghadiri lomba yang di situ, guru diharuskan mempresentasikan inovasi belajar yang unik sekaligus kreatif di Sampang, Madura. Pada momen tersebut, aku juga mengambil beberapa ilmu dan guru-guru lain. Hal itu kujadikan bahan untuk membuat inovasi pembelajaran sederhana, tetapi bermanfaat bagi peserta didik di sekolah.

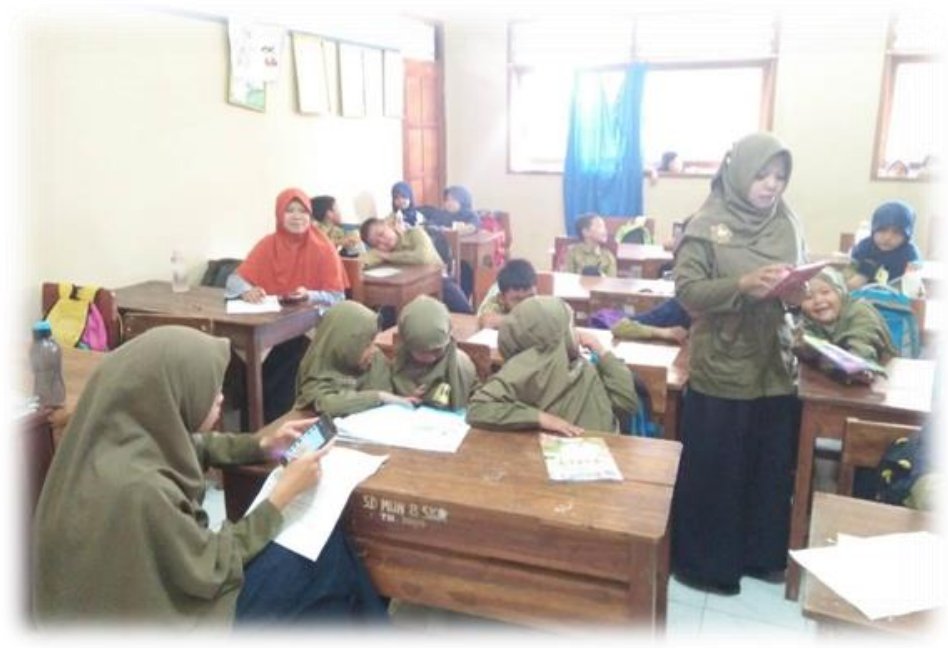

Gambar 9. Menggalakkan Program Literasi di Sekolah

Inovasi yang dilakukan sedikitnya mencakup dua hal. Pertama, program sebulan membaca satu buku. Inovasi ini diterapkan dan masih berlangsung hingga hari ini. Caranya cukup mudah, yaitu setiap peserta didik harus mengambil 
secara acak buku yang ada di perpustakaan sekolah lalu dibaca sampai selesai dalam waktu satu bulan. Setiap akhir bulan, dipilih beberapa murid untuk menceritakan ulang atau mempresentasikan hal-hal yang telah dibaca di masingmasing kelas.

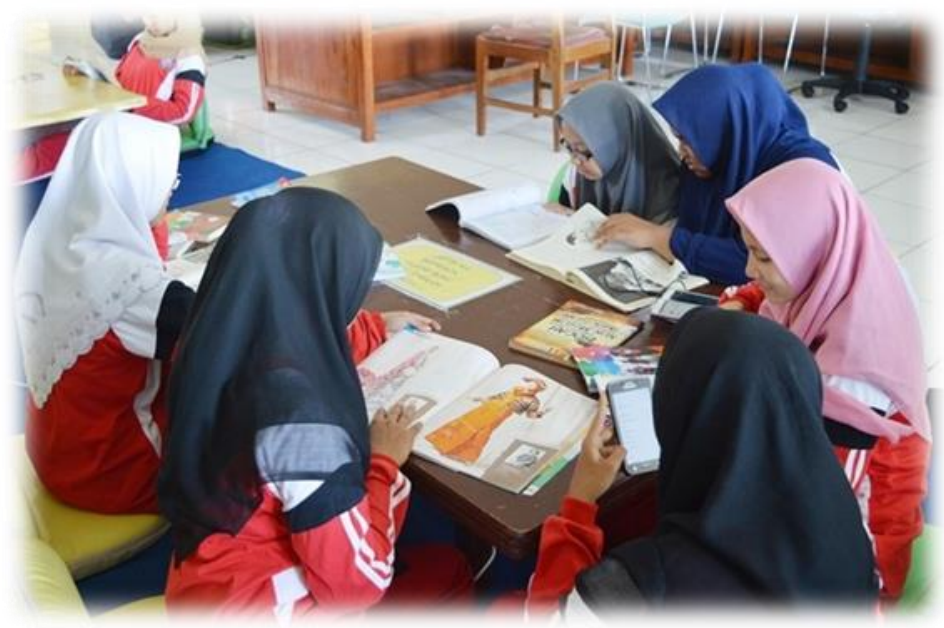

Gambar 10. Telaah Buku Bagi Siswa

Mewajibkan menelaah satu buku dalam satu bulan cukup membantu menyuntikkan semangat membaca kepada peserta didik di sekolah. Pada dasarnya, tidak sedikit di antara mereka yang suka membaca buku. Meskipun ada tugas membaca satu buku dalam satu bulan, rupanya peserta didik di sekolah ada yang melakukan lebih dari itu. Hal ini cukup membuatku babagia ketika melihat semangat mereka mencan ilmu melalui buku masih menyala. Tak heran jika aku 
pun menjadi ikut bersemangat membaca karena melihat peserta didik yang antusias. Bukan hanya meminjam dan perpustakaan sekolah, mereka juga saling tukar-menukar buku pribadi. Jadilah kami saling bertukar ilmu pengetahuan melalui buku bacaan.

Melihat semangat peserta didik membaca, peserta didikpun yang lainnya juga ikut tergerak untuk membeli buku-buku ketika berkesempatan pergi ke luar kota. Setelah membaca seluruh isinya, aku meminjamkan buku buku itu ke beberapa peserta didik untuk dibaca. Begitulah seterusnya secara bergiliran. Maksud kegiatan ini adalah setiap peserta didik harus bisa menulis satu kejadian menarik dalam setiap hari. Artinya, setiap peserta didik wajib mempunyai satu buku khusus untuk dituliskan satu peristiwa paling unik sepanjang hari dalam bentuk beberapa paragraf narasi. Hal ini semacam menulis buku harian (diary). Adapun buku yang digunakan tidak perlu bagus, tetapi hendaknya cukup tebal. Tujuanku mengajak peserta didik menulis kisah kesehariannya ialah untuk menjadikan mereka generasi kreatif dalam membuat tulisan. Tujuan lainnya adalah melatih kebiasaan mereka menuangkan peristiwa unik dalam bentuk tulisan.

Dalam kurikulum 2013 versi revisi 2017, peserta didik dituntut sering melakukan kegiatan literasi. Adapun maksud literasi di sini bukan hanya membaca dan menulis, tetapi juga interaksi sosial. Sebagai contoh, peserta didik pergi ke pasar melihat kegiatan tawar-menawar, melakukan penjelajahan dalam kegiatan Pramuka, dan sebagainya. Tujuannya, tentu saja untuk membaca (mengamati) berbagai peristiwa yang 
terjadi di lingkungan sekitar untuk selanjutnya dianalisis. Dalam hal ini, analisis bisa mencakup struktur, makna, atau apa pun yang berhubungan dengan pembelajaran yang tengah dipelajari.

\section{Menghilangkan Punisment}

Langkah ini boleh jadi cukup kontroversial. Sebab, jika punisment atau hukuman di sekolah dihapus, maka akan berdampak buruk bagi diri peserta didik. Hal ini juga akan berpengaruh terhadap wali kelas yang semakin repot mengurus peserta didik bermasalah. Seandainya punisment benar-benar dihapus, peserta didik tidak lagi berpikir ulang sebelum melakukan berbagai pelanggaran.

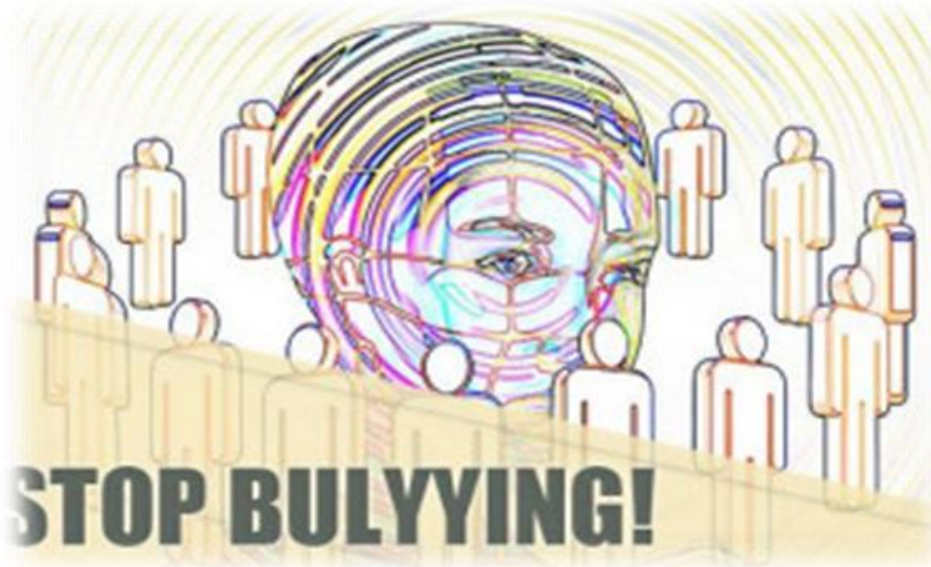

Gambar 11. Mencegah Bulyying

Sehubungan dengan itu, perlu ditegaskan bahwa menghilangkan punisment yang dimaksud di smi bukan 
berarti menghilangkan sama sekali, melainkan mengganti dengan hukuman lamnnya yang lebih mendidik. Sebelum membahas lebih jauh, patut diketahui bahwa punisment adalah salah satu bentuk hukuman bagi peserta didik yang telah melakukan kesalahan tertentu sehingga tidak boleh masuk sekolah selama beberapa hari. Lama punisment bagi peserta didik disesuaikan dengan kadar kesalahan yang telah dilakukannya. Tujuan pemberian punisment adalah membuat peserta didik lebih disiplin dalam mematuhi peraturan sekolah.

Pemberian punisment, selain mengurangi waktu belajar, juga berpotensi memunculkan kesempatan peserta didik menimbulkan beberapa masalah selaniutnya. Terlebih, kids zaman now pasti semakin senang jika dilarang masuk sekolah. Maksud hati ingin menghukum, peserta didik justru menikmati hukuman itu. Hal ini benar-benar pernah terjadi. Menjadi pendidik zaman sekarang tidaklah mudah. Permasalahan yang dihadapi jauh lebih kompleks daripada peserta didik belasan tahun silam. Oleh karena itu, marilah kita sating bergandengan tangan untuk membimbing generasi muda. Bukankah kemajuan sebuah bangsa berawal dan kualitas generasi mudanya? Inilah tugas berat bagi pendidik dan orang tua yang wajib kita pikul bersama.

\section{Sekolah Zaman Now}

Seperti halnya profesi lainnya, guru juga memiliki tantangan tersendiri. Tertebih, bagi guru di zaman yang serba ajaib. Tak usah kaget apalagi heran dengan situasi sekarang yang jauh berbeda dengan zaman sekotah dulu. Selain 
zamannya berbeda, siswa-siswanya juga berlainan. Begitu pula lingkungannya. Jadi, jangan berharap masih sama seperti zaman dulu. Kita mungkin sudah tahu betapa rumitnya membuat Rencana Pelaksanaan Pembelajaran (RPP) di kampus atau sekolah.

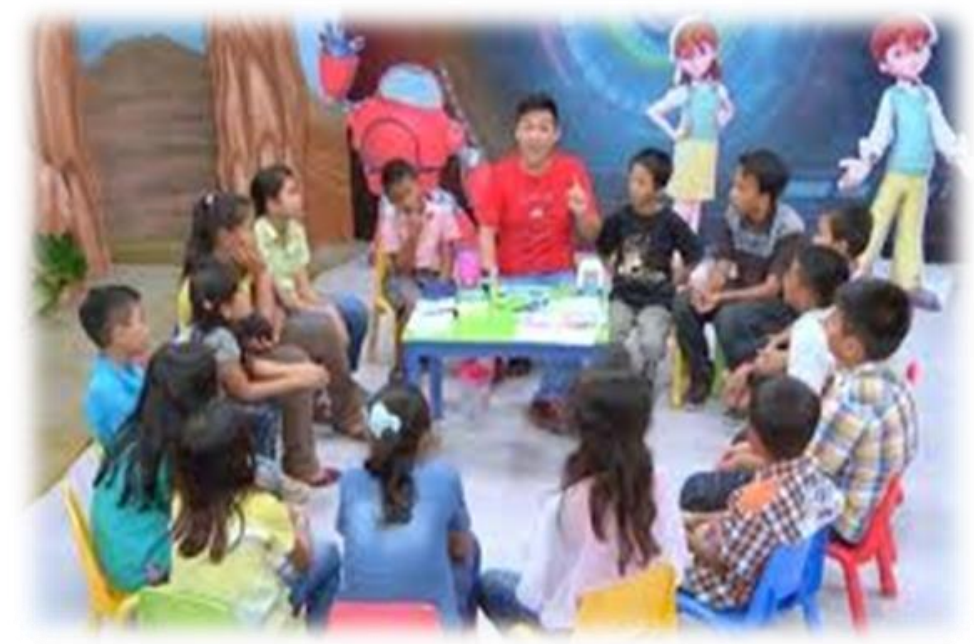

Gambar 12. Pola Pembelajaran Zaman Now

Masih ingatkah kita bagaimana mempersiapkan perangkat pembelajaran saat kuliah di kampus dulu? Meskipun tidak belajar di fakultas atau jurusan keguruan, kamu tetap wajib tahu akan hal ini. Hal-hal yang dipelajari di kampus, belum ada apa-apanya dengan kenyataan di lapangan. Berapa banyak RPP yang harus dipersiapkan saat belajar di kampus dulu? Paling banyak satu atau dua RPP untuk satu pertemuan praktik mengajar. Kenyataan di 
sekolah, tidak jarang RPP satu tahun harus dikerjakan secara utuh dan lengkap, mulai dari A hingga Z. Hal itu hanya jika kita memegang satu mata pelajaran untuk satu kelas atau jenjang di sekolah. Lain cerita jika mendapat tugas mengajar beberapa mata pelajaran ataupun lebih dan satu tingkatan kelas. Hitung dan kalikan saja, yakni RPP untuk satu semester hingga satu tahun dikalikan jumlah pelajaran yang dipegang dan total kelas yang diajar.

Di tengah tidak idealnya RPP, temyata hal ini menjadi peluang bagi sejumlah orang yang menawarkan "jasa" membuatkan RPP. Nyatanya, tak hanya RPP yang ada jasanya. Silabus, analisis kompetensi dasar, program semester, hingga program tahunan pun jadi sasaran. Hanya saja, tidak jarang kualitas "jasa” ini jauh dari kata standar, apalagi maksimal. Hal ini tak bisa disalahkan sepenuhnya. Namanya juga orang melihat peluang usaha. Bagi guru yang rajin, perangkat pembelajaran tentu bukan persoalan utama. Lorang tuaran akhir tahun ajaran biasanya digunakan untuk mempersiapkan pembelajaran selama satu tahun benikutnya. Data-data lama dorang tuaka kembali, ditata ulang, dan diperbaiki. Pembelalaran pun disesuaikan dengan kunikulum baru yang tengah berlaku. Mereka inilah makhluk pitihan yang wajib untuk diberdayakan, dihormati, diminta ilmunya, dan jangan disakiti.

Nyatanya, masih banyak guru yang suka menundanunda menyiapkan pembelajaran selama satu tahun. Silabus masih berupa hasil unduh dan salin. RPP pun hasil dan menyalin dan mengubah seadanya sehingga lupa menyesuaikan jumlah jam dan waktu pembelajaran. 
Menyiapkan perangkat pembelajaran memang tugas seorang guru. Maka, tidak wajar jika ada guru yang tidak mengerti hal ini. Tak pantas guru enggan belajar dan fakta di lapangan soal administrasi dan perangkat pembelajaran. Lebih tidak wajar kalau masih terus dibebani beragam jenis kewajiban administrasi lainnya. Urusan guru ideal atau tidak akhirnya menjadi relatif. Kewajiban yang terkadang lebih rumit secara tidak langsung perlahan mengikis idealisme untuk menjadi guru yang mumpuni dan maksimal. Kewajiban tidak jarang terkikis dan dikesampingkan oleh satu dua alasan. Di lapangan, perangkat pembelajaran bukan hanya soal silabus, analisis kompetensi, program tahunan, program semester, dan RPP.

Tidak hanya soal administrasi dan perangkat pembelajaran. Anak-anak masa kini berbeda jauh dengan orang tua atau guru-guru mereka dulu di masa mudanya. Mereka butuh perlakuan yang berbeda sama sekali dan perhatian khusus. Anak-anak ini berasal dan orang tua, lingkungan sosial, dan latar belakang berlainan satu sama lain. Hal ini sudah menjadi sesuatu yang wajar. Luar biasanya, perbedaan ini semakin kompleks seiring perkembangan situasi masyarakat masa kini.

Anak-anak zaman sekarang yang lahir masa gelimang teknologi dan gawai, sejak kecil mengalami pola asuh berbeda dibanding para pendahulunya. Perubahan dan perbedaan pola asuh ini kemudian memberi ciri khas bagi mereka. Di satu sisi, anak-anak ini yang dikenal juga sebagai generasi Z-bisa dengan mudah mencari dan mendapatkan informasi dengan cepat, tepat, dan dan sumber mana pun 
tanpa terhalang waktu dan tempat. Keuntungan ini jelas membuat semuanya serba cepat dan lebih mudah. Namun, jangan lupa bahwa kemudahan dalam mendapatkan informasi ternyata tidak selalu berbanding positif dengan manfaatnya. Kemudahan ini bisa memicu masalah lain jika sumber informasinya tidak tepercaya (hoax) atau bahkan menjadi sebab munculnya masalah sosial lain. Misalnya, informasi tentang kriminal bisa memicu siswa untuk mencobanya sendiri. Informasi yang tak jelas dapat memicu perdebatan di kalangan anak-anak sehingga terjadi perang pendapat di dunia maya.

Semakin mahir anak-anak dengan teknologi, kian mudah bagi mereka melakukan beragam hal. Hal inilah yang kemudian membuat anak-anak menjadi pribadi multitasking, yakni bisa melakukan beberapa hal sekaligus dalam satu waktu (Chin \& Chen, 2013). Sisi baiknya, mereka mampu membuat segala sesuatu menjadi lebih cepat, efektif, dan efisien. Namun, di sisi lain, hal ini bisa juga memicu ketergantungan akan teknologi. Ketergantungan yang terus menerus lambat laun akan memupuk bibit kemalasan. Bukan hanya malas, sifat multitasking juga bisa membuat siswasiswa kehilangan fokus. Akibatnya, mereka menjadi mudah teralihkan oleh hal lain sebelum bias menyelesaikan satu hal. Kalau satu hal tidak selesai, maka sesuatu yang lain juga tidak akan tergarap secara maksimal.

Dalam pembelajaran di sekolah, anak-anak yang memiliki kreativitas dan rasa ingin tahu sangat tinggi cenderung memilih semua hal berbasis teknologi. Jika dipenuhi, semua kegiatan pendidikan dan pembelajaran akan 
berbasis teknologi. Mereka yang memang sudah mahir dalam gelimang teknologi merasa lebih mudah belajar dan menemukan hal baru lewat internet. Nyatanya, teknologi bukan segalanya. Memang benar, nyaris semua hal-saat inibisa dengan mudah didapat dan teknologi. Namun, tetap saja ada yang tidak bisa dipenuhi dan teknologi. Contohnya adalah kehidupan sosial yang hanya bisa diperoleh secara nyata dan interaksi langsung sesama manusia melalui pola sederhana tatap muka dan berbicara secara langsung. Teknologi memang membantu, tetapi tetap saja tak bisa mengambil alih kegiatan sosial secara keseluruhan (Atif, Mathew, \& Lakas, 2015).

Hidup di tengah lingkungan sekolah sekarang dengan anak anak yang superkreatif adalah tantangan tersendiri. Ada banyak hal yang tak bisa clipungkiri pasti berubah dan terus berkembang. Perubahan bukan berarti bermakna negatif. Sebab, sisi dinamis hidup berasal dan perubahan. Hanya saja, perubahan yang tidak terkendali tanpa nilai yang jelas juga bisa berakibat buruk. Berikut ini perspektif guru, orang tua dan masyarakat pada peserta didik di sekolah.

\section{Nakal $=$ Kreatif}

Tidak ada guru yang menghendaki siswanya gagal. Sederhananya, tak ada guru yang ingin siswa-siswanya mendapat nilai jelek. Hal ini sering membuatku benar benar ingin menangis lantaran merasa sesak. Aku benarbenar tidak pernah berniat pelit memberikan nilai. Namun, kalau mereka sendíri tidak ada usaha untuk bisa mendapatkan nilai baik, rasanya nilai minimalis lebih pantas diberikan. Mungkin, nilai mereka jelek di (mata 
pelajaran) yang kuajarkan, tetapi boleh jadi baik di bidang lain. Selalu kukatakan pada diri teknologi memang terlihat keren. Namun, jangan lupa bahwa kehidupan tidak hanya ditunjang oleh teknologi. Patut diingat bahwa masih ada kehidupan bermasyarakat dan bersosialisasi yang patut diperhatikan oleh semua pihak. Boleh saja anak muda masa kini tampil keren dengan teknologi tercanggih dan terbaru. Sah-sah saja mereka ahli menguasai beragam produk teknologi. Namun, apalah artinya semua itu kalau mereka lupa cara bersikap?Apalah arti itu semua bila mereka buta dalam bersikap terhadap diri sendiri, orang lain, dan lingkungan sekitar? Manusia budak teknologi bisa segera menjadi kenyataan bila guru dan orang tua tidak paham dan tahu cara melawannya sebelum benar-benar terjadi.

\section{Zaman Old vs Zaman Now.}

Menurut data demograijs tahun 2010, disebutkan bahwa ada sedikitnya 19 persen penduduk Indonesia yang berusia di bawah sepuluh tahun. Adapun 37 persen penduduk berusia di bawah 20 tahun sedangkan pada kisaran setengab populasi berusia di bawah 30 tahun. Dari jumlah ini, jika total penduduk Indonesia adalah 258 juta orang sebagaimana diproyeksikan Badan Pusat Statistik pada tahun 2016, artinya penduduk Indonesia di bawah usia 30 tahun saat ini-yakni kategori generasi Zmencapai angka sekitar 90-I00 juta orang. Sebuah angka yang relatif besar sebagai bagian dari generasi usia produktif. Melihat jumlah sebesar itu, maka keberadaan anak-anak masa kini atau generasi $Z$ adalah potensi besar 
dalam menunjang pertumbuhan ekonomi nasional. Dan data ini, sekitar 58 juta di antaranya adalah pelajar sekolah dengan rincian sekitar 8 juta siswa SMA/sederajat dan 50 juta siswa SD hingga SMP/sederajat. Pertanyaannya, apa yang harus dilakukan dan dipersiapkan untuk siswa sekarang yang akan menjadi pemimpin masa depan pada kisaran tahun 2040 ke atas. Sebagai generasi yang lahir dan dibesarkan teknologi dan internet, karakter generasi $Z$ adalah aktif berkomunikasi menggunakan ponsel pintar (smart phone), memiliki ketergantungan tinggi terhadap gawai dan internet, multitasking, memiliki ruang pribadi yang tertutup rapat, serta menyukai tantangan. Boleh dibilang, generasi yang lahir setelah tahun 2000-an memiliki rasa percaya diri yang sangat tinggi.

Bukan hanya memiliki karakteristik unik, cita-cita mereka akan masa depan juga tergolong kurang lazim. Mereka sudah mulai menyingkirkan televisi sebagai saah satu sumber berita karena lebih mengedepankan mencari informasi yang bersifat pribadi, seperti YouTube atau media sosial. Akibatnya, profesi seperti youtuber, vlogger, bloger, gamer, selebgram, bahkan hacker dan penambang bitcoin mulai menjadi pilihan karier masa depan mereka.

Bagi siswa-siswa generasi Z, ragam peralatan elektronik dan gawai sudah menjadi hal blasa dan merupakan sebuah kelaziman. Maka, bukan lagi aneh jika kita menemukan anak-anak kecil sudah paham serta terampil menggunakan beragam perangkat elektronik dan gawai, 
seperti komputer, laptop, ponsel pintar, dan sebagainya. Tak hanya mahir, mereka juga sangat terampil memanfaatkan atau bahkan memproduksi dan merekayasa beragam perangkat teknologi, contohnya media sosial seperti Facebook, Instagram, YouTube, Snapchat, Viog, Line, Telegram, Twitter, dan lain-lain. Tidak jarang mereka memiliki ikatan begitu erat dengan media sosial sehingga lebih memilih membagikan kegiatan pribadi mereka lebih dulu di media sosial daripada orang-orang di sekitarnya.

Bagaimana dengan media cetak? Sudah tak terhitung berapa banyak media cetak seperti koran dan majalah yang gulung tikar dan beralih menjadi media dalam jaringan demi memenuhi kebutuhan dan tren masa kini. Akibatnya, surat kabar, buku, dan televisi mulai hanya dinikmati oleh generasi tua. Format buku cetak pun pelan tapi pasti digantikan oleh bentuk digital dalam format e-book dan pdf. Karenanya, ketergantungan akan gawai dan perangkat sejenisnya kian meningkat.

Perubahan yang terjadi pada siswa-siswa masa kini mau tidak mau berpengaruh pula terhadap pola asuh orang tua ataupun guru. Kedua pihak tersebut dituntut mampu mengimbangi perilaku anak-anak zaman sekarang. Atau paling tidak, orang tua dan guru mampu memenuhi kebutuhan siswa mengenai fasilitas zaman sekarang.

Hal yang jadi pertanyaan, apakah guru dan orang tua bisa dengan mudah menyesuaikan din dengan perubahan pola asuh ini? Nyatanya, belum semua dan mereka mampu mengikuti perubahan dengan berbagai alasan. 
Tidak jarang kondisi inilah yang menyebabkan siswa mencari pemenuhan kehausan mereka akan teknologi, gawai, dan informasi dan luar, di antaranya warung internet. Tempat ini telah menjadi salah satu lokasi favorit bagi anak-anak zaman sekarang untuk datang dan berkumpul. Selain warung internet, area wifi juga menjadi salah satu tempat favonit bagi mereka untuk menongkrong.

Menjadi guru dan orang tua zaman now harus dihadapi sebaik mungkin. Tak ada guru ataupun orang tua yang bisa menghindari hal ini. Jika rasa ingin tahu siswa akan dunia dan teknologi semakin besar maka sudah menjadi tanggung jawab orang tua dan guru untuk memiliki keingintahuan yang lebih besar lagi. Jika kreativitas siswa kian makin menjadi, sudah sewajarnya orang tua dan guru lebih kreatif. Tak ada yang bisa mencegah perubahan yang dialami anak-anak zaman sekarang. Tugas orang tua dan guru sebenarnya bukan menyaingi mereka. Rasa ingin tahu yang tinggi, kreativitas, multitasking, efisiensi pekerjaan, sikap haus akan informasi, serta kemahiran menggunakarì teknologi yang harus dimiliki oleh orang tua dan guru zaman sekarang dapat dianggap sebagai rem. Dalam hal ini, rem adalah sebuah cara untuk mengarahkan (mengontrol) anak-anak zaman sekarang agar tetap berada pada jalur yang tepat. Teknologi ibarat pedang bermata dua. Jika dimanfaatkan secara benar dan oleh orang yang tepat maka bisa didapatkan manfaat luar biasa untuk umat manusia. Sebaliknya, jika teknologi dimanfaatkan oleh orang yang 
salah dan dengan cara keliru, efek buruknya akan bisa lebih menakutkan dan yang pernah dibayangkan.

Kesimpulannya, jadilah guru yang menerima beragam bentuk kreativitas siswa ataupun ragam reaksi orang tua mereka. Demikian pula jadilah orang tua yang berprasangka baik dan selalu mengedepankan komunikasi alih-alih marah-marah tidak jelas di sekolah tanpa mencari tahu lebih dulu sesuatu yang benar-benar terjadi. Jika siswa bisa menjadi kids zaman now, orang tua juga harus mampu berperan sebagai parent zaman now.

\section{Guru Gaul vs. Anak-Anak Zaman Sekarang}

Punya media sosial apa saja? Aku follow ya? Nanti follow balik, Oke?" Setelah terjadi pembicaraan itu, mereka saling menyebutkan deretan nama media sosial yang sedang menjadi tren dan mempunyai banyak pengguna di luar sana. Peran media sosias memang bukan lagi sebatas sarana menjalin pertemanan. Bagi siswa-siswa ini, media sosial juga menjadi tempat menunjukkan eksistensi din. Semakin aktif di media sosial dengan banyak memuat foto dan status, maka akun tersebut makin keren. Anehnya, siswa menganggap media sosial sebagai ruang pribadi. Namun, ruang pribadi yang seharusnya tertutup rapat justru dipenuhi tulisan dan keluh kesah di media sosial yang dibaca orang banyak. Aku sendiri bukan termasuk tipe orang yang terlalu sering membuka akun media sosial. Atau, mungkinkah masa alay dan lebay pada diriku sudah lewat? Boleh jadi begitu. Anak-anak zaman sekarang menggunakan 
sejumlah istilah aneh. Entah pelesetan bahasa Indonesia ataupun istilah asing yang memang tidak familiar bagiku saat berada di kelas. Beberapa kali aku mencoba tak ambil pusing. Namun, mereka ternyata sangat sering menggunakan istilah aneh. Secara iseng, aku pun menelusuni satu per satu akun media sosial milik siswa yang sudah menjadi temanku di akun media sosial. Aku seketika merasa berada di dunia yang benar-benar asing dan baru. Sebab, bahasa yang mereka gunakan sungguhsungguh ajaib dan baru kuketahui. Dari situlah, aku merasa jauh tertinggal dari siswa-siswa yang bahkan baru belajar secara mandiri ini. Bukan hanya mempunyai akun media sosial, sebagai orang tua dan guru masa kini, kita juga perlu tahu batasan dalam bermedia sosial serta bijak dalam menggunakannya. Minimal, kita bisa menahan din dalam mengunggah informasi di akun media sosial yang diikuti oleh siswa. Gaul boleh saja, tetapi jangan keterlaluan. Gaul itu penting, tetapi bukan berarti mudah kagum terhadap semua informasi yang berseliweran di media sosial. Sekalipun gaul, jangan sampai latah ikutikutan, apalagi lupa cara bersikap. Lebih dan itu, jangan sampai guru menyebarkan hal-hal negatif atau kebohongan yang bisa merusak.

\section{Gen $\mathrm{Z}=$ Generasi Instan}

Salah satu ciri utama generasi $Z$ ialah akrab dan cakap dalam memanfaatkan teknologi. Hal ini jelas memudahkan segala hal dalam hidup mereka. Hanya saja, ada sisi negatifnya, yakni mereka menjadi pribadi yang kurang sabar. Artinya, mereka sulit menghargai 
proses dan menyukai segala hal yang bersifat serba instan. Kemajuan teknologi memang memudahkan kehidupan manusia. Mesin pencan, media sosial, dan beragam aplikasi lain sebenarnya-secara tidak langsung-melatih manusia menjadi makhluk yang manja. Segala sesuatu dipermudah dan memang seperti itulah tujuan diciptakan dan dikembangkannya teknologi. Namun demikian, ada sisi jelek dari hal itu, yakni manusia menjadi semakin malas dan manja. Salah satu contohnya, generasi ini kurang menghargaj proses. Adakalanya, mereka bersikap tidak memedulikan cara asalkan bisa mendapatkan hasil yang diharapkan. Semua ingini dilakukan dalam waktu singkat dan cepat. Beberapa dan mereka bahkan menjadi pribadi yang multitasking. Mereka bisa melakukan beberapa hal sekaligus dalam satu waktu. Sisi positifnya, mereka bisa melakukan sesuatu secara efektjf dan efisien. Hanya saja, kebiasaan serba instan ini merambah berbagai hal sehingga menjadikan merelca tidak sabaran dan enggan menghargai proses.

Sesuatu yang instan indah dilihat. Tak perlu lagi menunggu terlalu lama ataupun menanti tanpa kepastian. Sebagai catatan, sesuatu yang didapat secara instan maka lebih cepat hilangnya. Hal inilah yang terkadang belum benar-benar dipahami oleh generasi $Z$ atau anak-anak masa kini. Masalahnya saat ini bukan memberi label mereka sebagai generasi instan atau bukan, melainkan mencegah ataupun melakukan penanggulangan jika hal tersebut benar terjadi. Dengan 
beragam fasilitas yang serba modern, lengkap, dan cepat, maka tak bisa dipungkiri jika anak-anak zaman sekarang tumbuh dengan prinsip, "Kalau bisa dorang tuaat mudah, kenapa dipersulit?" Inilah yang harus disadari benar oleh orang tua ataupun guru. Bukan berarti hidup harus dipersulit jika memang ada yang lebih mudah. Namun, siswa perlu diberi pendidikan untuk bisa menikmati setiap proses apa pun. Dengan demikian, mereka kelak bisa lebih menghargai setiap proses.

Pembelajaran dengan teknologi penting dilakukan. Bukan hanya guru, orang tua juga mempunyai kewajiban untuk mahir memanfaatkan teknologi dalam menunjang pendidikan. Kalau pendidik tidak memanfaatkan teknologi maka akan dianggap ketinggalan zaman. Jika guru enggan menggunakan teknologi maka bisa adi pembelajaran tak lagi sesuai dengan situasi dan keadaan masa kini. Apakah teknologi saja sudah cukup? Kenyataannya tidak demikian. Pembelajaran berbasis teknologi saja belum cukup untuk mempersiapkan generasi Z di masa depan. Faktanya, kehidupan tidak hanya membutuhkan teknologi. Namun demikian, ada juga hal lain yang perlu diketahui dan dilakukan sekalipun tanpa menggunakan teknologi. Contohnya, sebut saja pembelajaran akhlak dan budi pekerti. Bila pembelajaran dipenuhi dengan materi teori di kelas, hal itu jelas membosankan. Dalam hal ini, guru bisa menggunakan cara lain, misalnya pembelajaran lewat permainan. Siswa hendaknya dilibatkan dalam kegiatan ini. Bukan hanya 
asyik dan menyenangkan, tetapi siswa juga dapat belajar langsung dan pengalamannya.

\section{Ubah Mind Set, Prestasi Nggak Harus Mahal}

Kita sebagai manusia adalah makhluk yang paling special. Manusia dikaruniai akal oleh Allah Swt. sehingga dapat mengamati, berpikir, dan menyimpulkan. Dengan akal itulah manusia dapat mengembangkan ilmu sehingga sesuatu yang abstraic dapat menjadi konkret, sesuatu yang samar menjadi jelas dan sesuatu yang hanya mimpi dapat menjadi kenyataan. Bandingkan dengan hewan, hewan hanya bisa bergerak dengan insting, bukan dengan ilmu sehingga tidak dapat mengembangkannya. Selain itu, manusia memiliki insting dan imajinasi. Dengan intuisi dan imajinasilah manusia dapat meramal kejadian yang belum pernah terjadi. Imajinasinya dapat mendorong berbagai kreativitas sehingga menghasilkan sebuah karya.

Belum lagi lingkungan buruk sering meracuni hidup manusia. Satu contoh, di televisi, sangat mudah bagi kita menemukan tayangan-tayangan yang menutup inspirasi dan menenggelamkan kita pada khayalan-khayalan mistis yang membuat kita menjadi manusia lemah. Hal ini tentu saja secara langsung maupun tidak mempengaruhi penonton untuk tidak menggunakan rasio dalam berpikir, tidak menggunakan etika dalam berperilaku dan tidak menggunakan hati dalam memutuskan tindakan. Tidak hanya kita yang terpengaruh, tetapi teman, orangtua, dan saudara ikut terpengaruh. 
Dengan kondisi sekolah yang sangat memprihatinkan mereka tetap semangat mengajar. Mereka tetap mengajar meskipun atap sekolah bocor, papan tulis teLah berLubang, dan lantainya berupa tanah. Mereka tidak menggerutu karena dinding-dinding sekolah telah keropos dan bangunan yang hampir ambruk. Mereka juga tidak malu meskipun sekolahnya harus berutang kapur tulis untuk mengajar. Mereka mau mengajar meskipun dengan upah yang rendah dan suka telar dibayarkan.

Sekolah zaman now yang berkualitas merupakan idaman setiap pecinta pendidikan. Bayangkan apabila di suatu sekolah, setiap siswa begitu sangat dihargai sebagai insan anugerah Tuhan. Interaksi antara guru dan siswa diyakini sebagai faktor yang paling penting dalam perkembangan siswa. Para siswa dilayani sesuai dengan keistimewaannya masing-masing. Pola berpikir kritis dan berpikir global serta sikap hidup mandiri dikembangkan dalam setiap pembelajaran. Sementara itu, budayanya sangat kuat dalam memegang tradisi dan sejarah. Programprogramnya menyeimbangkan antara kegiatan akademis dan kegiatan ko-kurikuler. Siswa tidak dibiarkan liar begitu saja setelah jam sekolah sehingga tidak ada berita siswa tawuran setelah jam sekolah. Mereka diasramakan dengan programprogram asrama yang edukatif. Fasilitas sekolah yang digunakan adalah fasilitas yang paling mutakhir di zamannya, 
tetapi orangtua siswa tidak dipusingkan dengan mahalnya biasa pendidikan.

Guru dan karyawan memiliki kualifikasi tinggi dan berwawasan internasional. Sementara lulusannya cerus mengisi perguruan-perguruan terbaik di dunia. Mungkin pecinta pendidikan akan merasa bahagia karena tugas mulianya terlaksana dengan baik. Untuk meraih hal tersebut bukanlah pekerjaan yang mudah dan tentunya membutuhkan biaya yang tidak sedikir pula. Tetapi, optimisme terhadap impian itu pasti ada jika pengelola sekolah menerapkan prinsip Development Based Sustainable Growth atau pengembangan berbasis pertumbuhan berkelanjutan. Makna dan prinsip tersebut ialah sekolah dibangun secara bertahap berkelanjutan berdasarkan aspek kebutuhan dan kondisi internal. Perlu dipahami bahwa sekolah yang langsung dibangun secara besar-besaran tanpa mernerhatikan kebutuhan dan kondisi keuangan sekolah justru akan counterproductive karena biaya yang dikeluarkan tidak seimbang dengan produktivitas sekolah.

Meskipun pembangunan sekolah dilakukan secara bertahap, sekolah harus memiliki blueprint pengembangan yang jelas sebagai pedoman untuk mencapai tujuan akhir yang telah ditentukan. Harapannya ketika kepala sekolah telah berganti pun, pengembangan yang sesuai dengan konsep awal masih tetap dapat dilanjutkan. Bukan hanya pengembangan secara fisik seperti pembangunan gedung baru dan penambahan fasilitas saja, melainkan juga pengembangan sekolah secara nonfisik seperti peningkatan kualitas proses dan hasil belajar siswa. Oleh karena itu, ada 
dua hal yang penting dalam prinsip pengembangan sekolah berkelanjutan, yaitu konsep rumah turnbuh dan blueprint pengembangan sekolah.

\section{E. Konsep Rumah Tumbuh}

Rumah adalah istana keluarga. Setiap orang memimpikan rumah yang terbaik. Rumah yang dapat memberikan rasa nyaman, aman, dan tenteram bagi keluarga. Secara fisik banyak orang yang menginginkan rumah yang besar dan lengkap karena rumah merupakan tempat tinggal yang diharapkan dapat menghilangkan rasa penat seteiah seharian beraktivitas. Namun, banyak keluarga harus mengesampingkan mimpinya itu. Mereka harus berpikir ulang untuk memiliki rumah idaman karena kondisi keuangan yang tidak sepadan. Akibatnya, selera dan kualitas rumah menjadi terabaikan. Oleh karena itu, para arsitek menawarkan konsep rumah tumbuh sebagai solusinya. Konsep ini merupakan solusi untuk keluarga yang memiliki ekspektasi besar terhadap rumahnya, namun memiliki keterbatasan finansial. Sesuai dengan namanya, rumah tumbuh, berarti pembangunan rumah dilakukan secara bertahap dengan menyesuaikan keadaan ekonomi dan penambahan jumlah anggota keluarga. Rumah tumbuh dibangun secara berkesinambungan sesuai dengan desain awal. Tahapan pembangunan rumah mengikuti kebutuhan, kondisi keluarga, dan bagi penghuninya (Sholeh, 2018).

Demikian pula ketika masyarakat ingin membangun sebuah sekolah, konsep rumah tumbuh dapat diterapkan. Biasanya ketika masyarakat tertentu merasa sulit mengakses 
pendidikan atau merasa lembaga pendidikan yang ada tidak sesuai dengan apa yang diharapkan maka mereka mencoba merintis pendirian sebuah sekolah yang menurut mereka ideal. Sekolah yang akan dibangun bisa saja dibuat sesuai dengan sekolah yang ideal. Namun, apabila kondisi keuangan tidak mencukupi maka konsep rumah tumbuh dapat diterapkan sebagai solusinya. Sekolah dibangun secara bertahap, mengikuti perkembangan ekonomi sekolah. Hal yang terpenting adalah blueprint pembangunan sekolah harus sudah dibuat terlebih dahulu. Hal ini untuk menghindari bongkar pasang bangunan yang justru memperbesar pengeluaran.

Pembangunan sekolah dengan konsep rumah tumbuh dapat dilakukan secara vertikal maupun horizontal. Secara vertikal, berarti sekolah dikembangkan ke atas. Dalam mengembangkan bangunan ke atas, ada beberapa hal yang harus diperhatikan terkait dengan dengan fondasi, sloof, penggunaan besi tulangan, ring balok, atap sekolah, dan bentuk arsitektur. Pengembangan vertikal memerlukan fondasi sekolah yang kukuh untuk menopang bangunan yang terus bertambah sesuai dengan perencanaan.

Dalam sebuah organisasi, termasuk sekolah, blueprint sangat diperlukan untuk pengembangan sekolah secara berkelanjutan. Blueprint adalah rencana atau kerangka kerja arau rancangan yang sengaja dirumuskan sebagai pedoman dalam menjalankan aktivitas organisasi. Tujuan dan alokasi sumber daya merupakan dua kata kunci. Tujuan merupakan kondisi yang diinginkan sebuah organisasi di masa depan. 
Berdasarkan tìngkatannya ada tiga jenis tujuan, yaitu tujuan strategis, tujuan taktis, dan tujuan operasional. Tujuan strategis merupakan tujuan yang akan diraib dalam jangka panjang. Tujuan ini dicapai pada tingkat rencana strategis (strategic plan). Tujuan taktis dan tujuan operasional merupakan tujuan yang akan dicapai dalam jangka pendek. Tujuan-tujuan ini dicapai melalui rencana taktis (tactical plan) dan rencana operasional (operationalplan).

Manajemen

Puncak

(Tingkat Sekolah)

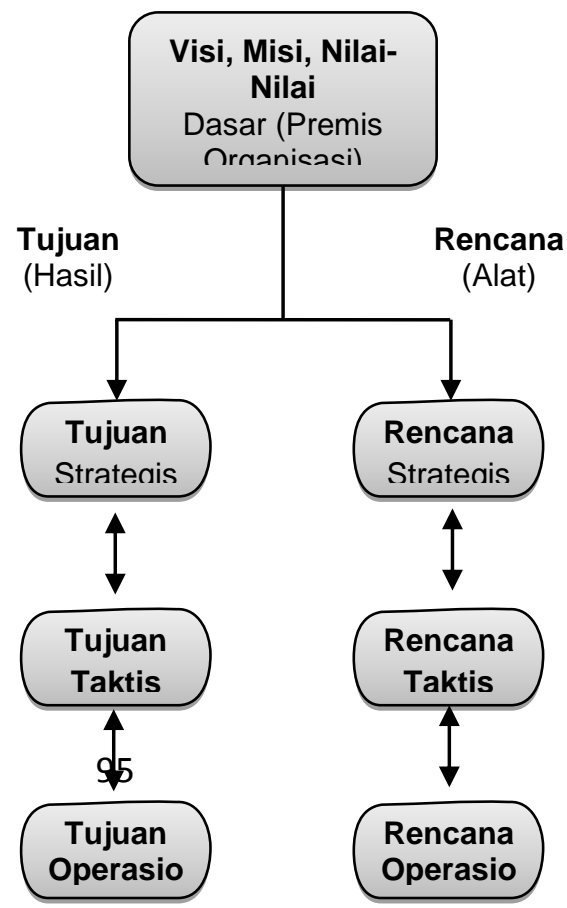

Manajemen Menengah

(Jurusan,

Program

Keahlian) 


\section{Gambar 13. Hubungan Antara Premis Tujuan dan Rencana}

Sumber: Depdiknas, Pendidikan dan Pelatihan: Perencanaan

Partisipatari

Pengembangan Pendidikan Berbasis Sekolah, (2007:18)

Dalam konsep pengembangan berbasis perrumbuhan berkelanjutan, diperlukan blueprint pengembangan yang jelas. Blueprint berisi ketetapan tentang apa yang ingin dicapai, apa, dan bagaimana cara melakukannya serta bagaimana cara mengetahui hasil yang dicapai. Blueprint dapat memperjelas tujuan dan strategi sehingga mernudahkan dalam membagi sumber daya. Selain itu, sekolah akan mudah dikembangkan tanpa harus mengorbankan banyak hal yang tidak seharusnya dikorbankan. Blueprint inilah yang telah membedakan antara hasil usaha seseorang dengan hasil usaha orang lain. Blueprint pulalah yang membedakan kecepatan suatu lembaga dalam rnengembangkan diri.

Dalam konteks persekolahan, blueprint pengembangan sekolah dikenal dengan istilah Rencana Pengembangan Sekolah (RPS). RPS dapat menjamin tercapainya tujuan dengan tingkat kepastian yang tinggi serta risiko yang kecil. Rencana pengembangan dapat mendukung koordinasi ancarpelaku sekolah, baik itu warga sekolah maupun 
masyarakat pemerhati pendidikan. Selain itu, RPS juga dapat mdnjamin terciptanya integrasi, sinkronisasi, dan sinergi, balk antarpelaku sekolah, antarsekolah dan Dinas Pendidikan kabupaten/ kota, dan antarwaktu. Meskipun berganti kepala sekolah, RPS akan menjadi pengait antarkegiatan sebelumnya dengan kegiatan yang akan datang sehingga program menjadi konsisten dan segi perencanaan, penganggaran, pelaksanaan, maupun pengawasannya. Aspek yang tidak kalah penting, RPS diharapkan dapat menjamin tercapainya penggunaan sumber-daya secara efisien, efektif, berkeadilan, dan berkelanjutan. Dokurnen RPS dapat dimanfaatkan sebagai dasar ketika melaksanakan monitoring dan evaluasi pada akbir program. RPS memuat hal apa yang akan dibangun di sekolah, bagaimana cara membangunnya, dan bagairnana melihat hasil pembangunan tersebut. Apa yang akan dibangun di sekolah termaktub dalam visi, misi, dan rujuan sekolah. Bagaimana cara membangunnya termaktuh dalam strategi yang digunakan, mulai dan penentuan kegiatan dan sasaran, pendanaan, sampai dengan penjadwalan. Selanjutnya, untuk mengetahui hasil capaian biasanya dilakukan melalui proses monitoring dan evaluasi.

\section{a. Perumusan Visi, Misi, dan Tujuan Sekolah}

Setiap organisasi tentunya membutuhkan arab yang jelas dalam upaya meningkatkan kualitas organisasinya. Dengan adanya arah yang jelas akan memantapkan langkah organisasi dalam menempuh jalan menuju mutu. Setiap organisasi membutuhkan acuan untuk menentukan kebijakan dan skala prioritas serta keberhasilan program. Oleh karena itu perumusan vlsi, 
misi, dan tujuan sekolah merupakan sesuatu hal yang amat penting dalam RPS.

Visi merupakan impian yang jelas di masa depan. Visi ditulis sebagai kata benda merupakan konsep masa depan yang ideal. Visi seharusnya singkat tetapi penuh dengan makna, filosofis tetapi mudah dipahami dan idealis tetapi dapat dicapai. Berdasarkan Permendiknas Nomor 19 Tahun 2007, Visi sekolah: (a) dijadikan sebagai cita-cita bersama warga sekolah dan segenap pihak yang berkepentingan pada masa yang akan datang; (b) mampu memberikan inspirasi, motivasi, dan kekuatan pada warga sekolah dan segenap pihak yang berkepentingan; (c) dirumuskan berdasar masukan dan berbagai warga sekolah dan pihak-pihak yang berkepentingan, selaras dengan visi institusi di atasnya serta visi pendidikan nasional; (d) diputuskan oLeh rapat dewan pendidik yang dipimpin oleh kepala sekolah dengan memerhatikan masukan komite sekolah; (e) disosialisasikan kepada warga sekolah dan segenap pihak yang berkepentingan; (f) ditinjau dan dirumuskan kembali secara berkala sesual dengan perkembangan dan tantangan di masyarakat. Untuk merumuskan visi yang balk, perlu diketahui ciri-ciri atau karakteristik visi yang efektif. Suatu visi dikatakan efektif jika memiliki karakteristik (Depdiknas, 2007: 37), sebagal berikut:

a. Jelas dan tidak membingungkan;

b. Menarik dan mudah diingat;

c. Aspiratif, realistis, dan dapat dicapai; 
d. Selaras dengan nilai-nilai, budaya, dan cara pandang sekolah;

e. Berjangka waktu;

f. Singkat, sebaiknya kurang dan sepuluh kata;

g. Inspiratifdan menantang;

h. Disepakati oleh semua stakebolder sekolah;

i. Menyatakan dengan jelas esensi dan apa yang seharusnya dicapai sekolah;

j. Fleksibel dan menumbuhkan kreativitas.

Misi merupakan alasan mengapa sebuah organisasi harus ada. Rumusan misi memuat pesan-pesan pokok tentang tujuan mendasar didirikannya suatu organisasi, niLai-nilai yang melandasi

pendirian dipertahankan/dipelihara. Misi organisasi harus sesuai dengan tugas pokok dan fungsi organisasi tersebut. Berdasarkan Permendiknas Nomor 19 Tahun 2007, misi sekolah: (a) memberikan arah dalam mewujudkan visi sekolah sesuai dengan tujuan pendidikan nasional; (b) merupakan tujuan yang akan dicapai dalam kurun waktu tertentu; (c) menjadi dasar program pokok sekolah; (d) menekankan pada kualitas layanan peserta didik dan mutu lulusan yang diharapkan oleh sekolah; (e) membuat pernyataan umum dan khusus yang berkaitan dengan program sekolah; (f) memberikan keluwesan dan ruang gerak pengembangan kegiatan satuan-satuan unit sekolah yang terlibat; (f) dirumuskan berdasarkan masukan dan segenap pihak yang berkepentingan termasuk komite sekolah dan diputuskan oleh rapat dewan pendidik yang dipimpin oleh kepala sekoLah; (g) 
disosialisasikan kepada warga sekolah dan segenap pihak yang berkepentingan; (9) ditinjau dan dirumuskan kembali secara berkala sesuai dengan perkembangan dan tantangan di masyarakat.

Untuk merumuskan misi yang baik, perlu dipahami ciricirinya. Misi yang baik memiliki karakteristik, yakni memuat seluruh makna yang terkandung dalam visi, memberikan petunjuk atas tujuan yang akan dicapai dan kelompok sasaran, memperhitungkan masukan dan stakeholders, fokus pada kemampuan yang dimiliki sekolah dan bebas dan kata-kata yang tidak bermakna.

Visi dan misi perlu ditelaah validitas dan relevansinya. Berikut ini sejumlah pertanyaan yang dapat dijadikan instrumen untuk menelaah validitas dan relevansi visi misi sekolah.

a. Aspek-aspek mana dan rumusan vlsi dan misi yang ada masih relevan?

b. Dalam kaitannya dengan kebutuhan akan perubahan masyarakat yang berlangsung saat ini, apa yang perlu diperbarui, ditambahkan, atau dihilangkan dan rumusan visi dan misi tersebut?

c. Bagaimana visi dan misi tersebut dapat dipertahankan dalam masyarakat sekolah?

d. Sejauhmana kebijakan dan dokumentasi sekolah mencerminkan visi dan misi tersebut?

e. Sejauhmana kurikulum merefleksikan nilai-nilai yang rerkandung dalam visi dan misi sekolah? 
f. Sejauhmana manajemen sekolah merefleksikan nilainilai dan keyakinan yang dinyatakan dalam rumusan visi dan misi?

g. Sejauhmana hubungan di lingkungan internal sekolah dan antara berbagai pihak di kalangan warga sekolah merefleksikan rumusan visi tersebut?

h. Sejauhmana rumusan vlsi dan misi merefleksikan kebutuhan sebuah masyarakat multikultural yang kompleks?

Tujuan yang diturunkan langsung dan misi memberikan gambaran secara umum, tidak mengenal batas waktu dan bersifat relatif. Depdiknas (2007: 39), memaknai tujuan sekolah sebagai pernyataan umum rentang tujuan pendidikan di sekolah itu. Tujuan tujuan itu harus berkait dengan usaha mendorong perkembangan semua peserta didik balk secara intelektual, fisikal, sosial, personal, spiritual, moral, kinestetikal, maupun estetikal. Tujuan sekolah harus dirumuskan dalam kerangka visi dan misi sekolah. Aspirasi semua stakebolder harus terwadahi dalam konteks yang lebih luas dan rumusan visi dan misi sekolah.

Dalam merumuskan tujuan sekolah hendaknya: (a) menggambarkan tingkat kualitas yang perlu dicapai dalam jangka menengah (empat rahunan); (b) mengacu pada visi, misi, dan tujuan pendidikan nasional serta relevan dengan kebutuhan masyarakat; (c mengacu pada standar kompetensi lulusan yang sudah ditetapkan oleh sekolah dan Pemerintah; (d) mengakomodasi masukan dan berbagai pihak yang berkepentingan 
termasuk komite sekolah dan diputuskan oleh rapat dewan pendidik yang dipimpin oleh kepala sekolah; (e) disosialisasikan kepada warga sekolah dan segenap pihak yang berkepentingan (Permendiknas No. 19 Tahun 2007).

Tujuan sekolah yang memiliki peluang untuk dicapai adalah tujuan yang memiliki ciri keefektifan. Karakteristik tujuan yang efektif (Depdiknas, 2007: 4445), sebagai berikut.

a. Spesifik dan Terukur. Jika dimungkinkan sedapat mungkin tujuan dirumuskan dalam terminologi kuantitatif. Apabila rujuan sulit atau tidak dapat dinyatakan dalam rumusan yang bersifat kuantitatif, rumusan tujuan dapat dinyatakan secara kualitatif. Akan tetapi, apabila ini dilakukan, rumusan tujuan hendaknya disertai indikatorindikator yang spesifik dan bersifat kuantitatif.

b. Mencakup dimensi-dimensi kunci. Tujuan strategis tidak mungkin dirumuskan secara rinci untuk setiap unsur terkecil dan organisasi sekolah. Di sekolah dimensi-dimensi kunci itu dapat dibedakan menurut fungsi-fungsi organisatoris sekolah atau ranah kompetensi atau kualifikasi lulusan. Dan sisi fungsi organisatoris sekolah dimensi-dimensi kunci itu dapat dibedakan menjadi kurikulum, kesiswaan, atau kerja sama dengan masyarakat. Sementara dan dimensi ranah kompetensi lulusan, dimensidimensi kunci tersebut dapat dibedakan menjadi kompetensi intelektual, kompetensi moral dan 
spiritual, kompetensi sosial, kompetensi personal, kompetensi estetikal, dan kompetensi estetikal.

c. Menantang tapi realistis. 1iijuan harus mcnanrang, namun bukan berarti terlalu sulit untuk dicapai. Tujuan yang terlalu sulk dapat berdampak pada timbulnya keputus-asaan di kalangan staf, tapi jika terlalu rnudah para staf itu akan kurang termotivasi. Rurnusan tujuan strategis hendaknya terjamin bahwa tujuan itu dirurnuskan dalam lingkup sumber daya yang tersedia dan tidak jauh di luar jangkauan sumber daya yang tersedia di sekolah, baik yang berkaitan dengan waktu, SDM, sarana dan prasarana, keuangan, informasi, maupun teknologi.

d. Dibatasi dalam kurun waktu tertentu. Rurnusan tujuan harus menetapkan jangka waktu pencapaiannya. Kurun waktu itu biasanya dijadikan batas waktu mengenai kapan pencapalan rujuan tersebut akan diukur.

e. Terkait dengan imbalan atau ganjaran. Dampak akhir dan tujuan bergantung pada sejauhmana peningkatan gaji, prornosi, dan imbalan lainnya didasarkan pada prestasi terkait dengan pencapaian tujuan. Siapa saja yang berhasil mencapai tujuan harus mendapatkan ganjaran. Ganjaran dapat memberi makna dan signifikansi terhadap tujuan dan akan membantu memberikan suntikan energi kepada staf untuk berlomba-lomba mencapai tujuan. 


\section{b. Pemetaan Kondisi dan Perumusan Harapan Sekolah}

Hal pertarna yang harus dilakukan untuk membuat RPS ialah mengevaluasi kondisi sekolah. Evaluasi ini dilakukan dengan cara menilai diri sendiri atas apa yang telah diraih saat ini untuk mengetahui sejauhmana kualitas suatu sekolah. Penilaian diri dilakukan dengan cara mempelajari data-data di sekolah, mengamati sekolah dengan saksama, ataupun meminta tanggapan kepada stakeholders.

Evaluasi diri dapat memberikan manfaat hagi pemerintah ataupun bagi sekolah itu sendiri. Bagi pemerintah, hasil evaluasi diri sekolah berrnanfaat sebagai data dan informasi yang penting dan akurat untuk perencanaan, pembuatan kebijakan dan penganggaran.

Selain itu, dengan adanya evaluasi din pernerintah dapat memahami hal apa saja yang harus diprioritaskan untuk memenuhi kebutuhan sekolah. Sementara ini, evaluasi diri bagi sekolah bermanfaat untuk mengidentifikasi kelebihan serta kekurangan din sendiri dan untuk merencanakan pengembangan sekolah ke depan. Dengan dernikian, hasil evaluasi din dapat digunakan sehagai alat untuk "bercermin". Dari hasil evaluasi diri pula, sekolah dapat menemukan peluang untuk meningkatkan mutu pendidikan.

Apa saja yang hartis dievaluasi sangat bergantung pada kebutuhan tiap-tiap sekolah. Sekolah sani dengan sekolah yang lain rnungkin berbeda kebutuhannya. Oleh 
karena itu, tidak bisa disamakan struktur evaluasi atau format evaluasinya. Meskipun demikian (Depdiknas, 2007: 50), komponen-komponen pokok berikut harus tercantum dalam evaluasi diri.

a. Analisis lingkungan eksternal yang dimaksudkan untuk mengindentifikasi peluang dan ancaman yang dihadapi sekolah. Analisis dilakukan terhadap kondisi dan situasi di luar sekolah, baik di tingkat lokal, nasional maupun internasional. Aspek-aspek yang dievaluasi terkait dengan kecenderungan perubahan (ideologi, politik. kultur, budaya, ilmu pengetahuan, dan sistem pendidikan), kebutuhan stakeholders dan pasar kerja (industri, masyarakat, pernenintah dan kemungkinan bagi lulusan untuk menciptakan pasar kerja).

b. Evaluasi kegiatan pendidikan dan pembelajaran. Aspek-aspek yang dievaluasi meliputi kekuatan dan/atau kelemahan lulusan, siswa, kurikulum, proses pembelajaran, kegiatan ekstrakurikuler, pembangunan karakter, program layanan khusus, dan lain sebagainya.

c. Evaluasi sumber daya pendidikan. Sumber daya yang dievaluasi meliputi sumber daya manusia (pendidik dan tenaga kependidikan), sarana prasarana sekolah, sistern informasi, dan keuangan.

Manajemen dan kepemimpinan sekolah. Aspek-aspek yang dievaluasi meliputi organisasi dan tata kelola sekolah, kepemimpinan serta budaya dan ikiim sekolah. Dengan adanya evaluasi diri, kondisi sekolah dapat 
dipetakan. Selanjutnya, sekolah dapat menentukan harapan-harapannya terkait dengan kondisi sekolah yang ada. Tetapi yang perlu diperhatikan adalah harapan sekolah harus dibandingkan dengan standar sekolah yang berkualitas. Indikator standar sekolah yang berkualitas dapat mengacu pada peraturan pemerintah tentang standar nasional pendidikan. Dengan begitu akan kelihatan apakah harapan yang ditentukan masih di bawah standar, mencapai standar, atau di atas standar. Berikut ini contoh format pemetaan kondisi dan harapan sekolah.

Tabel 2. Pemetaan kondisi dan Harapan Sekolah

\begin{tabular}{|c|c|c|c|}
\hline \multicolumn{2}{|c|}{ Komponen } & \multicolumn{1}{c|}{ Kondisi } & \\
\hline I & a. & & \\
& b. & & \\
\hline 2 & a. & & \\
\hline & b. & & \\
\hline
\end{tabular}

\section{c. Pemetaan Kesenjangan}

Setelah kondisi nyata sekolah dan harapan sekolah selesai dirurnuskan, langkah selanjutnya ialah memetakan kesenjangan. Caranya ialah dengan membandingkan antara kondisi nyata dengan harapan. Gap antara keduanya merupakan kesenjangan atau masalah yang harus diatasi. Berangkat dan masalah yang muncui kemudian dicari akar permasalahannya kemudian dicari alternatif pemecahan masalahnya. Alternatif pemecahan masalah akan sangat baik apabila lebih dan satu. 
Tabel 3. Pemetaan Kesenjangan

\begin{tabular}{|l|l|l|}
\hline \multicolumn{1}{|l|}{ Kesenjangan } & \multicolumn{1}{c|}{ Penyebab } & Alternatif Pemecahan \\
\hline 1. & a. & \\
\cline { 3 - 3 } & & \\
\hline & b. & \\
\hline 2. & a. & \\
\cline { 3 - 3 } & & \\
\hline & b. & \\
\hline
\end{tabular}

\section{d. Pemetaan Alternatif Pemecahan Masalah}

Sejumlah alternatif pemecahan masalah yang telah dibuat kemudian dianalisis dan sisi kekuatan maupun kelemahannya. Alternatif pemecahan masalah diidentifikasi dan sisi kelebihannya dan kekurangannya untuk mengetahui alternatif pemecahan mana yang paling balk. Dengan adanya pernetaan seperti itu diharapkan solusi yang diambil merupakan solusi yang paling tepat.

\section{Pemilihan Prioritas Kegiatan}

Pemecahan masalah yang telah diambil kemudian dibuat skala prioritas waktu pelaksanaan. Pemecahan masalah diurai menjadi beberapa kegiatan. Kegiatan rersebut kemudian dipilih mana yang perlu didahulukan dan mana yang dapat ditunda pelaksanaannya. Pernbagiannya berdasarkan skala prioritas jangka pendek, jangka menengah, dan jangka panjang. Cara 
pemilihan prioritasnya ialah engan cara menuliskan semua alternatif pemecahan masalah dalam bentuk program ke dalam kolorn program, semua kegiatan ditulis dalam kolom kegiaran sesuai dengan programnya, dan skala prioritas diberi warna pada kolom jangka pendek, jangka menengah, atau jangka panjang.

Setelah itu, dituliskan alasan mengapa suatu kegiatan diletakkan pada skala prioritas tertentu. Penulisan alasan skala prioritas sangat penting dilakukan dalarn upaya mendukung transparasi dan akuntabilitas penyusunan RPS.

\section{e. Penjadwalan Kegiatan}

Setelah penentuan prioritas kegiatan ditentukan maka langkah selanjutnya ialah membuat jadwal kegiatan. Jadwal kegiatan memuat program, kegiaran. dan pelaksanaan di setiap bulannya. Program dan kegiaran disusun secara berurutan berdasarkan skala prioritas. Pada kolom waktu pelaksanaan dibuat grafik diagram batang yang memanjang secara horizontal. Berikut ini contoh format penjadwalan kegiatan RPS.

Tabel 4. Format Rincian Jadwal Pelaksanaan

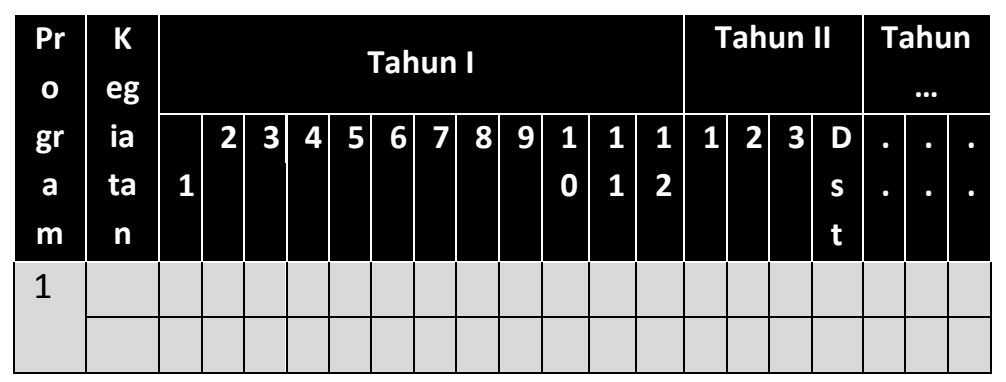




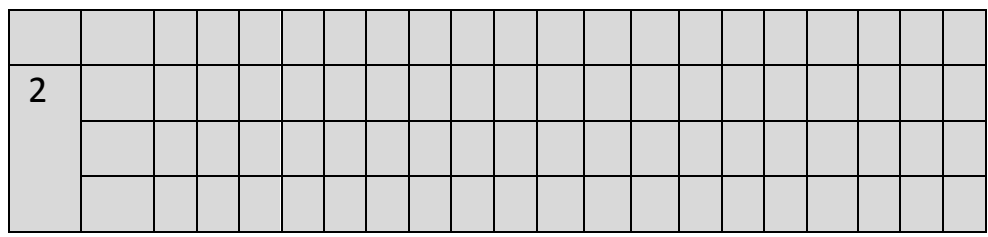

\section{f. Perhitungan Anggaran Biaya}

Pekerjaan yang tidak boleh terlupakan saat pembuatan RPS ialah menghitung anggaran biaya. Perhitungan anggaran biaya sangat diperlukan untuk mengetahui seberapa besar kebutuhan dana yang harus dipenuhi. Perhitungan anggaran biaya dibuat secara teperinci yang mana di dalamnya mernuat volume kegiatan, harga persatuan rupiah, jumlah harga, dan sumber dana. Untuk menghitung volume suatu pekerjaan biasanya dilakukan dengan cara mengalikan jumlah orang, jumlah hari kerja dan jumlah jam kerja. Contoh format perhitungan anggaran biaya dapat dilihat pada tabel berikut ini.

Tabel 5. Format Perhitungan Anggaran Biaya

\begin{tabular}{|l|l|l|l|l|}
\hline \multicolumn{2}{|c}{ Kegiatan } & \multicolumn{4}{c}{$\begin{array}{c}\text { Harga } \\
\text { Volume }\end{array}$} & $\begin{array}{c}\text { Jumlah } \\
\text { Satuan } \\
\text { (Rp.) }\end{array}$ & $\begin{array}{c}\text { Baya } \\
\text { (Rp) }\end{array}$ & $\begin{array}{c}\text { Sumber } \\
\text { Dana }\end{array}$ \\
\hline & & & & \\
\hline & & & & \\
\hline
\end{tabular}


Dalam menyusun rencana keuangan sekolah, termasuk perhitungan anggaran biaya, ada beberapa hal yang perlu diperhatikan (Depdiknas, 2008b: 44-45), yaitu:

a. Perencanaan harus realistis. Perencanaan harus mampu menilai bahwa alternatif yang dipilih sesuai dengan kemampuan sarana/ fasilitas, daya/tenaga, dana maupun waktu.

b. Perlunya koordinasi dalam perencanaan. Perencanaan harus mampu memerhatikan cakupan dan sarana volume kegiatan sekolah yang kompleks.

c. Perencanaan harus berdasarkan pengalarnan, pengetahuan, dan intuisi. Pengalaman, pengetahuan, dan intuisi mampu menganalisis berbagai kemungkinan yang terbaik dalam menyusun perencanaan.

d. Perencanaan harus fleksibel. Perencanaan mampu menyesuaikan dengan segala kemungkinan yang tidak diperhatikan sebelumnya tanpa harus membuat revisi.

e. Perencanaan yang didasarkan penelitian. Perencanaan yang berkualitas perlu didukung data yang lengkap dan akurat melalui suatu penelitian.

f. Pcrencanaan sesuai dengan tujuan. Perencanaan yang baik akan menentukan mutu kegiatan-kegiatan yang diselenggarakan.

\section{h. Alternatif Pendanaan}

Perencanaan sebaik apa pun tidak akan terlaksana dengan baik apabila tanpa dukungan dana. Hal ini sangat 
penting untuk dipikirkan dengan sungguh-sungguh karena setiap kegiatan akan lumpuh jika tanpa ada pendanaan. Biasanya sekolah selalu menerima dana rutin dan pemerintah atau yayasan. Meskipun demikian, sekolah tidak boleh hanya bergantung pada sumber dana itu. Tetapi, perlu dicarikan sumber dana lain yang dapat menopang program sekolah. Sumber dana lain yang potensial, misalnya usaha mandiri sekolah, sumbangan donatur, sumbangan alumni, atau kerja sama saling menguntungkan antaran sekolah dengan lembaga lain.

Apabila pendanaan sekolah hanya diusahakan oleh kepala sekolah saja maka kemungkinan dana yang diperolehnya relatif kecil. Hal tersebut akan berbeda jika usaha pencarian dana melibatkan sejumlah pihak yang potensial. Sekolah dapat bekerja sama dengan komite sekoLah, alumni, Lembaga Swadaya Masyarakat (LSM) yang peduli pendidikan, lembaga donor internasional, atau pihak-pihak lain yang memiliki komitmen untuk memajukan pendidikan.

Tabel 6. Format Pemetaan Alternatif Pemecahan Masalah

\begin{tabular}{|l|l|l|l|}
\hline \multicolumn{1}{|c|}{ Sumber Dana } & $\begin{array}{c}\text { Penggunaan } \\
\text { Dana }\end{array}$ & $\begin{array}{c}\text { Alternatif } \\
\text { Penggalian } \\
\text { Dana }\end{array}$ & Pelaksana \\
\hline 1. APBN & & & \\
\hline 2. APBD Provinsi & & & \\
\hline $\begin{array}{l}\text { 3. APBD } \\
\text { Kota/Kabupate } \\
n\end{array}$ & & & \\
\hline
\end{tabular}




\begin{tabular}{|l|l|l|l|}
\hline $\begin{array}{l}\text { 4. Komite } \\
\text { Sekolah }\end{array}$ & & & \\
\hline 5. Yayasan & & & \\
\hline 6. Donatur & & & \\
\hline $\begin{array}{l}\text { 7. Usaha Mandiri } \\
\text { Sekolah }\end{array}$ & & & \\
\hline 8. Lain-lain & & & \\
\hline
\end{tabular}




\section{KESIMPULAN}

Sekolah zaman now yang berkualitas merupakan idaman setiap pecinta pendidikan. Bayangkan apabila di suatu sekolah, setiap siswa begitu sangat dihargai sebagai insan anugerah Tuhan. Interaksi antara guru dan siswa diyakini sebagai faktor yang paling penting dalam perkembangan siswa. Para siswa dilayani sesuai dengan keistimewaannya masing-masing. Pola berpikir kritis dan berpikir global serta sikap hidup mandiri dikembangkan dalam setiap pembelajaran

Menjadi guru masa kini juga harus supel, lucu, dan tidak mudah emosi dalam menghadapi peserta didik di kelas. Kalaupun ada peserta didik yang nakal, usahakan jangan terpancing amarah. Justru, kita harus bisa menahan emosi dan memberikan nasihat secara lembut kepada peserta didik yang bersangkutan. Kids zaman now tidak menyukai kekakuan, terutama guru yang hanya memedulikan penyampaian materi tanpa memikirkan tingkat kepahaman peserta didiknya. 


\section{SOAL-SOAL}

1. Bagaimana tips menjadi guru ideal masa kini?

2. Bagaimana menjadikan pendidik sebagai guru kreatif millennial?

3. Bagaimana menerapkan system punishment dalam pembelajaran sekolah unggul?

4. Bagaiimana guru dan siswa menyikapi reward dalam pembelajaran sekolah unggul?

5. Bagaimana memetakan kondisi dan merumuskan harapan sekolah menuju sekolah unggul? 


\section{DAFTAR PUSTAKA}

Agbarachi Opara, J., \& Silas Oguzor, N. (2011). Inquiry Instructional Method and the School Science Currículum. Current Research Journal of Social Sciences, 3(3), 188-198.

Atif, Y., Mathew, S. S., \& Lakas, A. (2015). Building a smart campus to support ubiquitous learning. Journal of Ambient Intelligence and Humanized Computing, $6(2), \quad 223-238$. https://doi.org/10.1007/s12652014-0226-y

Chin, K.-Y., \& Chen, Y.-L. (2013). A Mobile Learning Support System for Ubiquitous Learning Environments. Procedia - Social and Behavioral Sciences, 73, 1421. https://doi.org/10.1016/j.sbspro.2013.02.013

Fahyuni, E. (2018). Bimbingan Konseling Islami di Sekolah (1 ed.). Sidoarjo: Umsida Press.

Maoto, S. (2014). Creating a child friendly psychosocial learning environment in mathematics: A case of problem solving in grade 6. Mediterranean Journal of Social Sciences, 5(23), 1048-1055. https://doi.org/10.5901/mjss.2014.v5n23p1048

Nuraeni, L., Andrisyah, A., \& Nurunnisa, R. (2019). Efektivitas Program Sekolah Ramah Anak dalam Meningkatkan Karakter Anak Usia Dini. Jurnal Obsesi : Jurnal Pendidikan Anak Usia Dini, 4(1), 20. https://doi.org/10.31004/obsesi.v4i1.204

Claessens, L. C. A., van der Want, A. C., \& van Tartwijk, J. (2018). Interpersonal adaptation in teacherstudent interaction. Learning and Instruction, 55, 41-57.

https://doi.org/10.1016/j.learninstruc.2017.09.005 


\section{DAFTAR PUSTAKA}

Agbarachi Opara, J., \& Silas Oguzor, N. (2011). Inquiry Instructional Method and the School Science Currículum. Current Research Journal of Social Sciences, 3(3), 188-198.

Aritonang, S. D., Hastuti, D., \& Puspitawati, H. (2020). Pengasuhan Ibu, Keterlibatan Ayah Dalam Pengasuhan, dan Perkembangan Kognitif Anak Usia 2-3 Tahun di Wilayah Prevalensi Stunting. Jurnal IImu Keluarga \& Konsumen, 13(1), 38-48.

Atif, Y., Mathew, S. S., \& Lakas, A. (2015). Building a smart campus to support ubiquitous learning. Journal of Ambient Intelligence and Humanized Computing, 6(2), 223-238. https://doi.org/10.1007/s12652-014-0226-y

Chin, K.-Y., \& Chen, Y.-L. (2013). A Mobile Learning Support System for Ubiquitous Learning Environments. Procedia - Social and Behavioral Sciences, 73, 14-21. https://doi.org/10.1016/j.sbspro.2013.02.013

Çobanoğlu, F., Ayvaz-Tuncel, Z., \& Ordu, A. (2018). Childfriendly schools: An assessment of secondary schools. Universal Journal of Educational Research, 6(3), 466477. https://doi.org/10.13189/ujer.2018.060313

Fahyuni, E. (2018). Bimbingan Konseling Islami di Sekolah (1 ed.). Sidoarjo: Umsida Press.

Fariyatul, E., \& Bandono, A. (2017). The use of value clarification technique-based- picture story media as an alternative media to value education in primary school. Harmonia: Journal of Arts Research and Education, 17(1), 68.

https://doi.org/10.15294/harmonia.v17i1.7469

Hermino, A. (2017). Child-Friendly School in Educational 
Settings for Elementary School in the Papua Island of Indonesia. Global Journal of HUMAN-SOCIAL SCIENCE: G Linguistics \& Education, 17(1), 48-60.

Leino, M. (2011). The child friendly school: an idea versus reality. Problems of education in the 21st century, 29, 82-88.

Lin, Y. (2012). Adopting Creative Pedagogy into Asian Classrooms? -Case Studies of Primary School Teachers' Responses and Dilemma. Journal of Education and Learning, 1(2), 205-216. https://doi.org/10.5539/jel.v1n2p205

Maisari, S., \& Purnama, S. (2019). Peran Digital Parenting Terhadap Perkembangan Berpikir Logis Anak Usia 5-6 Tahun Di Ra Bunayya Giwangan. AWLADY: Jurnal Pendidikan Anak, $5(1)$, 41. https://doi.org/10.24235/awlady.v5i1.4012

Maoto, S. (2014). Creating a child friendly psychosocial learning environment in mathematics: A case of problem solving in grade 6. Mediterranean Journal of Social Sciences, 5(23), 1048-1055. https://doi.org/10.5901/mjss.2014.v5n23p1048

Mouri, Kousuke; Uosaki, Noriko; Ogata, H. (2018). Learning Analytics for Supporting Seamless Language Learning using E- book with Ubiquitous Learning System. Educational Technology \& Society, 21(2), 150-163. https://doi.org/10.1007/springerreference_226192

Nuraeni, L., Andrisyah, A., \& Nurunnisa, R. (2019). Efektivitas Program Sekolah Ramah Anak dalam Meningkatkan Karakter Anak Usia Dini. Jurnal Obsesi : Jurnal Pendidikan Anak Usia Dini, 4(1), 20. https://doi.org/10.31004/obsesi.v4i1.204

Orkodashvili, M. (2013). Quality Education through ChildFriendly Schools: Resource Allocation for the Protection 
of Children's Rights. SSRN Electronic Journal, 5(1), 101109. https://doi.org/10.18662/rrem/2013.0501.07

Pennings, H. J. M., Brekelmans, M., Sadler, P., Claessens, L. C. A., van der Want, A. C., \& van Tartwijk, J. (2018). Interpersonal adaptation in teacher-student interaction. Learning and Instruction, 55, 41-57. https://doi.org/10.1016/j.learninstruc.2017.09.005

Purwati, N., Zubaidah, S., Corebima, A. D., \& Mahanal, S. (2018). Increasing Islamic Junior High School students learning outcomes through integration of science learning and Islamic values. International Journal of Instruction, 11(4), 841-854. https://doi.org/10.12973/iji.2018.11453a

RI, K. A. (2012). Al Qur'an Terjemah (T. S. Qur'an, ed.). Bandung: Syaamil Qur'an.

Saat, S. (2010). Pendidikan Anak Dalam Al Qur'an. Lentera Pendidikan, 13(1), 64-77.

Setyastuti, Y., Suminar, J. R., Hadisiwi, P., \& Zubair, F. (2019). Millennial moms: Social media as the preferred source of information about parenting in Indonesia. Library Philosophy and Practice, 2019.

Sholeh, M. (2018). Pendidikan Anak Usia Dini Dalam Perspektif Pendidikan Islam. YINYANG: Jurnal Studi Islam, Gender dan Anak, 13(1), 71-83. https://doi.org/10.24090/yinyang.v13i1.2018.pp71-83

Wadjdy, F. (2017). Education in Border Regions. TARBIYA: Journal of Education in Muslim Society, 4(2), 224-231. https://doi.org/10.15408/tjems.v4i2.6982

Zendah, K. (2018). Exploring School-Based Stakeholder Support for Teachers in the Promotion of Child-Friendly School Environments Abstract: International Journal of Innovative Research \& Development, 7(6), 162-171. 


\section{BIODATA PENULIS BIODATA PENULIS}

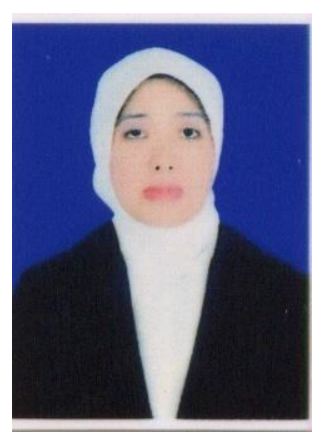

Dr. Eni Fariyatul Fahyuni, M.Pd.I lahir di Sidoarjo, 04 November 1978. Lulus Sarjana Psikologi Universitas Islam Negeri Surabaya tahun 2011, melanjutkan studi S2 di Prodi Pendidikan Islam Program Pascasarjana Universitas Muhammadiyah Sidoarjo lulus tahun 2013. Lulus program Doktor di Prodi Teknologi Pendidikan Program Pascasarjana Universitas Negeri Surabaya tahun 2018. Penulis terlibat aktif dalam penelitian dan pengabdian kepada masyarakat baik didanai oleh Ristekdikti maupun dana mandiri terkait pengembangan media dan desain pembelajaran inovatif.

Dr. Nurdyansyah, M.Pd. dilahirkan di Kediri, 12 Maret 1985. Lulus S-1 UIN, Maliki Malang dan melanjutkan studi S2 PGMI UIN, Maliki Malang. Lulus S3 Program Doktor di prodi Teknologi Pendidikan Program Pascasarjana Universitas Negeri Surabaya tahun 2019. Sosok yang dikenal energik dan

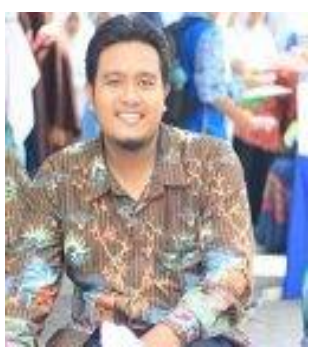
murah senyum ini juga mengembangkan kemampuan di bidang editor dan terlibat dalam penelitian dan pengabdian kepada masyarakat baik didanai oleh Ristekdikti maupun dana mandiri tentang pengembangan media dan desain pembelajaran inovatif. 